\title{
FACTORS THAT CONTRIBUTE TO OPEN SOURCE SOFTWARE PROJECT SUCCESS
}

\author{
by \\ Rizwan Ur Rehman \\ A thesis submitted to the Faculty of Graduate Studies and Research \\ in partial fulfillment of the requirements for the degree of \\ Master of Engineering in Telecommunications Technology Management
}

\author{
Department of Systems and Computer Engineering \\ Carleton University \\ Ottawa, Canada, K1S 5B6
}

April, 2006

(C) Copyright 2006 Rizwan Ur Rehman 


$\begin{array}{ll}\begin{array}{l}\text { Library and } \\ \text { Archives Canada }\end{array} & \begin{array}{l}\text { Bibliothèque et } \\ \text { Archives Canada }\end{array} \\ \begin{array}{l}\text { Published Heritage } \\ \text { Branch }\end{array} & \begin{array}{l}\text { Direction du } \\ \text { Patrimoine de l'édition }\end{array} \\ \begin{array}{l}\text { 395 Wellington Street } \\ \text { Ottawa ON K1A ON4 }\end{array} & \begin{array}{l}\text { 395, rue Wellington } \\ \text { Ottawa ON K1A ON4 } \\ \text { Canada }\end{array}\end{array}$

Your file Votre référence ISBN: 978-0-494-16486-0 Our file Notre référence ISBN: 978-0-494-16486-0

NOTICE:

The author has granted a nonexclusive license allowing Library and Archives Canada to reproduce, publish, archive, preserve, conserve, communicate to the public by telecommunication or on the Internet, loan, distribute and sell theses worldwide, for commercial or noncommercial purposes, in microform, paper, electronic and/or any other formats.

The author retains copyright ownership and moral rights in this thesis. Neither the thesis nor substantial extracts from it may be printed or otherwise reproduced without the author's permission.
AVIS:

L'auteur a accordé une licence non exclusive permettant à la Bibliothèque et Archives Canada de reproduire, publier, archiver, sauvegarder, conserver, transmettre au public par télécommunication ou par l'Internet, prêter, distribuer et vendre des thèses partout dans le monde, à des fins commerciales ou autres, sur support microforme, papier, électronique et/ou autres formats.

L'auteur conserve la propriété du droit d'auteur et des droits moraux qui protège cette thèse. $\mathrm{Ni}$ la thèse ni des extraits substantiels de celle-ci ne doivent être imprimés ou autrement reproduits sans son autorisation.
In compliance with the Canadian

Privacy Act some supporting forms may have been removed from this thesis.

While these forms may be included in the document page count, their removal does not represent any loss of content from the thesis.
Conformément à la loi canadienne sur la protection de la vie privée, quelques formulaires secondaires ont été enlevés de cette thèse.

Bien que ces formulaires aient inclus dans la pagination, il n'y aura aucun contenu manquant.

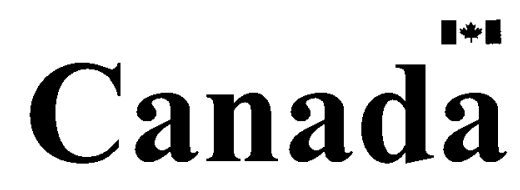




\begin{abstract}
This research examines the factors that contribute to the success of open source software projects. Examination of 70 replies from software developers led to the identification of the two measures of project success used in this research: number of downloads and number of releases. The multivariate general linear model was used to examine data from a sample comprised of 350 open source software projects and a sub-sample comprised of 108 production/stable and mature projects. Results suggest that: i. developers who contribute to open source projects define project success in ways not traditionally used to measure the success of product development projects, ii. the most successful open source projects are those that develop application development and deployment tools, attract a greater number of experienced developers, and target users who are developers, iii. use of commonly used programming languages and non-restrictive software licenses does not significantly affect open source project success, iv. production/stable and mature open source projects that develop application development and deployment tools are more successful than projects that develop application and system infrastructure software, and v. development status affects the factor-success relationship for open source projects.
\end{abstract}




\section{ACKNOWLEDGEMENTS}

First of all I am thankful to almighty ALLAH SUBHANAWATALA who helped me to accomplish this task.

This thesis was developed as part of the Competing in open environments research program led by Tony Bailetti, Carleton University, and Peter Carbone, Nortel. The support received from Nortel for this research and the M.Eng. in Telecommunications Technology Management Program is gratefully acknowledged.

I am deeply grateful to my thesis supervisor Professor Tony Bailetti for his dedication, stimulating suggestions, and tireless guidance in the various stages of preparing this thesis. He taught me how to express my ideas and showed different ways to approach a research problem.

I would like to thank Professor John Callahan for his constructive suggestions, support, and ideas for improvement of this study throughout the program.

I would like to thank Tanvir Ahmad, Senior Executive Vice President Operations, Shahid Pervaiz Noor, General Manager Operations, and Muhammad Aslam Baluch, Senior Manager Establishment of Pakistan Telecommunications Company Limited, Pakistan for their support during my leave from the company. 
I thank my mother, Mrs. Bilqees Jamal, for her never ending prayers and her motivation in my continuous struggles. I thank my friends because of their support during this task. Last, but not least, I am thankful to my wife Rehana and my sons Rohan and Erhan for their continuing support and understanding during the completion of my graduate program.

I name this document to my late father, Muhammad Farooq Ahmed, who is my role model. 


\section{TABLE OF CONTENTS}

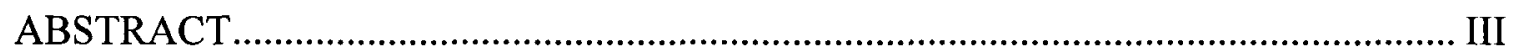

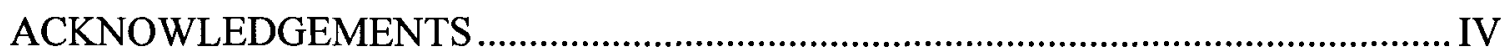

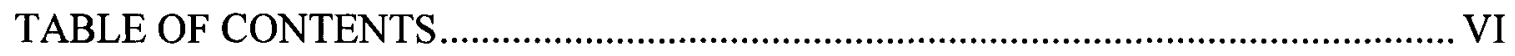

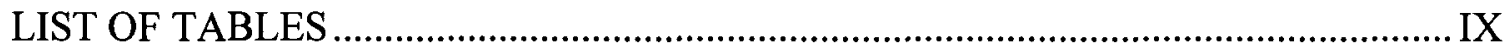

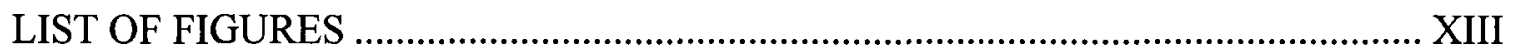

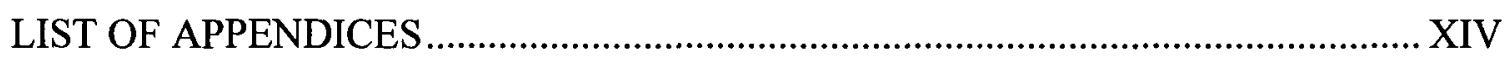

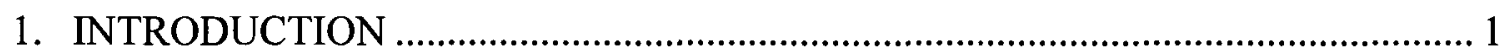

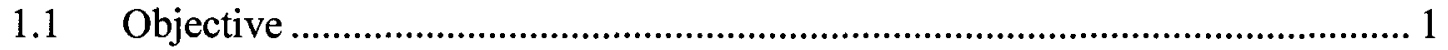

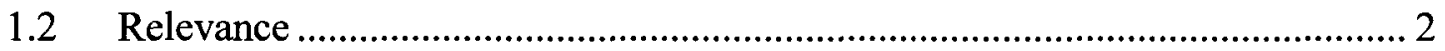

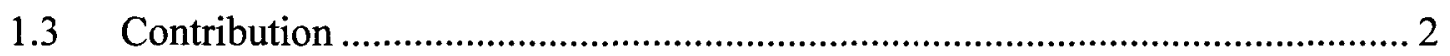

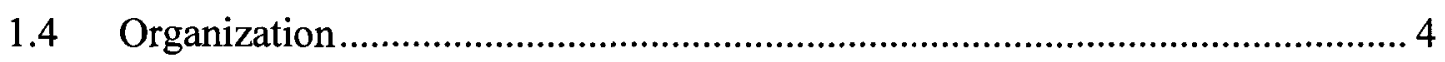

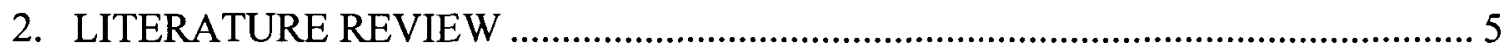

2.1 Review of product development success literature ............................................ 5

2.2 Review of open source software literature ....................................................... 8

2.2.1 Open source software project............................................................ 8

2.2.2 Interest in open source software project development.......................... 12

2.2.3 Open source software project success................................................... 13

2.3 Software types ............................................................................................... 16

2.4 Lessons learned from the literature ............................................................... 18

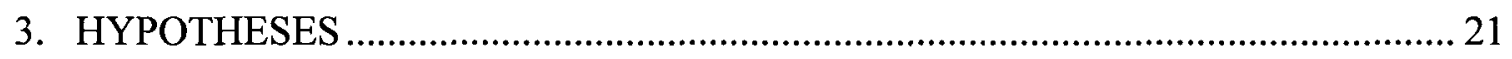

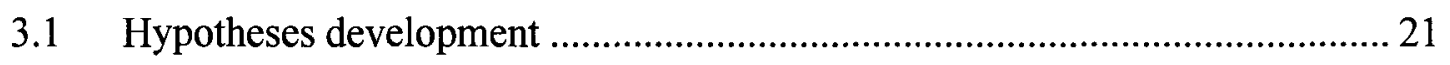

3.1.1 Number of OSS developers.............................................................. 22

3.1.2 Experience of OSS developers......................................................... 23

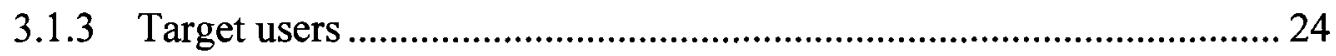

3.1.4 Programming language type used to develop OSS ............................... 25

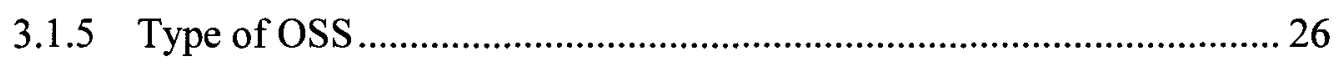

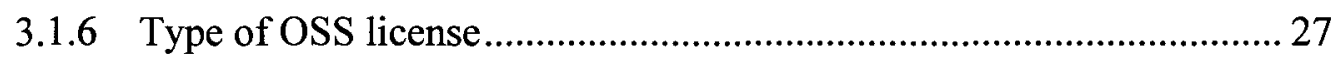

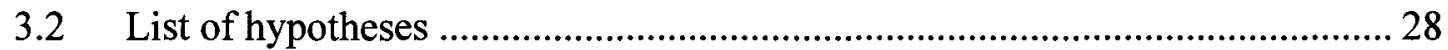

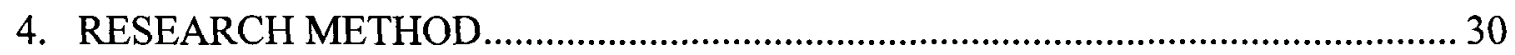




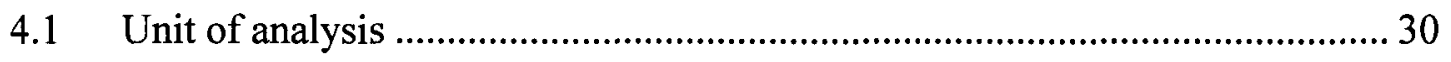

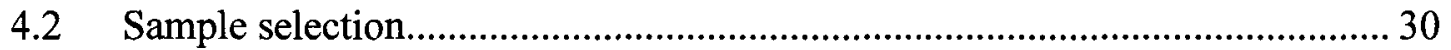

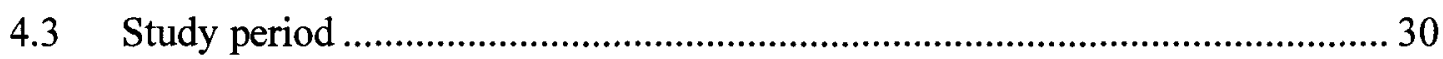

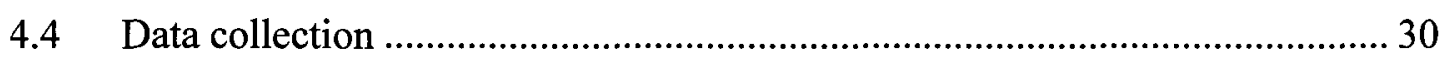

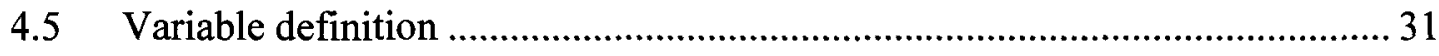

4.5.1 Number of developers ..................................................................... 31

4.5.2 Experience of developers ................................................................. 31

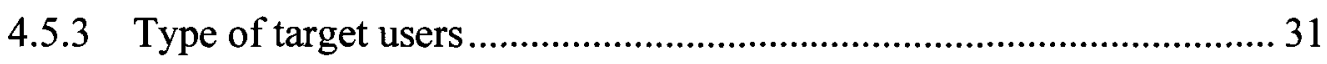

4.5.4 Type of programming language ......................................................... 32

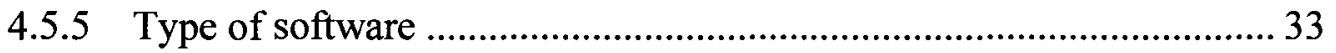

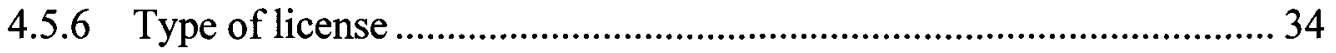

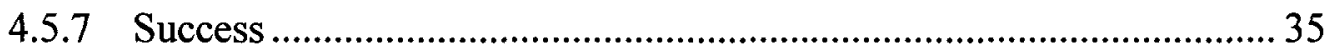

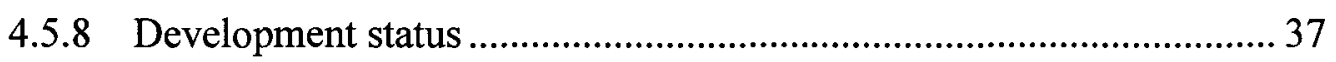

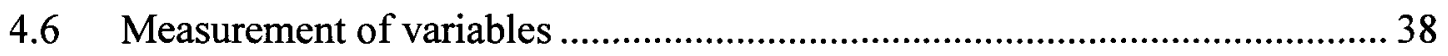

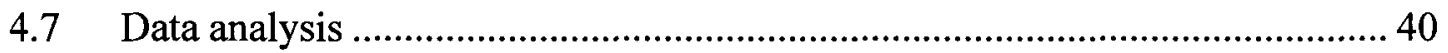

Hypothesis 1 . Number of developers is positively associated with the success of OSS projects .................................................................................... 41

Hypothesis 2. Experience of developers is positively associated with the success of OSS projects ................................................................... 42

Hypothesis 3. Targeting developers as users is positively associated with the success of OSS projects ..................................................................... 42

Hypothesis 4. Using a commonly used programming language is positively associated with the success of OSS projects ......................................... 42

Hypothesis 5. Development of application development and deployment tools is positively associated with the success of OSS projects..................... 43

Hypothesis 6. Use of non-restrictive OSS licenses is positively associated with the success of OSS projects................................................................... 43

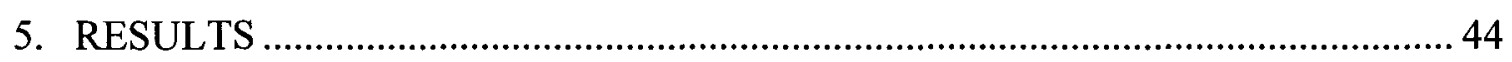

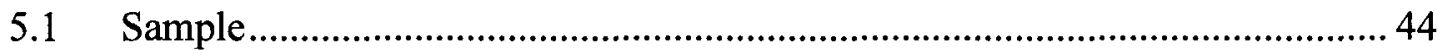

5.2 Descriptive statistics................................................................................ 50

5.3 Multivariate General Linear Model (GLM) .................................................. 55 
5.4 Hypothesis 1. Number of developers is positively associated with the success of OSS projects

5.5 Hypothesis 2. Experience of developers is positively associated with the success of OSS projects

5.6 Hypothesis 3. Targeting developers as users is positively associated with the success of OSS projects

5.7 Hypothesis 4. Using a commonly used programming language is positively associated with the success of OSS project.

5.8 Hypothesis 5. Development of application development and deployment tools is positively associated with the success of OSS projects.

5.9 Hypothesis 6. Use of non-restrictive OSS license is positively associated with the success of OSS projects................................................................................. 94

5.10 Summary of the results organized by hypothesis........................................... 100

5.11 Production/stable and mature OSS projects................................................... 111

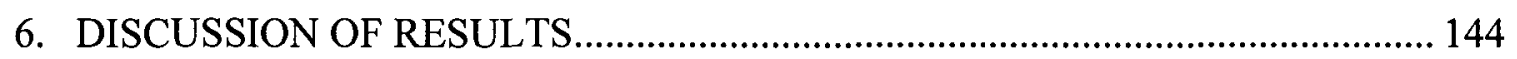

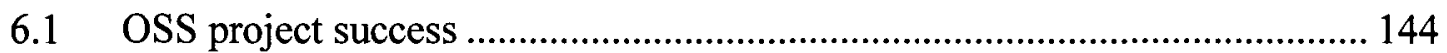

6.2 Factors that significantly affect OSS project success .................................... 145

6.3 OSS projects that develop application development and deployment tools . 146

6.4 OSS projects that attract a greater number of experienced developers........... 146

6.5 OSS projects that target developers as users.................................................. 148

6.6 Factors that do not significantly affect OSS project success .......................... 148

6.7 Development status affect factors-success relationship .................................. 150

6.8 Production/stable and mature OSS projects that develop application development and deployment tools............................................................... 151

7. CONCLUSIONS, LIMITATIONS, AND SUGGESTIONS FOR FUTURE

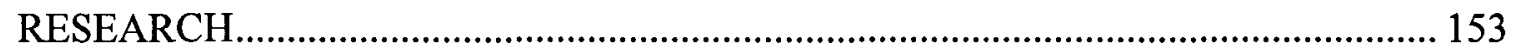

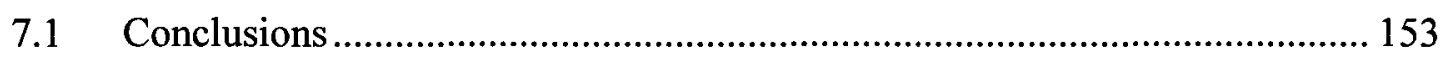

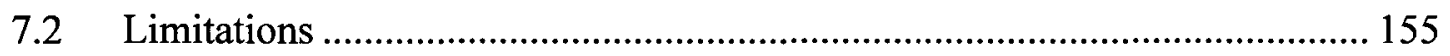

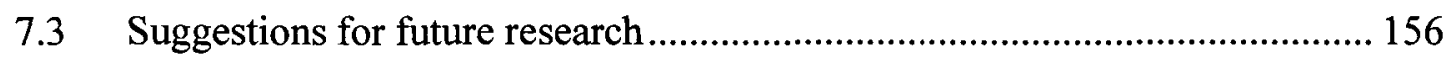

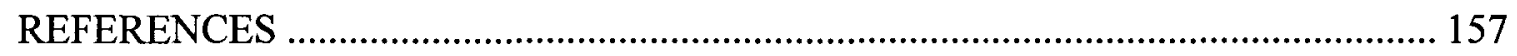

viii 


\section{LIST OF TABLES}

Table 1. Comparison of GPL, LGPL, and BSD open source licenses (Nissila, 2004). 11

Table 2. Software taxonomy by IDC (2003).................................................................. 17

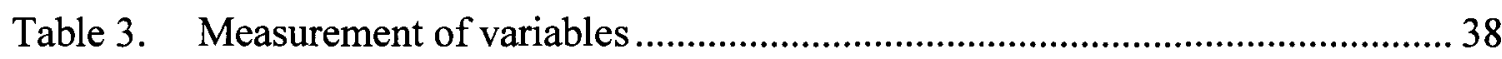

Table 4. Descriptive statistics of dependent variables ................................................. 50

Table 5. Descriptive statistics of dependent variables with transformations ..................53

Table 6. Levene's test for homogeneity of variances for number of downloads and number of releases across target users types, programming language types, software types, types of license, and development status.................................. 57

Table 7. Box's M test for homogeneity of covariance between number of downloads and number of releases across target users types, programming language types, software types, types of license, and development status

Table 8. Interaction effects between number of downloads, number of releases and target users type, programming language type, software type, license type, development status on number of downloads and number of releases .............59

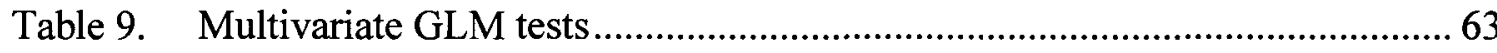

Table 10. Multiple comparisons of average number of downloads across types of target users

Table 11. Multiple comparisons of average number of releases across types of target users

Table 12. Multiple comparisons of average number of downloads across types of software 73

Table 13. Multiple comparisons of average number of releases across software types . 74

Table 14. Spearman correlation between number of developers and measures of success of OSS development project .75

Table 15. Spearman correlation between experience of developers and measures of success of OSS development project

Table 16. Levene test for homogeneity of variances for number of downloads and number of releases across types of target users 
Table 17. Welch and Brown-Forsythe robust $F$ tests of equality of means of number of downloads across types of target users

Table 18. Multiple comparisons of average number of downloads across types of target users

Table 19. One-Way ANOVA test of equality of means of number of releases across types of target users

Table 20. Multiple comparisons of average number of releases across types of target users

Table 21. Levene test for homogeneity of variances for number of downloads and number of releases across programming language types.

Table 22. One-Way ANOVA test of equality of means of number of downloads across programming language types

Table 23. Welch and Brown-Forsyth robust $F$ tests of equality of means of number of releases across programming language types

Table 24. Levene test for homogeneity of variances for number of downloads and number of releases across types of software.

Table 25. One-Way ANOVA test of equality of means of number of downloads across types of software

Table 26. Multiple comparisons of average number of downloads across types of software 90

Table 27. One-Way ANOVA test of equality of means of number of releases across types of software

Table 28. Multiple comparisons of average number of releases across software types .93

Table 29. Levene test for homogeneity of variances for number of downloads and number of releases across types of license

Table 30. Welch and Brown-Forsythe robust $F$ tests of equality of means of number of downloads across types of license

Table 31. Multiple comparisons of average number of downloads across license types 97

Table 32. One-Way ANOVA test of equality of means of number of releases across types of license 98

Table 33. Multiple comparisons of average number of releases across license types .... 99 
Table 34. Summary of test results organized by hypothesis

Table 35. Levene's test for homogeneity of variances for number of downloads and number of releases across target users types, programming language types, software types, and types of license

Table 36. Box's M test for homogeneity of covariance between number of downloads and number of releases across target users types, programming language types, software types, and types of license

Table 37. Multivariate GLM tests.

Table 38. Multiple comparisons of average number of downloads across types of software.

Table 39. Multiple comparisons of average number of releases across software types 118

Table 40. Spearman correlations between number of developers and measures of success of OSS project

Table 41. Spearman correlations between experience of developers and measures of success of OSS project

Table 42. Levene test for homogeneity of variances for number of downloads and number of releases across types of target users

Table 43. Welch and Brown-Forsythe robust $F$ tests of equality of means of number of downloads across types of target users

Table 44. One-Way ANOVA test of equality of means of number of releases across types of target users

Table 45. Levene test for homogeneity of variances for number of downloads and number of releases across programming language types

Table 46. One-Way ANOVA test of equality of means of number of downloads across programming language types

Table 47. Welch and Brown-Forsyth robust $F$ tests of equality of means of number of releases across programming language types

Table 48. Levene test for homogeneity of variances for number of downloads and number of releases across types of software.

Table 49. Welch and Brown-Forsythe robust $F$ tests of equality of means of number of downloads across types of software 
Table 50. One-Way ANOVA test of equality of means of number of releases across types of software

Table 51. Multiple comparisons of average number of releases across software types 131

Table 52. Levene test for homogeneity of variances for number of downloads and number of releases across types of license

Table 53. Welch and Brown-Forsythe robust $\mathrm{F}$ tests of equality of means of number of downloads across types of license

Table 54. One-Way ANOVA test of equality of means of number of releases across types of license.

Table 55. Summary of test results organized by hypothesis 136 


\section{LIST OF FIGURES}

Figure 1. OSS projects by type of target user...................................................... 45

Figure 2. OSS projects by type of programming language ..................................... 46

Figure 3. OSS projects by type of software developed ............................................. 47

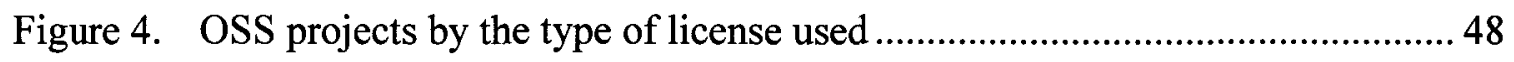

Figure 5. OSS projects by their development status ................................................ 49

Figure 6. Histogram: Number of downloads....................................................... 51

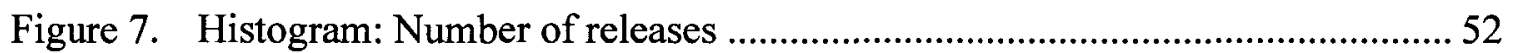

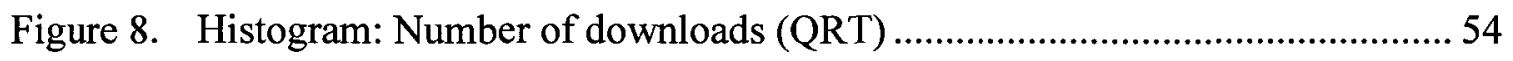

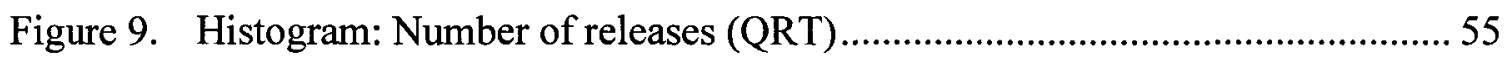




\section{LIST OF APPENDICES}

Appendix A. List of projects in the sample ................................................... 164 


\section{INTRODUCTION}

\subsection{Objective}

The objective of this exploratory research is to examine the factors that contribute to the success of open source software (OSS) projects. The explanatory factors examined in this research were identified from a review of the literature. These factors are: number of developers, experience of developers, target user type, programming language type, software type, license type, and development status.

Traditionally, software product success is measured from the perspective of corporate users who purchase the software, whereas the success of OSS projects seems to depend on the continued contribution of volunteer developers (Crowston, Annabi, Howison, and Masango, 2004). According to the product development literature, product success and process performance influence the financial success of a product (Brown and Eisenhardt, 1995). Success measures such as profits, market share, development cost, development time, and engineering productivity are difficult to apply to open source software.

For the purpose of identifying what measures of project success to use in this research, 700 developers were asked via email to define success of their OSS projects; 70 replied. Most of those who replied suggested number of downloads and number of releases. These two measures of success, not conventionally used to measure product development project success, were used in this research. 


\subsection{Relevance}

This research is relevant because its results increase our understanding of which OSS projects are likely to succeed. Knowing what factors contribute to OSS success will assist company managers and entrepreneurs who wish to set up successful OSS projects as well as project managers who wish to incorporate OSS into their development projects.

Better understanding of the factors that contribute to the success of OSS projects will help company managers and entrepreneurs to avoid costly mistakes and reduce the risk of failure when setting up OSS projects. Moreover, this understanding will also help project managers reduce the cost of having to change an OSS component due to the failure of the OSS project that produces it.

\subsection{Contribution}

Most of the studies on open source are case based and address issues of developing, testing, and releasing OSS code (Gallivan, 2001). However, empirical studies of the factors that contribute to OSS project success are lacking (Comino, Manenti, and Parisi, 2005; Koch, 2004).

This research makes at least five contributions. First, this research highlights the fact that developers who contribute to OSS projects define project success in ways 
not traditionally used to measure the success of the software development projects that companies undertake.

Second, the results of the research suggest that the open source projects which are designed to: i. produce application development and deployment tools, ii. attract a greater number of experienced developers, and iii. target developers as users, are more successful than other open source projects.

Third, the results of the research suggest that the type of programming language used and the type of software license do not affect the success of open source projects.

Fourth, the results of the research suggest that production/stable or mature OSS projects that produce application development and deployment tools are more successful than OSS projects that produce application software and system infrastructure software.

Finally, the results of the research suggest that the development status of an OSS project affects the relationship between factors such as number of developers, experience of developers, target users type, programming language type, type of open source software developed, and type of open source license and the success of the OSS project. 


\subsection{Organization}

The thesis is organized into seven chapters. Chapter 1 is the introduction. Chapter 2 reviews the academic literature and provides the lessons learned from it. Chapter 3 develops the hypotheses that were tested. Chapter 4 describes the research strategy and method to be used. Chapter 5 provides the results obtained when testing the hypotheses. Chapter 6 discusses the results obtained. Finally, Chapter 7 provides the conclusions, limitations, and suggestions for future research. 


\section{LITERATURE REVIEW}

This chapter is organized into four sections. The first section reviews the literature on product development success. The second section reviews the literature on open source software. The third section describes the software taxonomy provided by the International Data Corporation (IDC). Finally, section four provides the lessons learned from reviewing the literature.

\subsection{Review of product development success literature}

Clearly understanding the factors that contribute to product success can help top management teams and development project managers allocate required R\&D resources and increase the demand for new products (Zirger and Maidique, 1990).

Rational planning and execution, autonomous problem solving by team members, high communication and organization of work according to the requirements of the development task results in successful product development (Brown and Eisenhardt, 1995).

Competent people should staff product development projects (Brown and Eisenhardt, 1995). Skills of employees are very crucial for the success of new product development (Storey and Easingwood, 1996; Brown and Eisenhardt 1995). 
For product development success, it is important to properly define an attractive market as target market for the product (Brown and Eisenhardt, 1995; Cooper and Kleinschmidt, 1987). Identification of users as well as their needs contribute to the success of product development (Brown and Eisenhardt, 1995). If the company understands the market place and the customer understands the product offering then chances of product success increase (Storey and Easingwood, 1996).

Developing a new product that provides new benefits, satisfies customers' needs, and solves customers' problems increases the likelihood of its success (Cooper and Kleinschmidt, 1987; Storey and Easingwood, 1996). The provision of unique benefits to customers is critical for the success of new product development (Brown and Eisenhardt, 1995).

Focusing on financial returns is the traditional way of measuring new product development success. However, it is not the only important measure of success. A new product can be successful if it has a major impact on the market or if it provides a new opportunity to the company (Cooper and Kleinschmidt, 1987). According to Page (1993), customer need satisfaction is the most common non-financial measure of the success of a new product.

A number of dimensions are used to assess product success. It is unlikely that a single dimension is used to assess product success. For example, profit and sales performance assess financial success of the product; opportunity window assesses the degree to which 
the new product opened up new opportunities to the company; and market impact specifies the impact of the product on market share (Cooper and Kleinschmidt, 1987).

According to Griffin and Page (1993), the three independent dimensions of project success are: customer-based success, financial success, and technical or process-based success. A firm can assess the success or failure of a development project in terms of customer satisfaction, financial return and technical advantage (Griffin and Page, 1996).

Griffin and Page (1996), argued that in every firm, new products are developed for different reasons. Depending on the project strategy, measures of product success can be different. In a very competitive market, new products may have to be developed to retain current customers. Product development may also be used as a tool to attract new customers or market when revenue growth is required. For most projects, customer based success is mostly assessed by customer satisfaction with the product and customer acceptance, financial success is indicated by the degree to which the project met profit goals, and performance-based success is measured by the degree to which the project provides a competitive advantage (Griffin and Page, 1996).

Success of product development can be interpreted in terms of efficiency and effectiveness. Efficient product development means less development cost, less time to market, and greater speed, productivity and performance of the product development process. Effectiveness of the product means fit of the product with firm competencies and market needs, revenue, profitability, and market share (Brown and Eisenhardt, 1995). 


\subsection{Review of open source software literature}

\subsubsection{Open source software project}

OSS is software whose source code is distributed free of charge to all users under an open source license. These users can further modify and distribute the software free of charge. Open source license allows anyone to access source code, modify the software, and redistribute the software with or without modification (Open Source Initiative, 2005). An OSS project is the network of a community of developers who are geographically distributed. Developers contribute to the OSS project's activities through the Internet (Krogh and von Hippel, 2003; Freshtman and Gandal, 2004; Evers, 2000).

Projects protect their work by using trademarks and license of the software (O'Mahony, 2003). Lerner and Tirole (2005) argued that timing, exclusivity, and fee structure are important aspects for licensing of intellectual property. However, in case of open source software projects these are irrelevant. Hence, various open source leaders jointly establish criteria for open source licensing (Open Source Initiative, 2005).

A software is said to be open source if it is released under a license approved by the Open Source Initiative (OSI). OSI standards for open source software licenses include the following provisions (Open Source Initiative, 2005).

- Availability of source code of the software at nominal or no charge

- Permission of redistribution of the source code without fee. 
- Permission of distribution of modified software without discrimination.

- Permission of distribution of modified software on the same terms as the original one.

For OSS projects any license can be chosen from a number of approved open source licenses. Further the OSS projects can create their own licenses as long as it fulfils the provisions mentioned above (Open Source Initiative, 2005).

Fershtman and Gandal (2004) and Lerner and Tirole (2005) have categorized open source licenses into three categories: very restrictive, moderately restrictive, and not restrictive.

- GNU General Public License (GPL) is the most popular open source license. According to the requirements of this license the source code be made available and that other software that incorporate code from a GPL licensed software must also make the source code fully available under GPL. It prohibits the mixing of open source and closed source software in any distributed work. Hence, software that use code from a GPL licensed software cannot become propriety software. The GPL is classified as "very restrictive license" (Freshtman and Gandal, 2004; Lerner and Tirole, 2005).

- GNU Lesser GPL (LGPL) is another popular license. It is less restrictive than GPL. It is flexible regarding to the mixing of open source and closed source software. It allows software to link with or employ code from other software that is not available under open source license. In other respects it is similar to GPL. 
The LGPL is classified as "moderately restrictive" license. Other moderately restrictive licenses are: Apple Public Source License 1.2, Common Public Source License, Eiffel Forum License, IBM Public License 1.0, Jabber OSL, Motosoto License, Mozilla Public License 1.0 \& 1.1, Nethack Public License, Nokia OSL, Qt Public License, Recoh Source Code License, Sleepycat License, and Sun Public license (Freshtman and Gandal, 2004; Lerner and Tirole, 2005).

- Berkeley Software Distribution (BSD) license has fewer restrictions than GPL and LGPL type of licenses. Commercial software can be developed using software under a BSD license as long as credit for the underlying code is given to the University of California. BSD license is classified as "non-restrictive" license. Other non-restrictive licenses are: Apache Software License, Artistic license, Intel OSL, MTT License, Open Group Test Suite License, Python (CNRI) License, Python Software foundation License, Sun Industry Standards Source License, University of Illinois/NCSA OSL, Vovida Software License 1.0, W3C License, X.Net License, Zope Public License 2.0, zlib/libpng License, and Public Domain License (Freshtman and Gandal, 2004; Lerner and Tirole, 2005).

Table 1 shows a comparison between GPL, LGPL, and BSD licenses (Nissila 2004).

West and O'Mahony (2005) have classified OSS projects into two types. One they called community-founded OSS projects, started and operated by individuals and group of developers. Second they called spun-out OSS projects, started initially by a company and later released as open source software. 
Table 1. Comparison of GPL, LGPL, and BSD open source licenses (Nissila, 2004)

\begin{tabular}{|l|l|l|l|l|}
\hline License & $\begin{array}{l}\text { Can be mixed } \\
\text { with non-free } \\
\text { software }\end{array}$ & $\begin{array}{l}\text { Modifications } \\
\text { can be taken } \\
\text { private and } \\
\text { not returned } \\
\text { to author }\end{array}$ & $\begin{array}{l}\text { Can be } \\
\text { licensed by } \\
\text { anyone }\end{array}$ & $\begin{array}{l}\text { Contains } \\
\text { special } \\
\text { privileges for } \\
\text { the original } \\
\text { copyright } \\
\text { holder over } \\
\text { user's } \\
\text { modifications }\end{array}$ \\
\hline GPL & No & No & No & No \\
\hline LGPL & Yes & No & No & No \\
\hline BSD & Yes & Yes & No & No \\
\hline
\end{tabular}

According to Raymond (1999), traditional software development is different than that of OSS development. He termed the former process as resembling a cathedral model and the later one resembling a bazaar model. OSS development depends on volunteer developers who develop the software by coordinating without a formal organizational structure and the software is generally provided freely. Therefore, in-time delivery, be within budget, and meeting specifications that are important for commercial software development may not apply in case of OSS (Stewart, Ammeter, and Maruping, 2005). 


\subsubsection{Interest in open source software project development}

The interest in OSS development is increasing both from individuals and organizations. Research on open source has focused on the motivation of individuals and companies to participate in open source software development. According to Bates, Wolf, and Lakhani (2002), individuals are motivated to participate in open source software development due to: fun, skill, freedom, and need. Increasing knowledge is the biggest benefit and losing sleep is the biggest cost for participation in open source software development. Ghosh, Glott, Krieger, and Robes (2002) found that participation in open source community, skill improvement, learning and knowledge sharing are the most important factors that motivate individuals to take part in open source software development. Hertel, Nieder, and Hermann (2003), emphasized that increase in personal career chances and improvement in one's own software tools could motivate developers to participate in open source development process. Bonaccorsi and Rossi (2003) found that social factors: conforming to the values of free software movement, placing source code and skills at the disposal of software community, and believing software should not be proprietary motivate individuals to participate in open source software development.

Bonaccorsi and Rossi (2003) found that companies participate in open source software development due to economical and technological incentives. Economical incentives include: affordability of innovation by small enterprises, ease of finding good IT specialists, and gaining reputation among customers and competitors. Technological incentives include: reliability and quality of OSS, bug fixing and software improvement, use of source code to develop new programs and solutions, accessibility to products that 
are not available in proprietary software market. According to Rossi and Bonaccorsi (2005), organizations participate in open source software projects because of extrinsic incentives whereas individuals do so due intrinsic motivation. They refer extrinsic motivation as the situation when need is fulfilled indirectly, especially with monetary compensation. However, in case of intrinsic motivation, need is fulfilled from the pleasures of carrying out any activity.

\subsubsection{Open source software project success}

Most of the studies on open source are case based and focus on a small number of glamorous and successful projects. Linux and Apache are the examples. The reason may be that both of these OSS projects are very successful in terms of their market acceptance (Gallivan, 2001).To expand product growth, increase market share, and increase penetration, companies are adopting the open source development model (Paulson, Succi, and Eberlein, 2004). Majority of the case studies address issues of developing, testing, and releasing OSS code (Gallivan, 2001). However, empirical studies of the factors that contribute to success are lacking (Comino, Manenti, and Parisi, 2005; Koch, 2004).

While there is a good understanding of the factors that contribute to success of the traditional software development model, similar empirical studies of the factors that contribute to the success of the open source development model are lacking (Comino, Manenti, and Parisi, 2005; Koch, 2004). 
For determining the suitability of open source software for an organization, Duijnhouwer and Widdows (2003) has developed the Open Source Maturity Model (OSMM). With the help of customer OSMM evaluates and analyze open source software by looking into its maturity, assessing whether it is suitable to business requirement or not, and comparing it with alternative commercial software. On the basis of this analysis, the customer can decide whether or not to use open source software.

Duijnhouwer and Widdows (2003), has defined twelve indicators that are used to assess strengths and weaknesses of open source products. These are licensing, age, human hierarchies, selling points, developer community, modularity, collaboration with other products, standards, support, ease of deployment, user community, and market penetration. These indicators can provide the basis for determining factors that may contribute to the success of OSS projects.

Projects with a large number of developers participating in their development seem more successful (Crowston and Scozzi, 2002; Healy and Schussman, 2003). With more developers working on the project, problems are quickly fixed and the rate of software development is increased (Raymond, 1999).

Open source software projects run by professionals are more successful than those run by amateurs. Successful OSS projects should have professional developers whose professionalism can be assessed using the length of their practical experience and professional qualification (Healy and Schussman, 2003). 
The OSS community is mostly comprised of user-developers, who have high software knowledge. An OSS project that targets user-developers, addresses their needs and solves their problems seems to be more successful (Crowston and Scozzi, 2002). As the users of the open source software are developers, therefore, its usefulness for them may be an important factor for its success (Stewart, Ammeter, and Maruping, 2005).

The selection of an open source license depicts the way in which users are approached and may affect the success of an OSS project (Duijnhouwer and Widdows, 2003). The people who initiate open source project select the license for the OSS project (Fershtman and Gandal, 2004). Most OSS projects use very restrictive and restrictive licenses (Lerner and Tirole 2002; O'Mahony 2003). The choice of restrictive license limits the possibilities of commercial use of the open source software. Developers with an idealistic approach or in need of recognition are more prone to contribute to projects with restrictive license. The choice of a less restrictive license increases the possibilities of commercial use and the chances of contribution of developers motivated by financial benefits (Comino, Manenti, and Parisi, 2005).

Fershtman and Gandal (2004) found that output per contributor of open source programs is much higher when licenses are less restrictive. The success of open source software was measured by the output per contributor. Comino, Manenti, and Parisi (2005) found that less restrictive the licensing terms the larger the likelihood of reaching an advanced development stage. License restrictiveness will be having negative effect on the popularity of open source software (Stewart, Ammeter, and Maruping, 2005). 
For software, success can be gauged in various manners. From the developers' point of view, success might be an active project or one that successfully releases software. From the users' point of view, satisfaction with the software could be the measure of success. Commercially, success can be measured by the number of users (Crowston and Scozzi, 2002).

Conventional measures of project success are difficult to apply to OSS projects. Traditionally, software product success is measured from the perspective of corporate users who purchase the software, whereas the success of OSS projects seems to depend on the continued contribution of volunteer developer (Crowston, Annabi, Howison, and Masango, 2004)

\subsection{Software types}

International Data Corporation (IDC) is a global market intelligence advisory firm with expertise in the information technology industry. IDC's software taxonomy represents a collectively exhaustive and mutually exclusive view of the worldwide software marketplace (Heiman and Byron, 2003). Table 2 shows the IDC software taxonomy. Peng (2004) used this for the categorization of Linux-based software products. 
Table 2. Software taxonomy by IDC (2003)

\begin{tabular}{|c|c|}
\hline Categories & Sub-categories \\
\hline Applications & $\begin{array}{l}\text { - } \text { Consumer software } \\
\text { - } \text { Collaborative application } \\
\text { - } \text { Content applications } \\
\text { - } \text { Back-office application } \\
\text { - } \quad \text { Engineering applications } \\
\text { - } \quad \text { CRM and Sales and Marketing applications }\end{array}$ \\
\hline $\begin{array}{l}\text { Application development and } \\
\text { deployment tools }\end{array}$ & $\begin{array}{l}\text { - Information and Data management software } \\
\text { - Application Design and construction software } \\
\text { - Application life-cycle management software } \\
\text { - Application deployment platforms } \\
\text { - } \text { Middleware } \\
\text { - Other development tools } \\
\text { - Information access and delivery }\end{array}$ \\
\hline System infrastructure software & 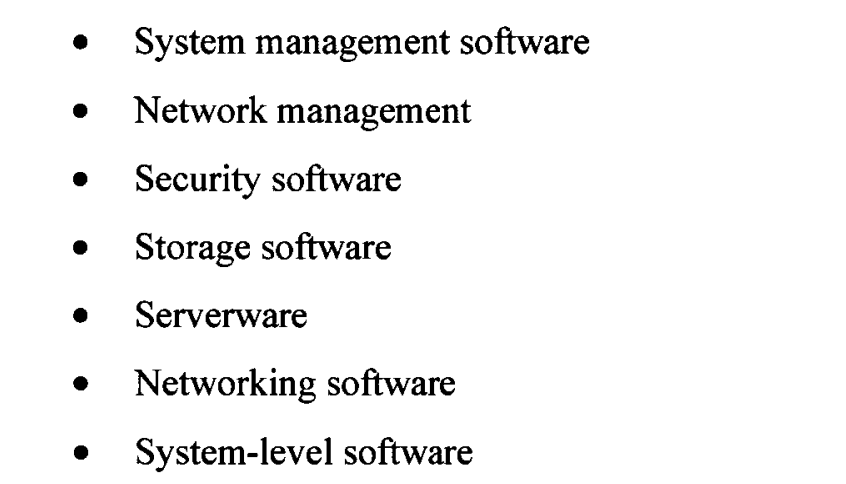 \\
\hline
\end{tabular}




\subsection{Lessons learned from the literature}

This section provides the key lessons learned from the literature review.

\section{Number of experienced designers and OSS project's success}

OSS projects with a greater number of experienced developers seem more successful (Crowston and Scozzi, 2002). With more developers the software development rate is increased (Raymond, 1999). Successful OSS projects should have professional developers whose professionalism can be assessed by length of practical experience and professional qualification (Healy and Schussman, 2003).

\section{Target market and OSS project's success}

For product development success it is important to define its target market (Cooper and Kleinschmidt, 1987). Identifying users is critical for the success of product development (Brown and Eisenhardt, 1995). If the company understands the market place then chances of product success are higher (Storey and Easingwood, 1996). Successful products are more likely if they are designed and targeted at attractive markets (Brown and Eisenhardt, 1995).

The OSS community is mostly comprised of user-developers, who have high software knowledge. These user-developers could be the attractive market for OSS projects. OSS 
projects that target these user-developers will be more successful (Crowston and Scozzi, 2002).

\section{Type of software and project's success}

Introducing a product that reduces customers' costs and solves their problem increases the likelihood that the product will be successful (Cooper and Kleinschmidt, 1987). Provision of unique benefits to customers is critical for the success of new product development (Brown and Eisenhardt, 1995). The likelihood of product success increases if the product performs a unique task or solves an important problem the customer has (Cooper and Kleinschmidt, 1987).

The three main categories of the software are applications, application development and deployment tools, and system infrastructure software (Heiman and Byron, 2003). The OSS community is mostly composed of user-developers, who have high software knowledge. OSS projects that address needs and solve problems of this community will be more successful (Crowston and Scozzi, 2002). The community should be more interested in the software that will help them in software development i.e., application development and deployment tools.

\section{Measures of project success}

For most development projects customer satisfaction and customer acceptance are two of the best measures of customer-based success. The degree to which profit goals are met 
may be an appropriate indicator of financial success. The degree to which a project provides a competitive advantage is the most useful indicator of performance-based success (Griffin and Page, 1996).

The success of a project is rarely measured using a single success measure. A number of measures are used (Cooper and Kleinschmidt, 1987). From the perspective of software developers, the success of a project may be measured in terms of the activity of the project or the number of times the software is released in a given period. From the perspective of a user, project success may be measured in terms of the frequency of use or satisfaction with the software (Crowston and Scozzi, 2002).

Traditionally, software product success is measured from the perspective of corporate users who purchase the software, whereas the success of OSS projects seems to depend on the continued contribution of volunteer developers (Crowston, Annabi, Howison, and Masango, 2004).

\section{Lack of empirical research on OSS success}

Most of the studies on open source are case based and focus on a small number of glamorous and successful projects. Empirical studies of the factors that contribute to success are lacking (Comino, Manenti, and Parisi, 2005; Koch, 2004). 


\section{HYPOTHESES}

This chapter is comprised of two sections. In section 3.1 the hypotheses to be tested are developed. Section 3.2 provides a list of the hypotheses developed.

\subsection{Hypotheses development}

In this section, six hypotheses are developed. For the purpose of this research, the success of an OSS project is measured using two indicators, number of downloads and number of releases of new software versions. The use of these two indicators as measures of success is the result of an on-line survey conducted by the researcher. The purpose of the survey was to figure out the success measures for OSS projects. Two hundred projects were randomly selected from www.sourceforge.net and three developers per project were sent emails asking, "How you would measure the success of an OSS project". The same question was also asked to 100 of the 156 developers listed on www.fsf.org as having contributed to the GNU project.

Of the 700 developers to which emails were sent, 70 replied. The majority of the 70 replies indicated that the success of an open source project can be measured using: number of downloads and number of releases. 


\subsubsection{Number of OSS developers}

Developers contribute to open source projects by concurrently writing, testing and debugging software (Zhao and Elbaum, 2003). The larger the number of developers examining the code may result in the finding of a greater number of bugs. This may accelerate the rate at which the software is completed (Raymond, 1999). Open source projects with a greater number of developers contributing to it; seem more successful (Crowston and Scozzi, 2002).

A mature OSS development project has a very large developer community contributing to it and the procedure for becoming a member of this community is documented (Duijnhouwer and Widdows, 2003). The saying 'many hands make light work' certainly holds true when dealing with an open source project. The greater the number of developers actively contributing to the OSS project, the smaller the likelihood that the OSS project will stall (Duijnhouwer and Widdows, 2003). Therefore,

Hypothesis 1. Number of developers is positively associated with the success of OSS projects.

The complementary hypotheses are:

Hypothesis 1a. Number of developers is positively associated with the number of downloads of OSS projects. 
Hypothesis 1b. Number of developers is positively associated with the number of releases of OSS projects

\subsubsection{Experience of OSS developers}

When competent people undertake product development activities, the likelihood of product success increases (Brown and Eisenhardt, 1995). The skills of employees are vital for new product success (Storey and Easingwood, 1996). Competent individuals are reassigned to new projects (Johne and Snelson, 1988).

Capable, motivated and experienced teams are crucial for project success in software development (Krishnan, 1998; Carmel and Sawyer, 1998; Curtis et al., 1988). Greater years of experience in the specific software domain help programmers to fix bugs earlier (Krishnan, 1998; Curtis, 1981).

The performance of programmers in software tasks depends upon their years of experience (Krishnan, 1998). Experienced software development teams are more familiar with the programming language used in OSS projects. This results in lower numbers of defects (Krishnan, 1998).

An OSS project needs developers who have the competencies required to develop the software. For OSS projects, the main competencies needed are the design and programming skills possessed by the developers who contribute to the project. Each developer should master particular programming languages, operating systems or 
programming environments and have developed experience in software applications (Crowston and Scozzi, 2002). Most contributors of OSS projects are experienced and professional programmers (Lakhani, Wolf, Bates, and DiBona, 2002). Experience of developers contributes to the success of OSS projects as well as conventional product development projects (Healy and Schussman, 2003). Therefore,

Hypothesis 2. Experience of developers is positively associated with the success of OSS projects.

The complementary hypotheses are:

Hypothesis 2a. Experience of developers is positively associated with the number of downloads of OSS projects.

Hypothesis $\mathbf{2 b}$. Experience of developers is positively associated with the number of releases of OSS projects.

\subsubsection{Target users}

Fit with market needs is a characteristic of successful products (Brown and Eisenhardt, 19995; Cooper and Kleinschmidt, 1987). Product success is more likely if developers understand the market place and product specifications (Story et al., 2000). Product success is also more likely if the customer understands the product offering (Storey and Easingwood, 1996). 
A large number of successful open source software addresses the needs of users who are also developers. It is difficult to find successful OSS projects that address the needs of unsophisticated users (Comino, Manenti, and Parisi, 2005). The communities of successful open source projects are comprised mostly of user-developers, who have high software knowledge. It is surmised that OSS projects that target users who are developers will be more successful (Crowston and Scozzi, 2002). Therefore,

Hypothesis 3. Targeting developers as users is positively associated with the success of OSS projects.

The complementary hypotheses are:

Hypothesis 3a. Targeting developers as users is positively associated with the number of downloads of OSS projects.

Hypothesis 3b. Targeting developers as users is positively associated with the number of releases of OSS projects.

\subsubsection{Programming language type used to develop OSS}

The programming language type used in an OSS project is an important feature of the project. The community that contributes to an OSS project may prefer the use of widely known programming languages - programming languages for which the competency of 
writing a program is widely available. Thus, OSS projects that use languages that are widely used may be more successful (Crowston and Scozzi, 2002). Therefore,

Hypothesis 4. Using a commonly used programming language is positively associated with the success of OSS projects.

The complementary hypotheses are:

Hypothesis 4a. Using a commonly used programming language is positively associated with the number of downloads of OSS projects.

Hypothesis $\mathbf{4 b}$. Using a commonly used programming language is positively associated with the number of releases of OSS project.

\subsubsection{Type of OSS}

Software can be organized into three main categories: applications, application development and deployment tools, and system infrastructure software (Heiman and Byron, 2003). The OSS community is mostly comprised of user-developers. OSS projects that address developers' needs and solve developers' problems may be more successful (Crowston and Scozzi, 2002). Code availability allows developers to modify the tools produced by OSS projects and make them fit their needs. Thus, OSS projects that develop application development and deployment tools may be more successful than OSS projects that develop applications and system infrastructure software. Therefore, 
Hypothesis 5. Development of application development and deployment tools is positively associated with the success of OSS projects.

The complementary hypotheses are:

Hypothesis 5a Development of application development and deployment tools is positively associated with the number of downloads of OSS projects.

Hypothesis 5b Development of application development and deployment tools is positively associated with the number of releases of OSS projects.

\subsubsection{Type of OSS license}

License restrictiveness will be having negative effect on the popularity of open source software (Stewart, Ammeter, and Maruping, 2005). The type of license under which the OSS is released may affect the success of the OSS project (Fershtman and Gandal, 2004; Duijnhouwer and Widdows, 2003).

Fershtman and Gandal (2004) found that the output per contributor of open source programs is much higher for software licenses that are less restrictive. Comino, Manenti, and Parisi (2005) found that the less restrictive the licensing terms are the larger the likelihood of the OSS project reaching an advanced development status. License restrictiveness will be having negative effect on the popularity of open source software (Stewart, Ammeter, and Maruping, 2005). Therefore, 
Hypothesis 6. Use of non-restrictive OSS licenses is positively associated with the success of OSS projects.

The complementary hypotheses are:

Hypothesis 6a Use of non-restrictive OSS license is positively associated with the number of downloads of OSS projects.

Hypothesis 6b Use of non-restrictive OSS license is positively associated with the number of releases of OSS projects.

\subsection{List of hypotheses}

This section lists the six hypotheses developed in section 3.1:

Hypothesis 1. Number of developers is positively associated with the success of OSS projects.

Hypothesis 2. Experience of developers is positively associated with the success of OSS projects.

Hypothesis 3. Targeting developers as users is positively associated with the success of OSS projects. 
Hypothesis 4. Using a commonly used programming language is positively associated with the success of OSS projects.

Hypothesis 5. Development of application development and deployment tools is positively associated with the success of OSS projects.

Hypothesis 6. Use of non-restrictive OSS license is positively associated with the success of OSS projects. 


\section{RESEARCH METHOD}

\subsection{Unit of analysis}

The unit of analysis is an OSS project.

\subsection{Sample selection}

The sample was drawn from a list of 100,341 OSS projects registered on the Sourceforge OSS project database (www.sourceforge.net) as of June 20, 2005. Convenience sampling technique was used. Sourceforge is the largest repository of OSS projects available on the Internet. It provides hosting services for project developers, allowing them to manage their source code, communicate with one another (via email, mailing lists and discussion forums), and make their work available for download. Although developers are located all over the world, Sourceforge's servers are where the day-to-day interaction and innovation actually happens for a very large numbers of OSS projects.

\subsection{Study period}

The data was collected between June 2005 and October 2005.

\subsection{Data collection}

The data was collected from the Sourceforge OSS project database (www.sourceforge.net). 


\subsection{Variable definition}

\subsubsection{Number of developers}

For each project, the number of developers was measured by counting the number of developers contributing to the development of the OSS as of the date shown in Appendix A. The project's summary page was used to obtain the information required to calculate number of developers.

\subsubsection{Experience of developers}

Experience of developers was measured as the sum of the years of experience of the developers contributing to the development of the OSS as of the date shown in Appendix A. The developers' info page was used to obtain the information required to calculate experience of developers.

\subsubsection{Type of target users}

Target users are the users for which the OSS is developed. Type of target users is a categorical variable. For this research, three types of target users were used: developers, system administrators, and end-users.

The variable Type of target users was measured on a nominal scale with values:

$1=$ developers 
$2=$ system administrators

$3=$ end-users

The OSS project's summary page indicates whether the project is intended for developers, system administrators or end-users. For example, the summary page of the "Slickworm" project states that the users the project targets are end-users. Therefore, the researcher assigned the Type of target users variable a value of 3.

\subsubsection{Type of programming language}

Programming language is the language developers that contribute to the OSS project used to write code. Type of programming language is a categorical variable. For this research, two types of programming language are defined: i. Commonly used programming languages and ii. Others.

Commonly used programming languages include $\mathrm{C}, \mathrm{C}++$, Java, and PHP. The competency for writing a program in these languages is widely available.

Others included programming languages other than $\mathrm{C}, \mathrm{C}++$, Java, and PHP.

The type of programming language was measured using a nominal scale with values:

$1=$ commonly used programming languages

$2=$ others 
The OSS projects' summary pages were used to obtain the information that identifies the programming language type used in the OSS project. For example, the summary page of the "Security Policy Manager" project states that the programming language used is $\mathrm{C}++$. $\mathrm{C}++$ is a commonly used programming language type. Therefore, the researcher assigned a value of 1 to the variable Type of programming language.

\subsubsection{Type of software}

Type of software is a categorical variable. For this research, software is categorized using the IDC software taxonomy (Heiman and Byron, 2003) into three major types: application software, application development and deployment tools, and system infrastructure software

Type of software was measured on a nominal scale with values:

$1=$ application software

$2=$ application development and deployment tools

$3=$ system infrastructure software

The OSS projects' home pages and summary pages were used to obtain information on the type of software developed. For example, the home page of the "Scintilla" project states that Scintilla is a free source code-editing component. As well as features found in standard text editing components, Scintilla includes features especially useful when editing and debugging source code such as support for syntax styling, error indicators, code completion and call tips. Therefore, the software produced by the Scintilla project 
was categorized as an application development and deployment tool. The researcher assigned a value of 2 to the variable Type of software.

\subsubsection{Type of license}

Type of license is a categorical variable. For this research, OSS licenses are categorized into the three categories defined by Fershtman and Gandal (2004) and Lerner and Tirole (2005): very restrictive, moderately restrictive, and non-restrictive licenses.

Very restrictive licenses include: GNU General Public License (GPL).

Moderately restrictive licenses include: GNU Lesser GPL (LGPL), Apple Public Source License 1.2, Common Public Source License, Eiffel Forum License, IBM Public License 1.0, Jabber OSL, Motosoto License, Mozilla Public License 1.0 \& 1.1, Nethack Public License, Nokia OSL, Qt Public License, Recoh Source Code License, Sleepycat License, and Sun Public license.

Non restrictive licenses include: Berkeley Software Distribution (BSD) license, Apache Software License, Artistic license, Intel OSL, MIT License, Open Group Test Suite License, Python (CNRI) License, Python Software foundation License, Sun Industry Standards Source License, University of Illinois/NCSA OSL, Vovida Software License 1.0, W3C License, X.Net License, Zope Public License 2.0, zlib/libpng License, and Public Domain License. 
The type of license variable was measured using a nominal scale with values:

$1=$ very restrictive licenses

$2=$ moderately restrictive licenses

$3=$ nonrestrictive licenses

The OSS projects' summary pages were used to obtain the information for the type of license variable. For example, the summary page of the "Scintilla" project states that the type of license under which the code was released is the Python (CNRI) License, a license categorized as a non-restrictive license. Therefore, the researcher assigned the value 3 to the Type of license variable.

\subsubsection{Success}

To identify the measures of success for OSS projects, the researcher conducted an online survey. Two hundred projects were randomly selected from www.sourceforge.net and three developers per project were sent emails asking them the following question: "How you would measure the success of an OSS project?" The same question was also asked to 100 of the 156 developers listed on www.fsf.org as having contributed to the GNU project. Out of the 700 people to whom emails were sent, 70 replied.

Twenty-eight respondents said that they would measure the success of an OSS project by counting the number of its users. Thirty two respondents said that the number of downloads is a reasonable proxy of success because it is an indicator of interest showed 
by users, user base, user satisfaction, number of users, and popularity of an OSS project. Nine respondents said that the release of a new version of an OSS project could be used as the measure of success. Maturity and stability, goal accomplishment, quality of code, page views, and need fulfillment were measure of success according to one or two developers.

The result of this on line survey suggested that a majority of the respondents supported the use of number of users, number of downloads, and number of releases as indicators of the success of OSS projects.

\section{Number of downloads}

Number of downloads was used as a proxy measure for the success of OSS projects. The OSS projects' statistics pages were used to obtain the number of downloads as of the dates shown in Appendix A.

\section{Number of releases}

Number of releases was used as a proxy measure of success of OSS projects. The OSS projects' summary pages were used to obtain the number of downloads as of the dates shown in Appendix A.

Each of the above success measures of OSS development projects has good face validity, in the sense that an OSS development project that many users download and has greater 
number of releases does seem like it deserves to be described as a success (Crowston, Annabi, and Howison, 2003).

\subsubsection{Development status}

Development status provides information about the maturity of OSS projects.

Sourceforge specifies six development statuses for OSS projects: 1. planning, 2. pre-

alpha, 3. alpha, 4. beta, 5. production/stable, and 6. mature. Each project registered on Sourceforge is classified into one of these six statuses. Its developers themselves report the development status of the OSS project. No formal definitions of these development statuses are available on Sourceforge (Comino, Manenti, and Parisi, 2005).

For this research the development status was measured using a nominal scale with values:

$1=1$ planning

$2=2$. pre-alpha

$3=3$. alpha

$4=4$. beta

$5=5$. production

$6=6$. mature

The OSS projects' summary pages were used to obtain the information for the development status variable. For example, the summary page of the "Scintilla" project 
states that the development status of this project is production. Therefore, the researcher assigned the value 5 to the Development status variable.

\subsection{Measurement of variables}

Table 3 provides a summary of how the variables used in this research were measured.

Table 3. Measurement of variables

\begin{tabular}{|l|l|}
\hline Variable & Measurement \\
\hline Number of developers & $\begin{array}{l}\text { Number of developers taking part in the development of the } \\
\text { OSS project }\end{array}$ \\
\hline $\begin{array}{l}\text { Experience of } \\
\text { developers }\end{array}$ & $\begin{array}{l}\text { Total years of experience of the developers taking part in the } \\
\text { development of the OSS project }\end{array}$ \\
\hline Type of target users & $\begin{array}{l}\text { Categorical variable measured on a nominal scale with values: } \\
1=\text { developers } \\
2=\text { system administrators } \\
3=\text { end-users }\end{array}$ \\
\hline
\end{tabular}




\begin{tabular}{|l|l|}
\hline $\begin{array}{l}\text { Type of programming } \\
\text { language }\end{array}$ & $\begin{array}{l}\text { Categorical variable measured on a nominal scale with values: } \\
1=\text { common programming languages (C, C++, Java, and PHP) } \\
2=\text { others }\end{array}$ \\
\hline Type of software & $\begin{array}{l}\text { Categorical variable measured on a nominal scale with values: } \\
1=\text { application software } \\
2=\text { application development and deployment tools } \\
3=\text { system infrastructure software }\end{array}$ \\
\hline Type of OSS license & $\begin{array}{l}\text { Categorical variable measured on a nominal scale with values: } \\
1=\text { very restrictive license } \\
2=\text { moderately restrictive license } \\
3=\text { nonrestrictive license }\end{array}$ \\
\hline Number of releases & $\begin{array}{l}\text { Total number of releases from the start of the OSS } \\
\text { development project to the date of data collection. }\end{array}$ \\
\hline Number of downloads & $\begin{array}{l}\text { Total number of downloads from the start of the OSS } \\
\text { development project to the date of data collection. }\end{array}$ \\
\hline
\end{tabular}




\begin{tabular}{|l|l|}
\hline Development status & $\begin{array}{l}\text { Categorical variable measured on a nominal scale with values: } \\
1=\text { planning } \\
2=\text { pre-alpha } \\
3=\text { alpha } \\
4=\text { beta } \\
5=\text { production } \\
6=\text { mature }\end{array}$ \\
\hline
\end{tabular}

\subsection{Data analysis}

To analyze the data, the SPSS software was used. First, bar graphs showing the OSS development projects by the type of target user, type of programming language used, type of software developed, type of licenses under which code is released and by their development status were produced.

Then the data was examined using a five-step procedure. In the first step, the histograms with normality curve of dependent variables: number of downloads and number of releases were drawn to examine how closely the data were Normally distributed. The descriptive statistics for these variables were also calculated. To decide whether or not a variable was Normally distributed, its Kurtosis and Skewness statistics were examined. A variable was deemed to be Normally distributed if its Skewness was within two times the standard error of the Skewness statistic and its Kurtosis was within -2 and +2 . 
In the second step, quad root transformations were used to transform the variables that were not Normally distributed. The intent was to provide distributions with the characteristics of a Normal distribution.

In the third step, the Multivariate General Linear Model (GLM) was used to explore the relationship between the factors expected to contribute to the success of an OSS project (number of developers, experience of developers, type of target users, type of programming language used, type of OSS developed and type of OSS license) and two proxies for success of OSS projects: number of downloads and number of releases.

In the fourth step, computing the Levene test checked the equality of variance for categorical variables.

Finally, in the fifth step, the six hypotheses were tested. The remainder of this section describes how each Hypothesis was tested.

\section{Hypothesis 1. Number of developers is positively associated with the success of OSS projects}

Spearman correlations were used to test hypotheses la and $1 \mathrm{~b}$. This test was used because the independent variable (number of developers) and the two dependent variables (number of downloads and number of releases) are quantitative variables. 
Hypothesis 2. Experience of developers is positively associated with the success of OSS projects

Spearman correlations were used to test Hypothesis $2 \mathrm{a}$ and $2 \mathrm{~b}$. This test was used because the independent variable (experience of developers) and the two dependent variables (number of downloads and number of releases) are quantitative variables.

Hypothesis 3. Targeting developers as users is positively associated with the success of OSS projects

The Welch and Brown-Forsythe robust $\mathrm{F}$ tests were used to test Hypothesis 3a and OneWay ANOVA test was used to test Hypothesis $3 \mathrm{~b}$. These tests were used because the independent variable (type of target users) is a categorical variable measured on a nominal scale and the two dependent variables (number of downloads, and number of releases) are quantitative variables.

\section{Hypothesis 4. Using a commonly used programming language is positively associated with the success of OSS projects}

The One-way ANOVA was used to test Hypothesis 4a and Welch and Brown-Forsythe robust $\mathrm{F}$ tests were used to test Hypothesis $4 \mathrm{~b}$. These test were used because the independent variable (type of programming language) is a categorical variable and the two dependent variables (number of downloads and number of releases) are quantitative variables. 
Hypothesis 5. Development of application development and deployment tools is positively associated with the success of OSS projects

The One-Way ANOVA test was used to test Hypothesis 5a and 5b.The test was used because the independent variable (type of software) is a categorical variable and the two dependent variables (number of downloads and number of releases) are quantitative variables.

Hypothesis 6. Use of non-restrictive OSS licenses is positively associated with the success of OSS projects

Welch and Brown-Forsythe robust F test were used to test Hypothesis 6a and One-way ANOVA test was used to test Hypothesis $6 \mathrm{~b}$. These tests were used because the independent variable (type of license) is a categorical variable and the two dependent variables (number of downloads and number of releases) are quantitative variables. 


\section{RESULTS}

This chapter has eleven sections. The first section describes the sample. The second section provides the descriptive statistics. The third section provides the results of testing the hypotheses using the Multivariate General Linear model. Sections four through nine examine the hypothesis one at a time. The tenth section summarizes the results obtained when testing the six hypotheses. Finally, the eleventh section provides the results obtained when testing the six hypotheses using a sub sample of OSS projects that have a production and stable development status.

\subsection{Sample}

The sample was comprised of 350 OSS projects. The sample was drawn from a list of 100,341 OSS projects registered with the Sourceforge OSS project database (www.sourceforge.net) as of June 20, 2005. Convenience sampling technique was used. The data was collected between June 2005 and October 2005. Appendix A shows the OSS projects included in the sample.

Figure 1 provides a bar graph of the OSS projects in the sample by type of target users. Of the 350 projects in the sample, $134(38 \%)$ targeted end users. 
Figure 1. OSS projects by type of target user

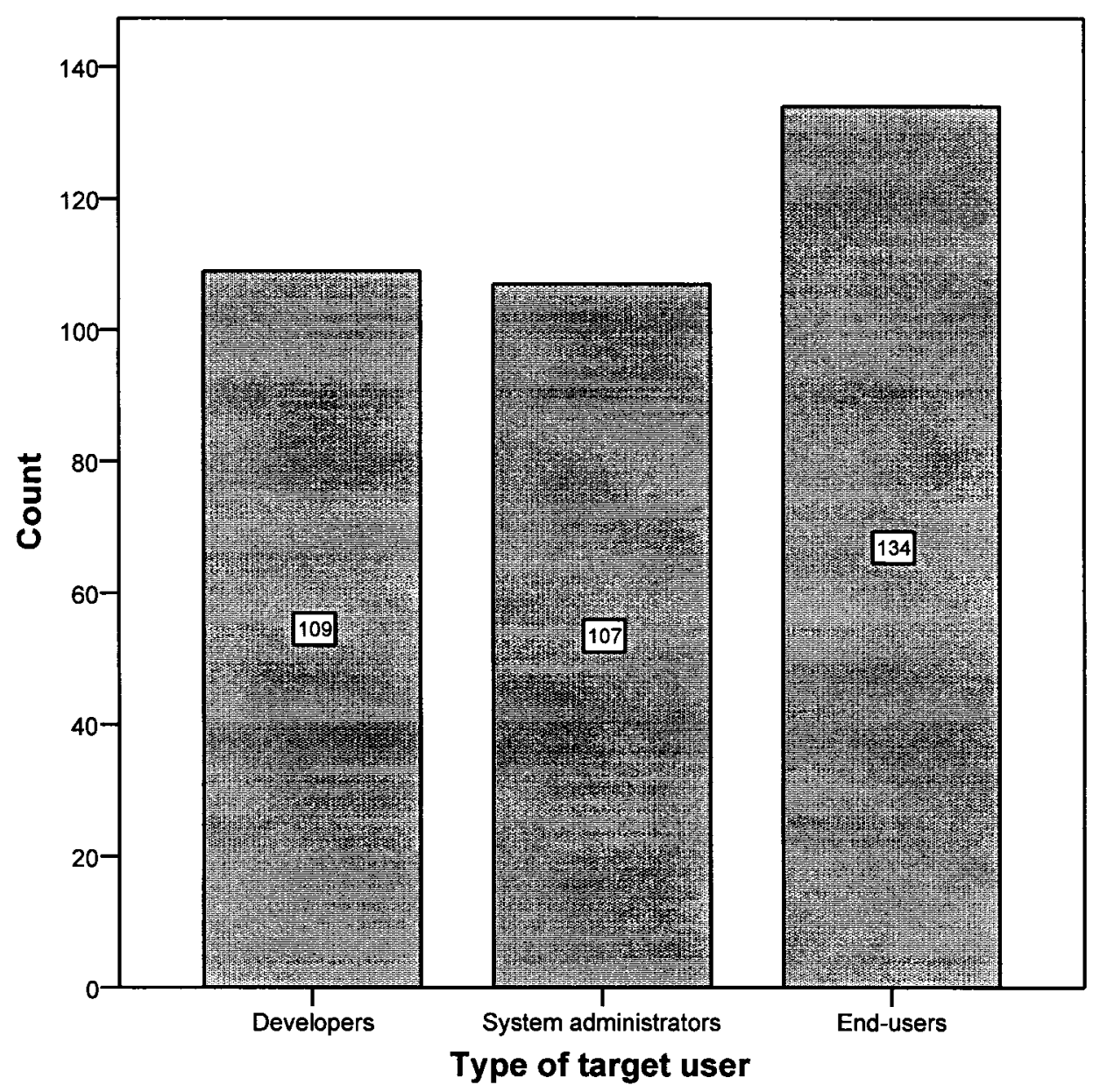

Figure 2 provides a bar graph of the OSS projects in the sample by type of programming language used. Of the 350 projects, $252(72 \%)$ used $\mathrm{C}, \mathrm{C}++$, Java, and PHP. The category called other included the following programming languages: ActionScript, Ada, APL, Applescript, ASP, AspectJ, ASP.NET, Assembly, AWK, BASIC, C\#, COBOL, 
Figure 2. OSS projects by type of programming language

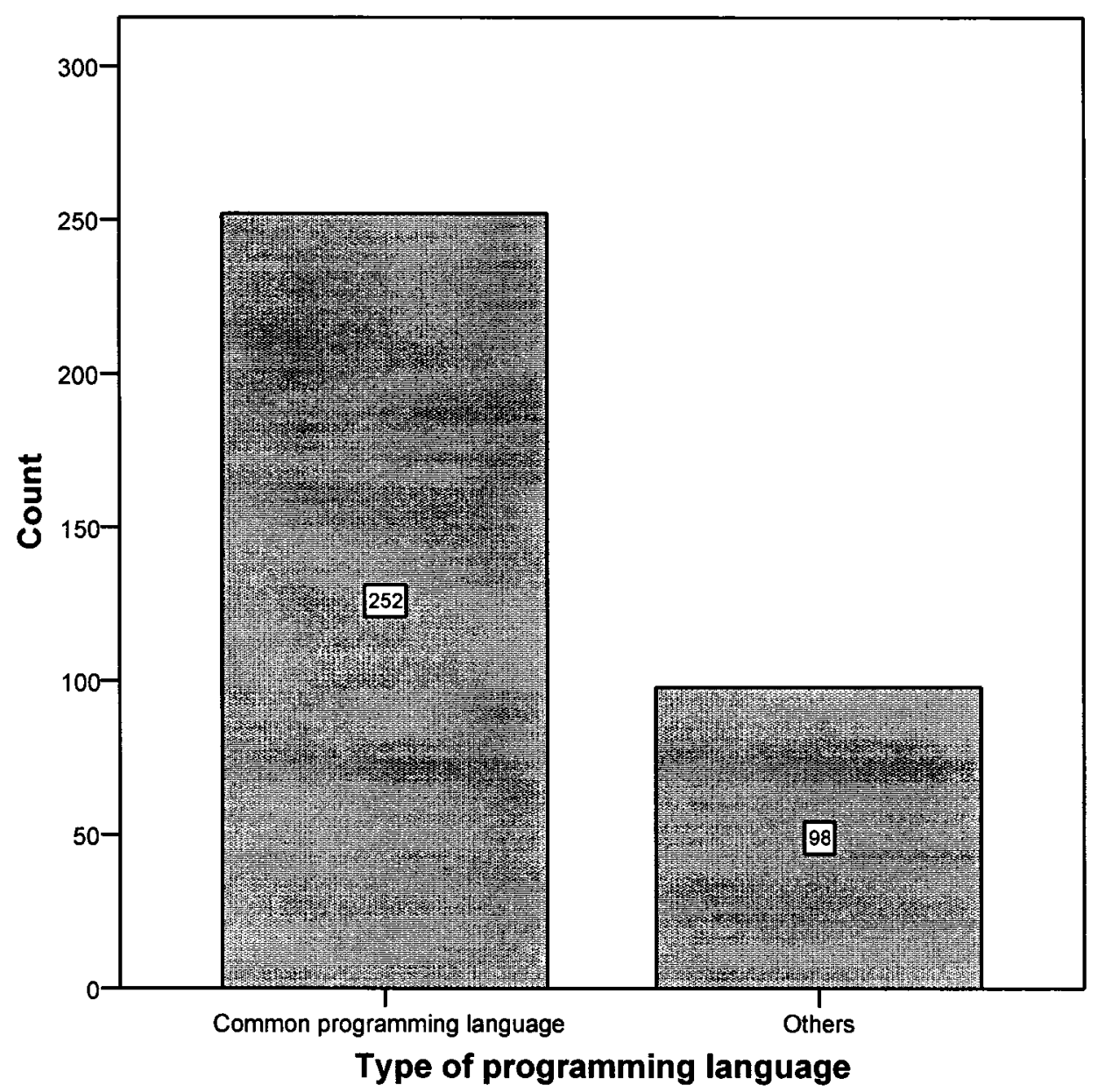

Cold Fusion, Common Lisp, D, Delphi/Kylix, Dylan, Eiffel, Emacs-Lisp, Erlang, Euler, Euphoria, Forth, Fortran, Groovy, Haskell, IDL, JSP, LabVIEW, Lisp, Logo, LPC, Lua, MATLAB, Modula, MUMPS, Oberon, Objective C, Object Pascal, OCaml, Pascal, Perl, Pike, PL/SQL, PROGRESS, Prolog, Python, REALbasic, REBOL, Rexx, Ruby, Scheme, Simula, Simulink, Smalltalk, S/R, Standard ML, Tcl, Unix Shell, VBScript, Visual Basic, Visual Basic.Net, Visual FoxPro, XBasic, Yacc, and Zope 
Figure 3 provides a bar graph of the OSS projects in the sample by type of software developed. Of the 350 projects in the sample, $129(40 \%)$ were application software.

Figure 3. OSS projects by type of software developed

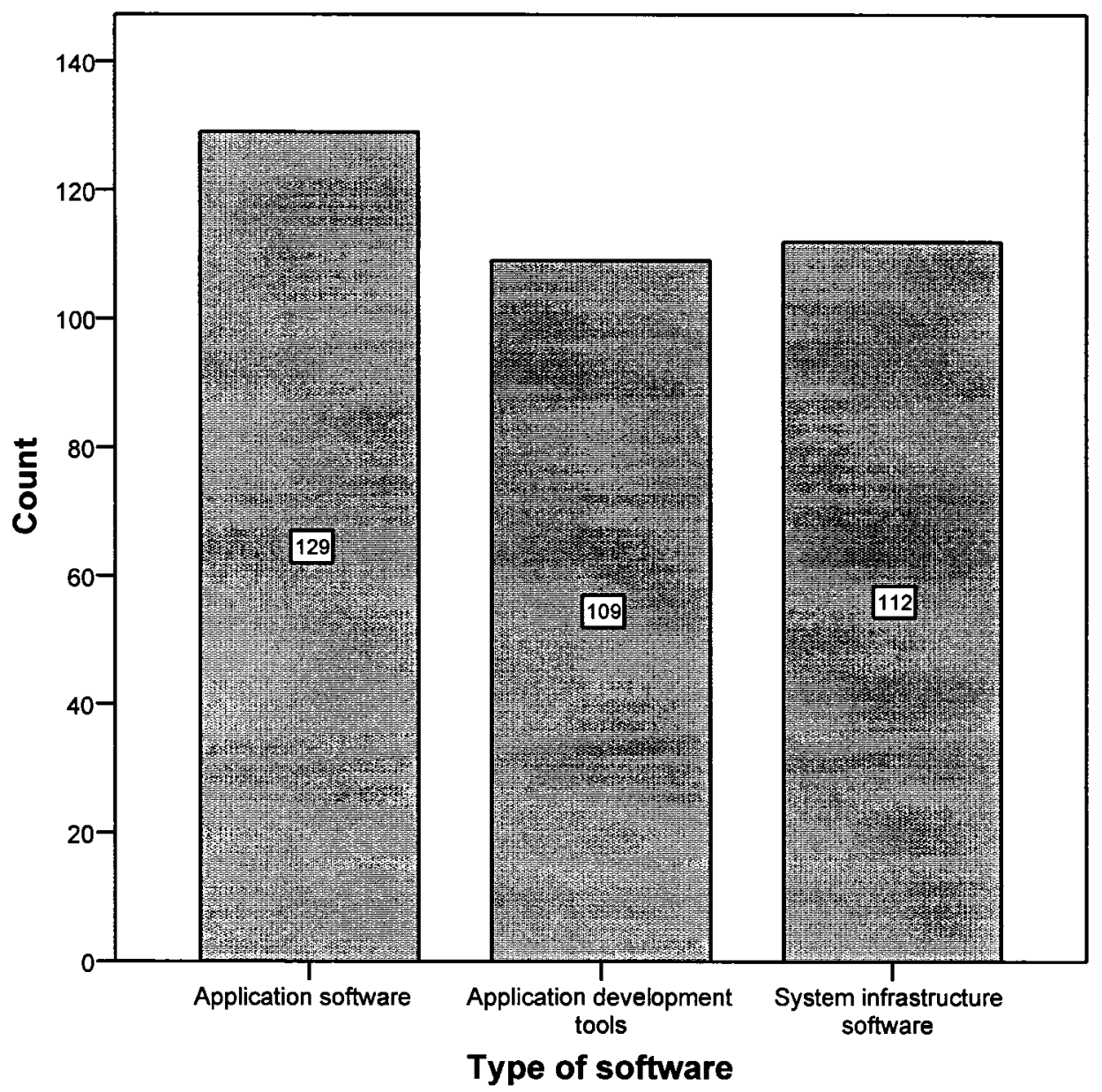

Figure 4 provides a bar graph of the OSS projects in the sample by type of license used. Of the 350 projects, 204 (58\%) used very restrictive OSS licenses. 
Figure 4. OSS projects by the type of license used

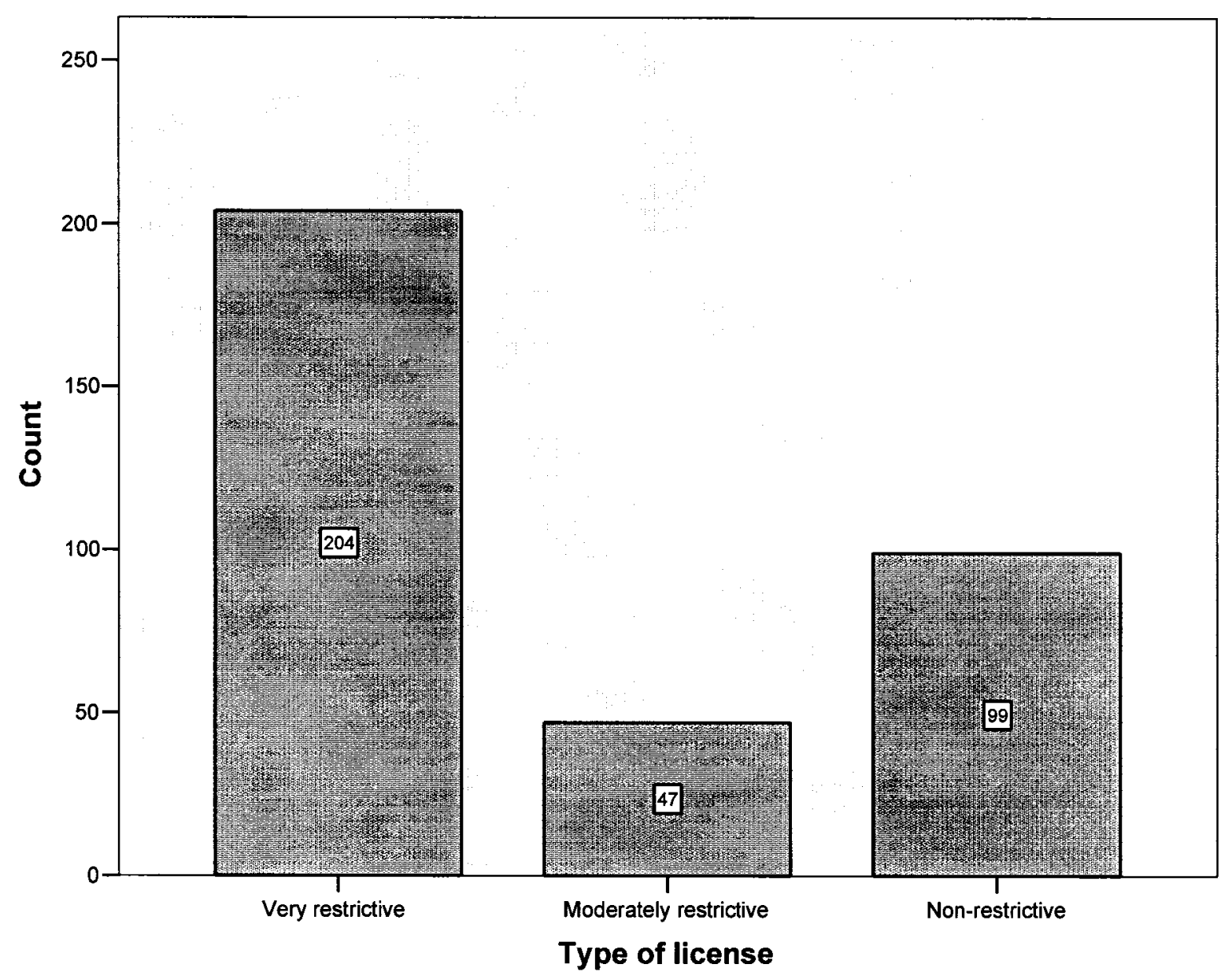

Figure 5 provides a bar graph of the OSS projects in the sample by their development status. Of the 350 projects in the sample, $76(22 \%)$ held a production/stable development status and $71(20 \%)$ held a beta development status. 
Figure 5. OSS projects by their development status

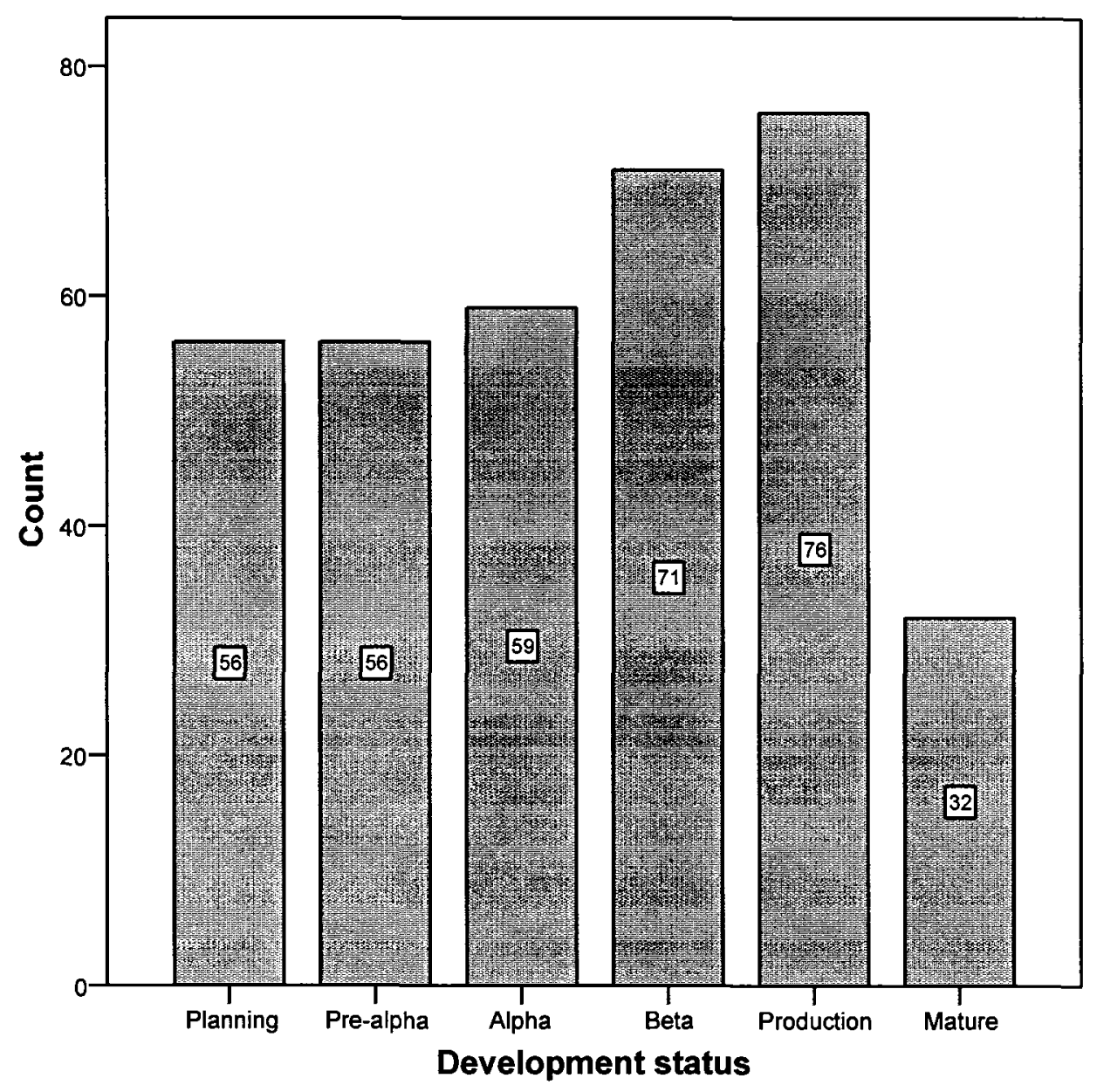




\subsection{Descriptive statistics}

Table 4 provides descriptive statistics of the two dependent variables used in this research: number of downloads and number of releases. To decide whether or not a variable was Normally distributed, its Kurtosis and Skewness statistics were examined. A variable was considered to be Normally distributed when its Skewness was within 2 times the standard error of the Skewness statistic and Kurtosis was within -2 and +2 .

Table 4. Descriptive statistics of dependent variables $($ Sample size $=350)$

\begin{tabular}{|r|c|c|c|c|c|c|c|}
\hline & Min & Max & Mean & $\begin{array}{c}\text { Std. } \\
\text { deviation }\end{array}$ & $\begin{array}{c}\text { Skewness } \\
\text { (Std. } \\
\text { error } \\
\mathbf{. 1 3 0}\end{array}$ & $\begin{array}{c}\text { Kurtosis } \\
\text { (Std. } \\
\text { error } \\
\mathbf{2 6 0}\end{array}$ & $\begin{array}{c}\text { Normally } \\
\text { distributed }\end{array}$ \\
\hline $\begin{array}{r}\text { Number of } \\
\text { downloads }\end{array}$ & 1 & 7744989 & 122764.89 & 594729.84 & 8.74 & 92.25 & No \\
\hline $\begin{array}{r}\text { Number of } \\
\text { releases }\end{array}$ & 1 & 307 & 14.51 & 25.60 & 5.84 & 52.38 & No \\
\hline
\end{tabular}

For each variable in Table 4, the Skewness is greater than twice the standard error and the Kurtosis is outside of the -2 to +2 range. Results in Table 4 indicate that Number of downloads and Number of releases are not Normally distributed.

Figures 6 and 7 provide histograms of the two dependent variables. The figures also suggest that the two variables are not Normally distributed. 
Figure 6. Histogram: Number of downloads

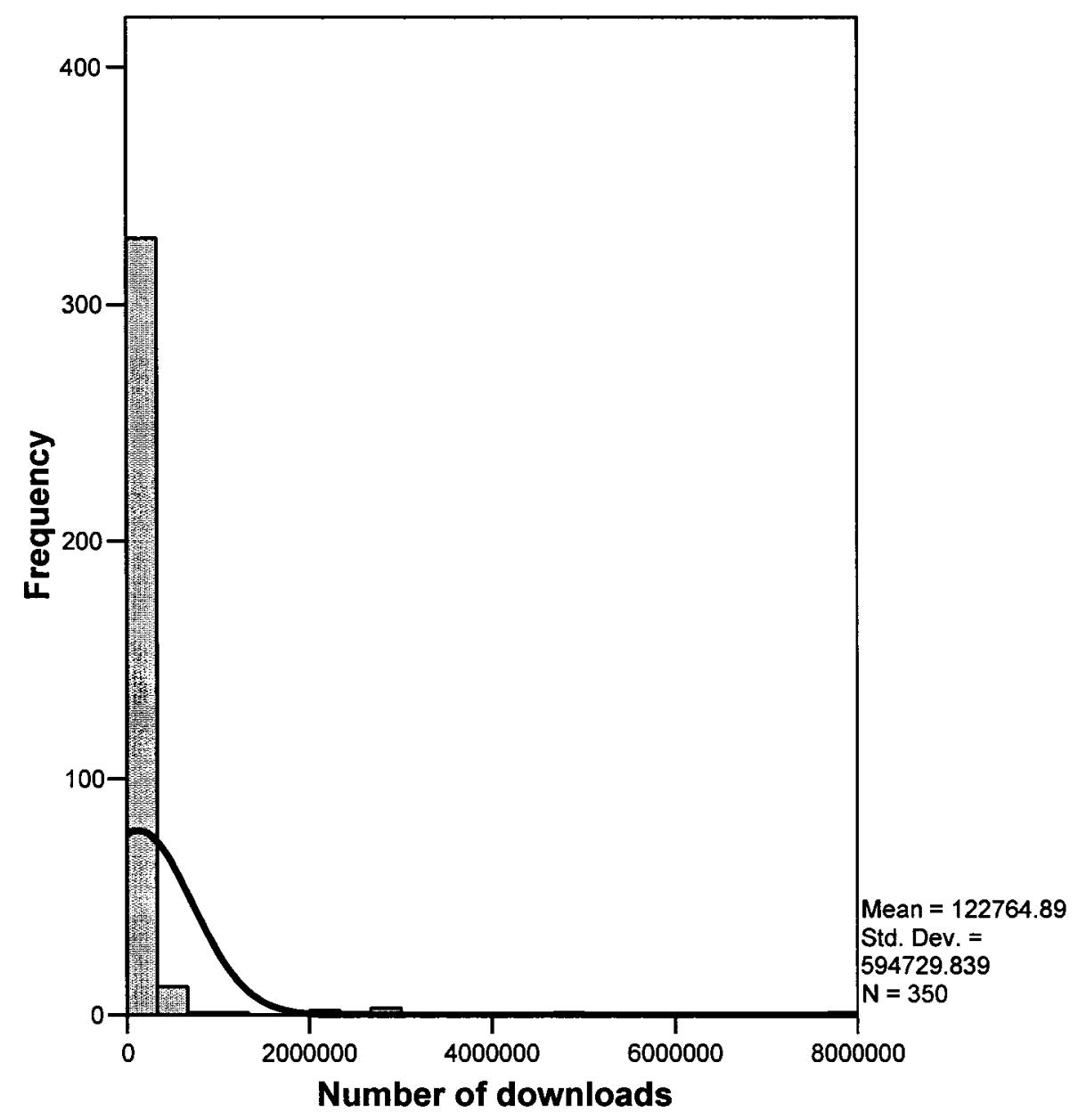


Figure 7. Histogram: Number of releases

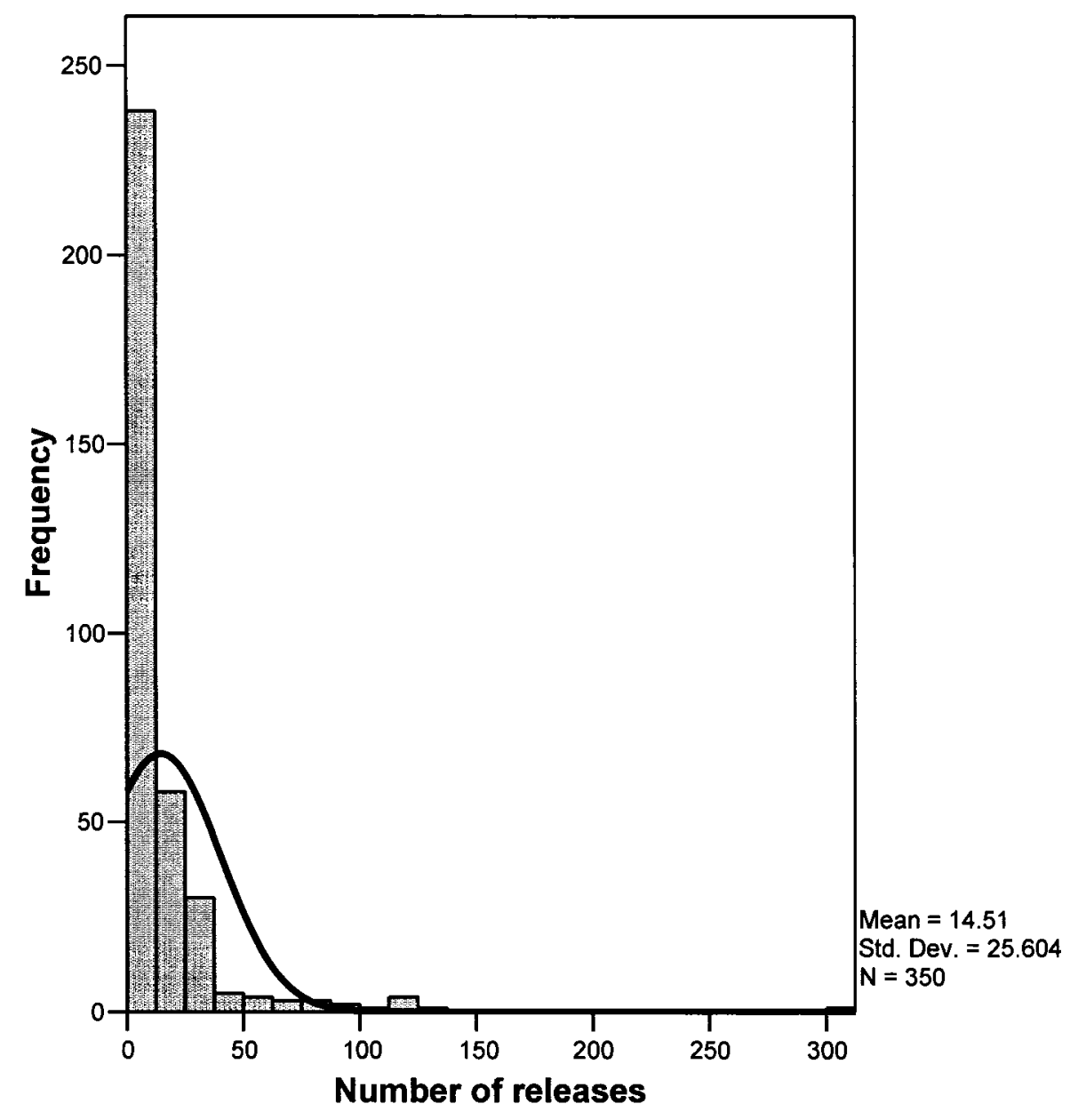

Quad root transformations were used in an attempt to generate Normally distributed variables. Table 5 provides descriptive statistics for the transformed variables (identified by adding a ' $Q R T$ ' in parentheses after the name of the variable). 
Table 5. Descriptive statistics of dependent variables with transformations $($ Sample size $=350)$

\begin{tabular}{|r|c|c|c|c|c|c|c|}
\hline & Min & Max & Mean & $\begin{array}{c}\text { Std. } \\
\text { deviation }\end{array}$ & $\begin{array}{c}\text { Skewness } \\
\text { (Std. } \\
\text { error } \\
\mathbf{. 1 3 0}\end{array}$ & $\begin{array}{c}\text { Kurtosis } \\
\text { (Std. } \\
\text { error } \\
\mathbf{2 6 0}\end{array}$ & $\begin{array}{c}\text { Normally } \\
\text { distributed }\end{array}$ \\
\hline $\begin{array}{r}\text { Number of } \\
\text { downloads (QRT) }\end{array}$ & 1.50 & 53.25 & 10.58 & 7.90 & 2.06 & 5.79 & No \\
\hline $\begin{array}{r}\text { Number of } \\
\text { releases (QRT) }\end{array}$ & 1.50 & 4.69 & 2.17 & .56 & .876 & 1.01 & Yes \\
\hline
\end{tabular}

The results in Table 5 suggest that the conditions for normality are improved after the quad transformation. The data for the square root of the number of downloads is close to being Normally distributed. For this variable, the Skewness is not much greater than twice the standard error. However, the Kurtosis is outside the -2 to +2 range. The data for the square root of number of releases is Normally distributed. The skewness is less than twice the standard error and the Kurtosis is within the -2 to +2 range.

Figures 8 and 9 provide the histograms of the transformed dependent variables. 
Figure 8. Histogram: Number of downloads (QRT)

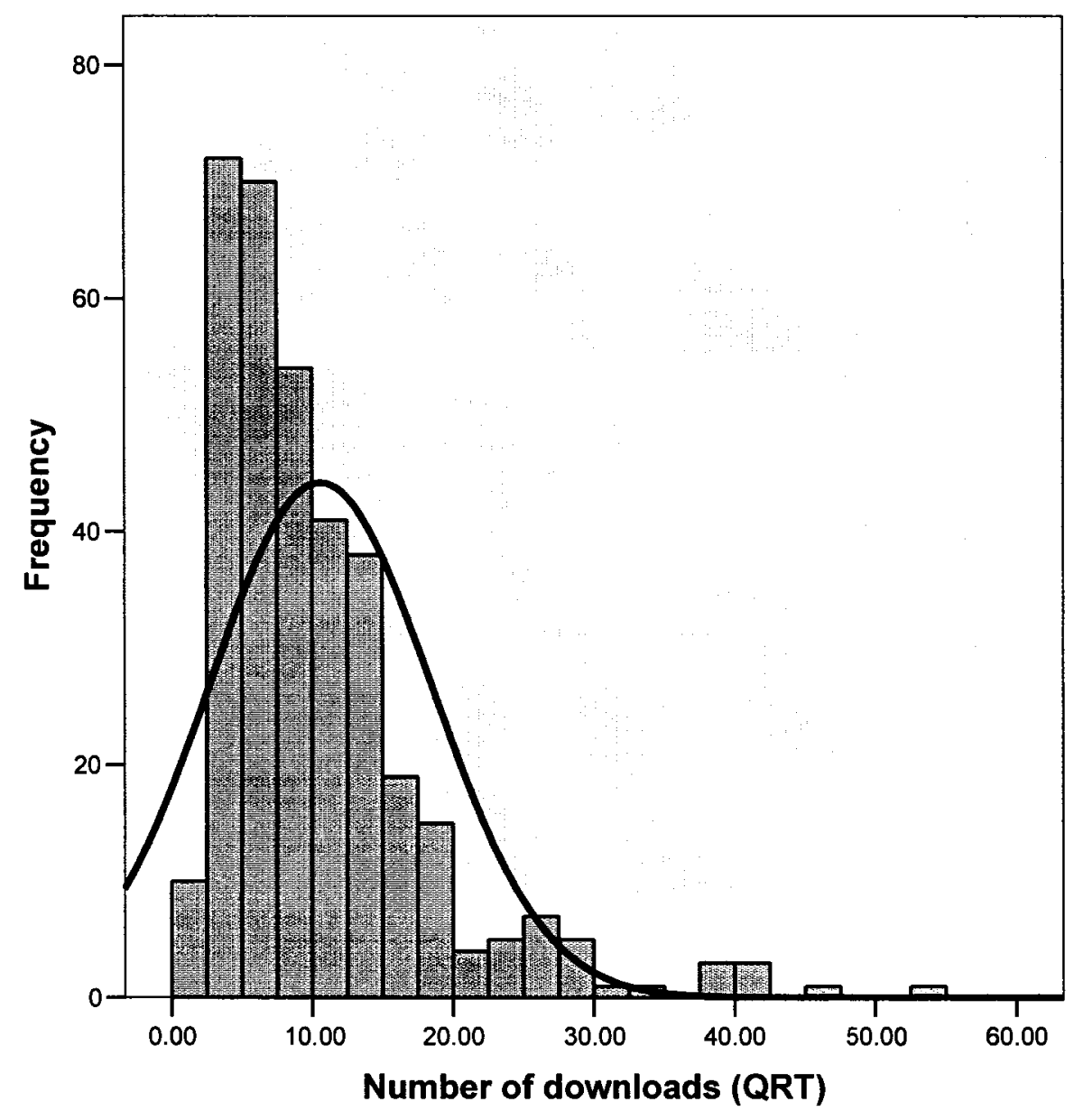

Mean $=10.5832$

Std. Dev. $=7.90422$

$\mathbf{N}=350$ 
Figure 9. Histogram: Number of releases (QRT)

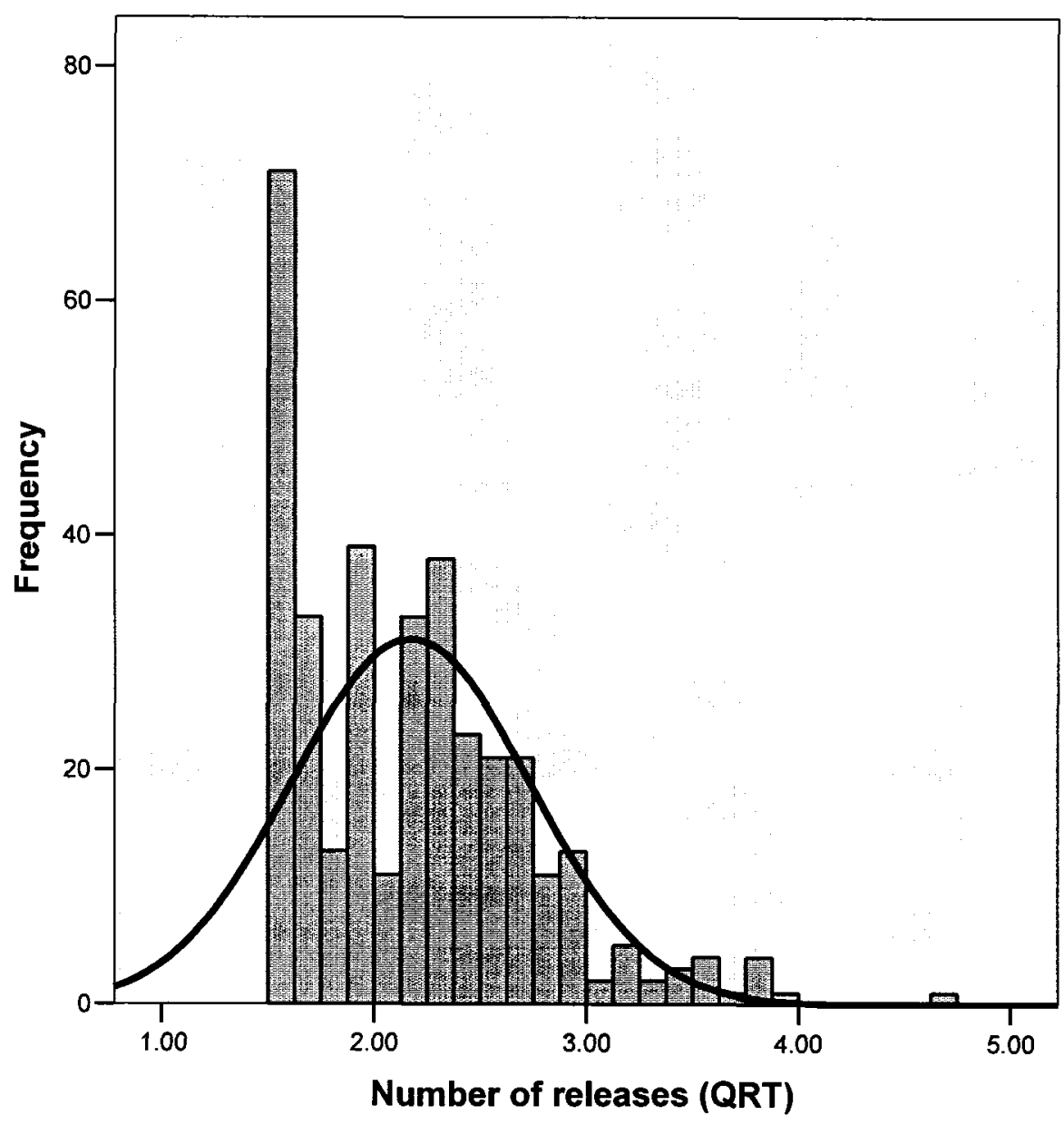

Mean $=2.1723$

Std. Dev. $=0.56122$

$\mathrm{N}=350$

\subsection{Multivariate General Linear Model (GLM)}

Multivariate GLM was used to explore the relationship between the factors assumed to contribute to the OSS project's success and the two measures of OSS project success. 
Prior to using the multivariate GLM to examine the data, the researcher first checked the homogeneity of the variance, homogeneity of the covariance, and the homogeneity of regression.

Levene's test was used to check for the homogeneity of variance. This test assesses whether or not the variance of the number of downloads and number of releases is homogeneous across the target users types, programming language types, software types, and types of license.

Box's M test was used to check for the homogeneity of covariance. This test assesses whether or not the covariance between number of downloads and number of releases is similar across the target users types, programming language types, software types, and types of license.

Homogeneity of regression is a test that assesses whether or not the coefficients (slopes of regression lines) of number of developers and experience of developers are the same for target users types, programming language types, software types, and types of license. Effects of interactions between number of developers, experience of developers and target users type, programming language type, software type, type of license, development status on number of downloads and number of releases were observed.

Table 6 provides the results of the Levene's test. 
Table 6. Levene's test for homogeneity of variances for number of downloads and number of releases across target users types, programming language types, software types, types of license, and development status

$($ Sample size $=350)$

\begin{tabular}{|r|c|c|c|}
\hline & Levene statistic & df1 & df2 \\
\hline $\begin{array}{r}\text { Number of } \\
\text { downloads (QRT) }\end{array}$ & $\begin{array}{c}1.162 \\
.275\end{array}$ & 24 & 325 \\
\hline Number of releases \\
(QRT)
\end{tabular}

The results of Table 6 indicate that the Levene statistic is not significant for number of downloads and number of releases. Therefore, the variance of the number of downloads and number of releases is equal across target user types, programming language types, software types, and license types.

The assumption of homogeneity of variances is met for the number of downloads and number of releases.

Table 7 provides the result of the Box's M test. 
Table 7. Box's $M$ test for homogeneity of covariance between number of downloads and number of releases across target users types, programming language types, software types, types of license, and development status

$($ Sample size $=350)$

\begin{tabular}{|c|c|c|c|}
\hline Box's M & F & df1 & df2 \\
\hline $\begin{array}{c}171.569(* * *) \\
.000\end{array}$ & $\begin{array}{c}3.218(* * *) \\
.000\end{array}$ & 48 & 4581.81 \\
$F^{*} \mathrm{p}<0.10$ & & \\
$* * \mathrm{p}<0.05$ & & \\
$* * * \mathrm{p}<0.01$ & & & \\
\end{tabular}

The results of Table 7 indicate that the Box's M and F statistics are significant (at $p<$ 0.01). Therefore, the covariance between number of downloads and number of releases is not equal across target users types, programming language types, software types, and license types.

The assumption of homogeneity of covariances between the number of downloads and the number of releases is not met. However, GLM is relatively robust against the violation of this assumption when the groups are of not very unequal sample size and the sample size is adequate. Further SPSS adjusts automatically for unequal group sizes.

Table 8 provides the results of the effects of the interactions between the number of developers, years of experience of developers and target user type, programming language type, software type, license type on number of downloads and number of releases. 
Table 8. Interaction effects between number of downloads, number of releases and target users type, programming language type, software type, license type, development status on number of downloads and number of releases

$($ Sample size $=350)$

\begin{tabular}{|c|c|c|c|c|c|c|c|}
\hline \multicolumn{2}{|l|}{ Effect } & Value & $\mathbf{F}$ & $\begin{array}{c}\text { Hypothesis } \\
\text { df }\end{array}$ & $\begin{array}{c}\text { Error } \\
\text { df }\end{array}$ & $\begin{array}{l}\text { Partial } \\
\text { Eta } \\
\text { squared } \\
\text { coefficient }\end{array}$ & $\begin{array}{c}\text { Observed } \\
\text { power }\end{array}$ \\
\hline \multirow{4}{*}{$\begin{array}{r}\text { Target users } \\
\text { type* Number of } \\
\text { developers }\end{array}$} & $\begin{array}{l}\text { Pillai's } \\
\text { trace }\end{array}$ & .003 & $\begin{array}{c}.232 \\
(.920)\end{array}$ & 4 & 646 & .001 & .175 \\
\hline & $\begin{array}{l}\text { Wilk's } \\
\text { lambda }\end{array}$ & .997 & $\begin{array}{l}.231 \\
(.921)\end{array}$ & 4 & 644 & .001 & .175 \\
\hline & $\begin{array}{l}\text { Hotelling's } \\
\text { trace }\end{array}$ & .003 & $\begin{array}{c}.231 \\
(.921)\end{array}$ & 4 & 642 & .001 & .175 \\
\hline & $\begin{array}{l}\text { Roy's } \\
\text { largest root }\end{array}$ & .002 & $\begin{array}{c}.384 \\
(.682)\end{array}$ & 2 & 323 & .001 & .189 \\
\hline \multirow{4}{*}{$\begin{array}{r}\text { Target users } \\
\text { type*Experience } \\
\text { of developers }\end{array}$} & $\begin{array}{l}\text { Pillai's } \\
\text { trace }\end{array}$ & .001 & $\begin{array}{c}.048 \\
(.996)\end{array}$ & 4 & 646 & .000 & .115 \\
\hline & $\begin{array}{l}\text { Wilk's } \\
\text { lambda }\end{array}$ & .999 & $\begin{array}{l}.048 \\
(.996)\end{array}$ & 4 & 644 & .000 & .115 \\
\hline & $\begin{array}{l}\text { Hotelling's } \\
\text { trace }\end{array}$ & .001 & $\begin{array}{c}.048 \\
(.996)\end{array}$ & 4 & 642 & .000 & .115 \\
\hline & $\begin{array}{c}\text { Roy's } \\
\text { largest root }\end{array}$ & .001 & $\begin{array}{c}.092 \\
(.912)\end{array}$ & 2 & 323 & .001 & .121 \\
\hline $\begin{array}{r}\text { Programming } \\
\text { language } \\
\text { type*Number of }\end{array}$ & $\begin{array}{l}\text { Pillai's } \\
\text { trace }\end{array}$ & .006 & $\begin{array}{c}.936 \\
(.393)\end{array}$ & 2 & 322 & .006 & .318 \\
\hline
\end{tabular}




\begin{tabular}{|c|c|c|c|c|c|c|c|}
\hline developers & $\begin{array}{l}\text { Wilk's } \\
\text { lambda }\end{array}$ & .994 & $\begin{array}{c}.936 \\
(.393)\end{array}$ & 2 & 322 & .006 & .318 \\
\hline & $\begin{array}{l}\text { Hotelling's } \\
\text { trace }\end{array}$ & .006 & $\begin{array}{c}.936 \\
(.393)\end{array}$ & 2 & 322 & .006 & .318 \\
\hline & $\begin{array}{c}\text { Roy's } \\
\text { largest root }\end{array}$ & .006 & $\begin{array}{c}.936 \\
(.393)\end{array}$ & 2 & 322 & .006 & .318 \\
\hline \multirow{4}{*}{$\begin{array}{r}\text { Programming } \\
\text { language } \\
\text { type* Experience } \\
\text { of developers }\end{array}$} & $\begin{array}{l}\text { Pillai's } \\
\text { trace }\end{array}$ & .007 & $\begin{array}{l}1.249 \\
(.288)\end{array}$ & 2 & 322 & .007 & .388 \\
\hline & $\begin{array}{l}\text { Wilk's } \\
\text { lambda }\end{array}$ & .993 & $\begin{array}{l}1.249 \\
(.288)\end{array}$ & 2 & 322 & .007 & .388 \\
\hline & $\begin{array}{l}\text { Hotelling's } \\
\text { trace }\end{array}$ & .008 & $\begin{array}{l}1.249 \\
(.288)\end{array}$ & 2 & 322 & .007 & .388 \\
\hline & $\begin{array}{c}\text { Roy's } \\
\text { largest root }\end{array}$ & .008 & $\begin{array}{l}1.249 \\
(.288)\end{array}$ & 2 & 322 & .007 & .388 \\
\hline \multirow{4}{*}{$\begin{array}{r}\text { Software } \\
\text { type }{ }^{*} \text { Number of } \\
\text { developers }\end{array}$} & $\begin{array}{l}\text { Pillai's } \\
\text { trace }\end{array}$ & .002 & $\begin{array}{c}.126 \\
(.973)\end{array}$ & 4 & 646 & .001 & .140 \\
\hline & $\begin{array}{l}\text { Wilk's } \\
\text { lambda }\end{array}$ & .998 & $\begin{array}{c}.126 \\
(.973)\end{array}$ & 4 & 644 & .001 & .140 \\
\hline & $\begin{array}{l}\text { Hotelling's } \\
\text { trace }\end{array}$ & .002 & $\begin{array}{c}.126 \\
(.973)\end{array}$ & 4 & 642 & .001 & .140 \\
\hline & $\begin{array}{c}\text { Roy's } \\
\text { largest root }\end{array}$ & .002 & $\begin{array}{c}.253 \\
(.777)\end{array}$ & 2 & 323 & .002 & .159 \\
\hline $\begin{array}{r}\text { Software } \\
\text { type }{ }^{*} \text { Experience } \\
\text { of developers }\end{array}$ & $\begin{array}{l}\text { Pillai's } \\
\text { trace }\end{array}$ & .002 & $\begin{array}{c}.160 \\
(.958)\end{array}$ & 4 & 646 & .001 & .151 \\
\hline
\end{tabular}




\begin{tabular}{|c|c|c|c|c|c|c|c|}
\hline & $\begin{array}{l}\text { Wilk's } \\
\text { lambda }\end{array}$ & .998 & $\begin{array}{l}.160 \\
(.958)\end{array}$ & 4 & 644 & .001 & .151 \\
\hline & $\begin{array}{l}\text { Hotelling's } \\
\text { trace }\end{array}$ & .002 & $\begin{array}{l}.160 \\
(.958)\end{array}$ & 4 & 642 & .001 & .151 \\
\hline & $\begin{array}{c}\text { Roy's } \\
\text { largest root }\end{array}$ & .002 & $\begin{array}{l}.291 \\
(.748)\end{array}$ & 2 & 323 & .002 & .168 \\
\hline \multirow{4}{*}{$\begin{array}{r}\text { Type of } \\
\text { license* Number } \\
\text { of developers }\end{array}$} & $\begin{array}{l}\text { Pillai's } \\
\text { trace }\end{array}$ & .022 & $\begin{array}{l}1.848 \\
.118\end{array}$ & 4 & 646 & .011 & .684 \\
\hline & $\begin{array}{l}\text { Wilk's } \\
\text { lambda }\end{array}$ & .978 & $\begin{array}{c}1.849 \\
.118\end{array}$ & 4 & 644 & .011 & .684 \\
\hline & $\begin{array}{l}\text { Hotelling's } \\
\text { trace }\end{array}$ & .022 & $\begin{array}{c}1.849 \\
.118\end{array}$ & 4 & 642 & .011 & .684 \\
\hline & $\begin{array}{c}\text { Roy's } \\
\text { largest root }\end{array}$ & .022 & $\begin{array}{c}3.286 \\
.109\end{array}$ & 2 & 323 & .019 & .736 \\
\hline \multirow{4}{*}{$\begin{array}{r}\text { Type of } \\
\text { license* Experienc } \\
\text { e of developers }\end{array}$} & $\begin{array}{l}\text { Pillai's } \\
\text { trace }\end{array}$ & .016 & $\begin{array}{c}1.327 \\
.258\end{array}$ & 4 & 646 & .008 & .545 \\
\hline & $\begin{array}{l}\text { Wilk's } \\
\text { lambda }\end{array}$ & .984 & $\begin{array}{c}1.328 \\
.258\end{array}$ & 4 & 644 & .008 & .546 \\
\hline & $\begin{array}{l}\text { Hotelling's } \\
\text { trace }\end{array}$ & .016 & $\begin{array}{c}1.329 \\
.258\end{array}$ & 4 & 642 & .008 & .546 \\
\hline & $\begin{array}{c}\text { Roy's } \\
\text { largest root }\end{array}$ & .016 & $\begin{array}{c}2.616 \\
.175\end{array}$ & 2 & 323 & .015 & .644 \\
\hline $\begin{array}{r}\text { Development } \\
\text { status }{ }^{*} \text { Number of } \\
\text { developers }\end{array}$ & $\begin{array}{l}\text { Pillai's } \\
\text { trace }\end{array}$ & .011 & $\begin{array}{l}.897 \\
.465\end{array}$ & 10 & 646 & .006 & .407 \\
\hline
\end{tabular}




\begin{tabular}{|c|c|c|c|c|c|c|c|}
\hline & $\begin{array}{l}\text { Wilk's } \\
\text { lambda }\end{array}$ & .989 & $\begin{array}{l}.897 \\
.465\end{array}$ & 10 & 644 & .006 & .407 \\
\hline & $\begin{array}{l}\text { Hotelling's } \\
\text { trace }\end{array}$ & .011 & $\begin{array}{l}.897 \\
.465\end{array}$ & 10 & 642 & .006 & .407 \\
\hline & $\begin{array}{c}\text { Roy's } \\
\text { largest root }\end{array}$ & .011 & $\begin{array}{c}1.774 \\
.171\end{array}$ & 5 & 323 & .011 & .497 \\
\hline \multirow{4}{*}{$\begin{array}{r}\text { Development } \\
\text { status* Experienc } \\
\text { e of developers }\end{array}$} & $\begin{array}{l}\text { Pillai's } \\
\text { trace }\end{array}$ & .027 & $\begin{array}{l}.882 \\
.550\end{array}$ & 10 & 646 & .013 & .603 \\
\hline & $\begin{array}{l}\text { Wilk's } \\
\text { lambda }\end{array}$ & .973 & $\begin{array}{l}.881 \\
.551\end{array}$ & 10 & 644 & .013 & .603 \\
\hline & $\begin{array}{l}\text { Hotelling's } \\
\text { trace }\end{array}$ & .075 & $\begin{array}{l}.880 \\
.552\end{array}$ & 10 & 642 & .014 & .602 \\
\hline & $\begin{array}{c}\text { Roy's } \\
\text { largest root }\end{array}$ & .021 & $\begin{array}{c}1.357 \\
.240\end{array}$ & 5 & 323 & .021 & .607 \\
\hline $\begin{array}{rr}{ }^{*} \mathrm{p} & <0.10 \\
* * \mathrm{p} & <0.05 \\
* * * \mathrm{p} & <0.01\end{array}$ & & & & & & & \\
\hline
\end{tabular}

The results shown in Table 8 indicate that the interaction effects between number of developers, experience of developers and type of target users, programming language type, software type, type of license, development status on number of downloads and number of releases are not significant because the values of Pillai's trace, Wilk's lambda, Hotelling's trace, Roy's largest root and F statistics for these are not significant.

Furthermore the observed power is also less, which should be closer to 1 for significance. Therefore, the coefficients (slopes of regression lines) of number of developers and experience of developers are the same for target user types, programming language types, 
software types, license types, and development status. Hence, the assumption of homogeneity of regression is met.

Table 9 provides the results of using the multivariate GLM to examine the data. The effect of all independent variables: number of developers, experience of developers, target users type, programming language type, software type, type of license, and development status were observed simultaneously on the two dependent variables: number of downloads and number of releases. Pillai's trace, Wilk's lambda, Hotelling's trace, and Roy's largest root tests were used to assess the strength of the relationships.

Table 9. Multivariate GLM tests

$($ Sample size $=350)$

\begin{tabular}{|c|c|c|c|c|c|c|c|}
\hline \multicolumn{2}{|l}{} & Value & F & $\begin{array}{c}\text { Hypothesis } \\
\text { df }\end{array}$ & $\begin{array}{c}\text { Error } \\
\text { df }\end{array}$ & $\begin{array}{c}\text { Partial } \\
\text { Eta } \\
\text { squared } \\
\text { coefficient }\end{array}$ & $\begin{array}{c}\text { Observed } \\
\text { power }\end{array}$ \\
\hline & Pillai's trace & .924 & $\begin{array}{c}2048.35(* * *) \\
(.000)\end{array}$ & 2 & 336 & .924 & 1 \\
\cline { 2 - 8 } Intercept & $\begin{array}{c}\text { Wilk's } \\
\text { lambda }\end{array}$ & $\begin{array}{c}.076 \\
\text { Hotelling's } \\
\text { trace }\end{array}$ & $\begin{array}{c}2048.35(* * *) \\
(.000)\end{array}$ & 2 & 336 & .924 & 1 \\
\cline { 2 - 8 } & $\begin{array}{c}.2 .193 \\
\text { Roy's } \\
\text { largest root }\end{array}$ & 12.193 & $\begin{array}{c}2048.35(* * *) \\
(.000) \\
(.000)\end{array}$ & 2 & 336 & .924 & 1 \\
\hline
\end{tabular}




\begin{tabular}{|c|c|c|c|c|c|c|c|}
\hline \multirow{4}{*}{$\begin{array}{l}\text { Number of } \\
\text { developers }\end{array}$} & Pillai's trace & .019 & $\begin{array}{c}3.27\left({ }^{* *}\right) \\
(.039)\end{array}$ & 2 & 334 & .019 & .734 \\
\hline & $\begin{array}{l}\text { Wilk's } \\
\text { lambda }\end{array}$ & .971 & $\begin{array}{c}3.27(* *) \\
(.039)\end{array}$ & 2 & 334 & .019 & .734 \\
\hline & $\begin{array}{l}\text { Hotelling's } \\
\text { trace }\end{array}$ & .020 & $\begin{array}{c}3.27(* *) \\
(.039)\end{array}$ & 2 & 334 & .019 & .734 \\
\hline & $\begin{array}{l}\text { Roy's } \\
\text { largest root }\end{array}$ & .020 & $\begin{array}{c}3.27(* *) \\
(.039)\end{array}$ & 2 & 334 & .019 & .734 \\
\hline \multirow{4}{*}{$\begin{array}{r}\text { Experience of } \\
\text { developers }\end{array}$} & Pillai's trace & .023 & $\begin{array}{c}3.63(* *) \\
(.018)\end{array}$ & 2 & 334 & .021 & .860 \\
\hline & $\begin{array}{l}\text { Wilk's } \\
\text { lambda }\end{array}$ & .969 & $\begin{array}{c}3.63(* *) \\
(.018)\end{array}$ & 2 & 334 & .021 & .860 \\
\hline & $\begin{array}{l}\text { Hotelling's } \\
\text { trace }\end{array}$ & .023 & $\begin{array}{c}3.63\left(^{* *}\right) \\
(.018)\end{array}$ & 2 & 334 & .021 & .860 \\
\hline & $\begin{array}{c}\text { Roy's } \\
\text { largest root }\end{array}$ & .023 & $\begin{array}{c}3.63\left(^{* *}\right) \\
(.018)\end{array}$ & 2 & 334 & .021 & .860 \\
\hline \multirow{4}{*}{$\begin{array}{r}\text { Target users } \\
\text { type }\end{array}$} & Pillai's trace & .029 & $\begin{array}{c}2.43(* *) \\
(.047)\end{array}$ & 4 & 670 & .014 & .720 \\
\hline & $\begin{array}{l}\text { Wilk's } \\
\text { lambda }\end{array}$ & .972 & $\begin{array}{c}2.43(* *) \\
(.047)\end{array}$ & 4 & 668 & .014 & .720 \\
\hline & $\begin{array}{l}\text { Hotelling's } \\
\text { trace }\end{array}$ & .029 & $\begin{array}{c}2.43(* *) \\
(.047)\end{array}$ & 4 & 666 & .014 & .720 \\
\hline & $\begin{array}{l}\text { Roy's } \\
\text { largest root }\end{array}$ & .020 & $\begin{array}{c}3.31(* *) \\
(.038)\end{array}$ & 2 & 335 & .019 & .737 \\
\hline
\end{tabular}




\begin{tabular}{|c|c|c|c|c|c|c|c|}
\hline \multirow{4}{*}{$\begin{array}{l}\text { Programming } \\
\text { language type }\end{array}$} & Pillai's trace & .010 & $\begin{array}{c}1.66 \\
(.192)\end{array}$ & 2 & 334 & .010 & .474 \\
\hline & $\begin{array}{l}\text { Wilk's } \\
\text { lambda }\end{array}$ & .990 & $\begin{array}{c}1.66 \\
(.192)\end{array}$ & 2 & 334 & .010 & .474 \\
\hline & $\begin{array}{l}\text { Hotelling's } \\
\text { trace }\end{array}$ & .010 & $\begin{array}{c}1.66 \\
(.192)\end{array}$ & 2 & 334 & .010 & .474 \\
\hline & $\begin{array}{c}\text { Roy's } \\
\text { largest root }\end{array}$ & .010 & $\begin{array}{c}1.66 \\
(.192)\end{array}$ & 2 & 334 & .010 & .474 \\
\hline \multirow{4}{*}{ Software type } & Pillai's trace & .040 & $\begin{array}{c}3.45(* * *) \\
(.009)\end{array}$ & 4 & 670 & .022 & .917 \\
\hline & $\begin{array}{l}\text { Wilk's } \\
\text { lambda }\end{array}$ & .960 & $\begin{array}{c}3.45(* * *) \\
(.009)\end{array}$ & 4 & 668 & .022 & .917 \\
\hline & $\begin{array}{l}\text { Hotelling's } \\
\text { trace }\end{array}$ & .042 & $\begin{array}{c}3.45(* * *) \\
(.009)\end{array}$ & 4 & 666 & .022 & .917 \\
\hline & $\begin{array}{c}\text { Roy's } \\
\text { largest root }\end{array}$ & .039 & $\begin{array}{c}6.45(* * 8) \\
(.002)\end{array}$ & 2 & 335 & .026 & .947 \\
\hline \multirow{4}{*}{$\begin{array}{l}\text { Type of } \\
\text { license }\end{array}$} & Pillai's trace & .021 & $\begin{array}{l}1.810 \\
(.125)\end{array}$ & 4 & 670 & .011 & .675 \\
\hline & $\begin{array}{l}\text { Wilk's } \\
\text { lambda }\end{array}$ & .980 & $\begin{array}{l}1.813 \\
(.125)\end{array}$ & 4 & 668 & .011 & .675 \\
\hline & $\begin{array}{l}\text { Hotelling's } \\
\text { trace }\end{array}$ & .022 & $\begin{array}{l}1.815 \\
(.124)\end{array}$ & 4 & 666 & .011 & .676 \\
\hline & $\begin{array}{c}\text { Roy's } \\
\text { largest root }\end{array}$ & .021 & $\begin{array}{l}1.913 \\
(.114)\end{array}$ & 2 & 335 & .012 & .690 \\
\hline
\end{tabular}




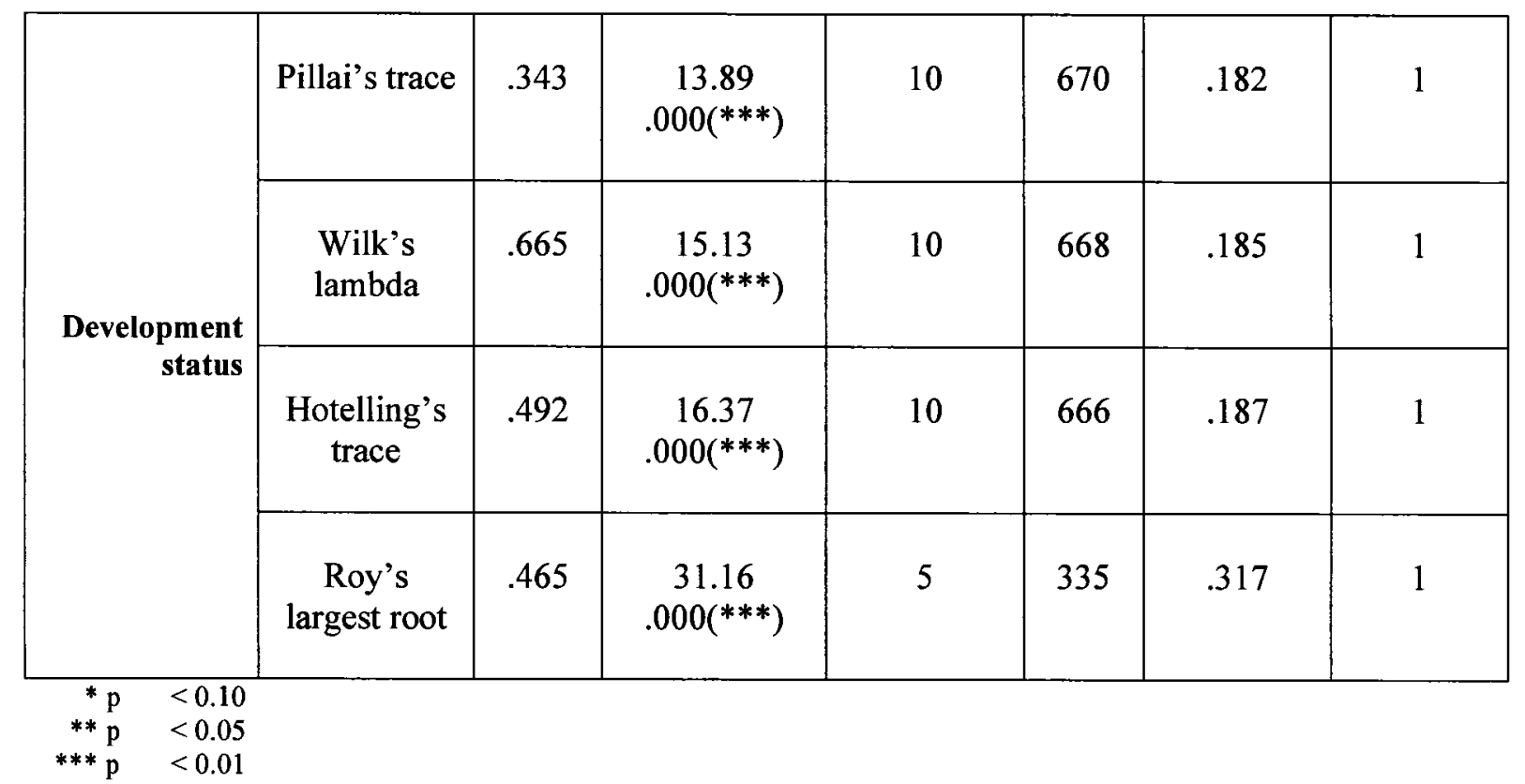

The results of Table 9 indicate the following.

- The effect of number of developers on number of downloads and number of releases is significant because the Pillai's trace, Wilk's lambda, Hotelling's trace, Roy's largest root and $\mathrm{F}$ statistics for these are significant (at $\mathrm{p}<0.05$ ) with coefficient .019 and observed power equal to 0.734 .

- The effect of experience of developers on number of downloads and number of releases is significant because the Pillai's trace, Wilk's lambda, Hotelling's trace, Roy's largest root and F statistics for these are significant (at $\mathrm{p}<0.05$ ) with coefficient .021 and observed power equal to 0.860 .

- The effect of target users type on number of downloads and number of releases is significant because the Pillai's trace, Wilk's lambda, Hotelling's trace and F statistics for these are significant (at $p<0.05$ ) with coefficient .014 and observed power equal to 0.720 . Roy's largest root and its $\mathrm{F}$ statistic is significant (at $\mathrm{p}<$ 
0.05 ) with coefficient .019 and observed power equal to 0.737 . Due to the significance of F statistics the null Hypothesis that average number of downloads and releases are the same for all types of targeted users can be rejected.

- The effect of programming language type on number of downloads and number of releases is not significant because the Pillai's trace, Wilk's lambda, Hotelling's trace, Roy's largest root and F statistics for these are not significant. Therefore, the null Hypothesis that average number of downloads and releases are the same for all types of programming languages cannot be rejected.

- The effect of software type on number of downloads and number of releases is significant because the Pillai's trace, Wilk's lambda, Hotelling's trace and F statistics for these are significant (at $\mathrm{p}<0.01$ ) with coefficient .022 and observed power equal to 0.917 . Roy's largest root and its F statistic is significant (at $\mathrm{p}<$ 0.05 ) with coefficient .026 and observed power equal to 0.947 . Due to the significance of F statistics the null Hypothesis that average number of downloads and releases is the same for all types of software can be rejected.

- The effect of type of license on number of downloads and number of releases is not significant because the Pillai's trace, Wilk's lambda, Hotelling's trace, Roy's largest root and F statistics for these are not significant. Therefore, the null Hypothesis that average number of downloads and releases are the same for all types of license cannot be rejected.

- The effect development status on number of downloads and number of releases is significant because the Pillai's trace, Wilk's lambda, Hotelling's trace and F statistics for these are significant (at $p<0.01$ ) with coefficient .18 and observed 
power equal to 1 . Roy's largest root and its F statistic is significant (at $p<0.01$ ) with coefficient .317 and observed power equal to 1 .

Results in Table 9 suggest that the number of developers, experience of developers, target users type, software type and development status significantly affect number of downloads and number of releases. However, programming language type and license type used did not significantly affect number of downloads and number of releases.

The Partial Eta square coefficient estimates the effect size of an independent variable on the dependent variable. Ranking the five independent variables that significantly affect the dependent variables using their Partial Eta squared coefficients shown in Table 9, provides the following results: 1 . development status (.182 to .317$)$, 2. software type (0.022), 3. experience of developers $(0.021), 4$. number of developers $(0.019)$ and 5 . targeting developers as users $(0.014)$.

The ranking above suggests that:

- the effect of development status on number of downloads and number of releases is significant

- software type, experience of developers, and number of developers affect number of downloads and number of releases more than targeting developers as users 
Table 10 provides multiple comparison results of the Bonferroni test. It was used to compare average number of downloads across the types of target users because it assumes equal variances. Results shown in Table 10 indicate that the average number of downloads is greater if the target users of the OSS project are developers instead of system administrators and end users. The results are significant at $p<0.05$. However, the difference between average number of downloads is not significant when target users of the OSS projects are either system administrators or end users.

Table 11 provides multiple comparison results of the Bonferroni test. It was used to compare average number of releases across the types of target users because it assumes equal variances.

Results of Table 11 indicate that average number of releases is greater if the target users of the OSS project are developers instead of system administrators and end users. The results are significant at $\mathrm{p}<0.01$. Moreover, the average number of releases is greater if the target users of the OSS software project are system administrators instead of end users. The results are significant at $\mathrm{p}<0.05$. 
Table 10. Multiple comparisons of average number of downloads across types of target users

$($ Sample size $=350)$

Number of downloads (QRT)

\begin{tabular}{|c|c|c|c|c|c|}
\hline \multirow{2}{*}{$\begin{array}{c}\text { (I) Target users } \\
\text { type }\end{array}$} & \multirow{2}{*}{ Mean } & \multirow{2}{*}{$\begin{array}{c}\text { (J) Target users } \\
\text { type }\end{array}$} & \multirow{2}{*}{$\begin{array}{c}\text { Mean } \\
\text { difference } \\
\text { (I-J) }\end{array}$} & \multicolumn{2}{|c|}{$\begin{array}{c}90 \% \text { Confidence } \\
\text { interval }\end{array}$} \\
\hline & & & & $\begin{array}{l}\text { Lower } \\
\text { bound }\end{array}$ & $\begin{array}{l}\text { Upper } \\
\text { bound }\end{array}$ \\
\hline \multirow{2}{*}{ Developers } & \multirow{2}{*}{12.2315} & $\begin{array}{c}\text { System } \\
\text { administrators }\end{array}$ & $\begin{array}{l}2.4035(*) \\
.075\end{array}$ & .1214 & 4.6855 \\
\hline & & End users & $\begin{array}{c}2.3861(* *) \\
.050\end{array}$ & .2232 & 4.5490 \\
\hline \multirow{2}{*}{$\begin{array}{c}\text { System } \\
\text { administrators }\end{array}$} & \multirow{2}{*}{9.8280} & Developers & $\begin{array}{c}-2.4035\left(^{*}\right) \\
.075\end{array}$ & -4.6855 & -.1214 \\
\hline & & End users & $\begin{array}{l}-.0174 \\
(1.000)\end{array}$ & -2.1913 & 2.1566 \\
\hline \multirow{2}{*}{ End users } & \multirow{2}{*}{9.8454} & Developers & $\begin{array}{c}-2.3861(* *) \\
.050\end{array}$ & -4.5490 & -.2232 \\
\hline & & $\begin{array}{c}\text { System } \\
\text { administrators }\end{array}$ & $\begin{array}{c}.0174 \\
(1.000)\end{array}$ & -2.1566 & 2.1913 \\
\hline $\begin{array}{rr}{ }^{*} \mathrm{p} & <0.10 \\
{ }^{* *} \mathrm{p} & <0.05 \\
* * * \mathrm{p} & <0.01\end{array}$ & & & & & \\
\hline
\end{tabular}


Table 11. Multiple comparisons of average number of releases across types of target users

$($ Sample size $=350)$

Number of releases (QRT)

\begin{tabular}{|c|c|c|c|c|c|}
\hline \multirow{2}{*}{$\begin{array}{c}\text { (I) Target users } \\
\text { type }\end{array}$} & \multirow{2}{*}{ Mean } & \multirow{2}{*}{$\begin{array}{c}\text { (J) Target users } \\
\text { type }\end{array}$} & \multirow{2}{*}{$\begin{array}{c}\text { Mean } \\
\text { difference } \\
\text { (I-J) }\end{array}$} & \multicolumn{2}{|c|}{$\begin{array}{c}90 \% \text { Confidence } \\
\text { interval }\end{array}$} \\
\hline & & & & $\begin{array}{l}\text { Lower } \\
\text { bound }\end{array}$ & $\begin{array}{l}\text { Upper } \\
\text { bound }\end{array}$ \\
\hline \multirow{2}{*}{ Developers } & \multirow{2}{*}{2.3992} & $\begin{array}{c}\text { System } \\
\text { administrators }\end{array}$ & $\begin{array}{c}.2352(* * *) \\
.004\end{array}$ & .0791 & .3914 \\
\hline & & End users & $\begin{array}{c}.4047(* * *) \\
.000\end{array}$ & .2567 & .5527 \\
\hline \multirow{2}{*}{$\begin{array}{c}\text { System } \\
\text { administrators }\end{array}$} & \multirow{2}{*}{2.1639} & Developers & $\begin{array}{c}-.2352(* * *) \\
.004\end{array}$ & -.3914 & -.0791 \\
\hline & & End users & $\begin{array}{c}.1694(* *) \\
.046\end{array}$ & .0207 & .3182 \\
\hline \multirow{2}{*}{ End users } & \multirow{2}{*}{1.9945} & Developers & $\begin{array}{c}-.4047(* * *) \\
.000\end{array}$ & -.5527 & -.2567 \\
\hline & & $\begin{array}{c}\text { System } \\
\text { administrators }\end{array}$ & $\begin{array}{c}-.1694(* *) \\
.046\end{array}$ & -.3182 & -.0207 \\
\hline $\begin{array}{rr}{ }^{*} \mathrm{p} & <0.10 \\
* * \mathrm{p} & <0.05 \\
* * * \mathrm{p} & <0.01\end{array}$ & & & & & \\
\hline
\end{tabular}


Table 12 provides multiple comparison results of Bonferroni test. It was used to compare average number of downloads across the types of software because it assumes equal variances.

The results shown in Table 12 indicate that the average number of downloads is greater if the application development and deployment tools are developed instead of system infrastructure software and application software. The results are significant at $\mathrm{p}<0.01$. However, the difference between average number of downloads is not significant when the type of OSS software is either system infrastructure software or application software. 
Table 12. Multiple comparisons of average number of downloads across types of software

$($ Sample size $=350)$

Number of downloads (QRT)

\begin{tabular}{|c|c|c|c|c|c|}
\hline \multirow[b]{2}{*}{$\begin{array}{l}\text { (I) Type of } \\
\text { software }\end{array}$} & \multirow[b]{2}{*}{ Mean } & \multirow[b]{2}{*}{$\begin{array}{l}\text { (J) Type of } \\
\text { software }\end{array}$} & \multirow[b]{2}{*}{$\begin{array}{c}\text { Mean } \\
\text { difference } \\
\text { (I-J) }\end{array}$} & \multicolumn{2}{|c|}{$\begin{array}{c}90 \% \text { Confidence } \\
\text { interval }\end{array}$} \\
\hline & & & & $\begin{array}{l}\text { Lower } \\
\text { bound }\end{array}$ & $\begin{array}{l}\text { Upper } \\
\text { bound }\end{array}$ \\
\hline \multirow{2}{*}{$\begin{array}{l}\text { Application } \\
\text { software }\end{array}$} & \multirow[t]{2}{*}{9.3579} & $\begin{array}{c}\text { Application } \\
\text { development and } \\
\text { deployment } \\
\text { tools } \\
\end{array}$ & $\begin{array}{c}- \\
3.0662(* * *) \\
.008\end{array}$ & -5.2402 & -.8922 \\
\hline & & $\begin{array}{c}\text { System } \\
\text { infrastructure } \\
\text { software }\end{array}$ & $\begin{array}{l}-.8448 \\
1.000\end{array}$ & -3.0029 & 1.3134 \\
\hline \multirow{2}{*}{$\begin{array}{c}\text { Application } \\
\text { development and } \\
\text { deployment tools }\end{array}$} & \multirow{2}{*}{12.4242} & $\begin{array}{l}\text { Application } \\
\text { software }\end{array}$ & $\begin{array}{c}3.0662(* * *) \\
.008\end{array}$ & .8922 & 5.2402 \\
\hline & & $\begin{array}{c}\text { System } \\
\text { infrastructure } \\
\text { software }\end{array}$ & $\begin{array}{l}2.2215 \\
.106\end{array}$ & -.0268 & 4.4697 \\
\hline \multirow{2}{*}{$\begin{array}{c}\text { System } \\
\text { infrastructure } \\
\text { software }\end{array}$} & \multirow{2}{*}{10.2027} & $\begin{array}{l}\text { Application } \\
\text { software }\end{array}$ & $\begin{array}{l}.8448 \\
1.000\end{array}$ & -1.3134 & 3.0029 \\
\hline & & $\begin{array}{c}\text { Application } \\
\text { development and } \\
\text { deployment } \\
\text { tools }\end{array}$ & $\begin{array}{l}-2.2215 \\
.106\end{array}$ & -4.4697 & .0268 \\
\hline $\begin{aligned}{ }^{*} \mathrm{p} & <0.10 \\
* * \mathrm{p} & <0.05 \\
* * * \mathrm{p} & <0.01\end{aligned}$ & & & & & \\
\hline
\end{tabular}

Table 13 provides multiple comparison results of Bonferroni test. It was used to compare average number of releases across the types of software because it assumes equal variances. 
Table 13. Multiple comparisons of average number of releases across software types

$($ Sample size $=350)$

Number of releases (QRT)

\begin{tabular}{|c|c|c|c|c|c|}
\hline \multirow[b]{2}{*}{$\begin{array}{l}\text { (I) Type of } \\
\text { software }\end{array}$} & \multirow[b]{2}{*}{ Mean } & \multirow[b]{2}{*}{$\begin{array}{l}\text { (J) Type of } \\
\text { software }\end{array}$} & \multirow[b]{2}{*}{$\begin{array}{c}\text { Mean } \\
\text { difference } \\
(I-J)\end{array}$} & \multicolumn{2}{|c|}{$\begin{array}{c}90 \% \text { Confidence } \\
\text { interval }\end{array}$} \\
\hline & & & & $\begin{array}{l}\text { Lower } \\
\text { bound }\end{array}$ & $\begin{array}{l}\text { Upper } \\
\text { bound }\end{array}$ \\
\hline \multirow{2}{*}{$\begin{array}{l}\text { Application } \\
\text { software }\end{array}$} & \multirow[t]{2}{*}{1.9711} & $\begin{array}{c}\text { Application } \\
\text { development and } \\
\text { deployment } \\
\text { tools }\end{array}$ & $\begin{array}{c}-.4529(* * *) \\
.000\end{array}$ & -.6005 & -.3054 \\
\hline & & $\begin{array}{c}\text { System } \\
\text { infrastructure } \\
\text { software }\end{array}$ & $\begin{array}{c}-.1881(* *) \\
.019\end{array}$ & -.3346 & -.0416 \\
\hline \multirow{2}{*}{$\begin{array}{c}\text { Application } \\
\text { development and } \\
\text { deployment tools }\end{array}$} & \multirow{2}{*}{2.4240} & $\begin{array}{l}\text { Application } \\
\text { software }\end{array}$ & $\begin{array}{c}.4529(* * *) \\
.000\end{array}$ & .3054 & .6005 \\
\hline & & $\begin{array}{c}\text { System } \\
\text { infrastructure } \\
\text { software }\end{array}$ & $\begin{array}{c}.2648(* * *) \\
.001\end{array}$ & .1122 & .4174 \\
\hline \multirow{2}{*}{$\begin{array}{c}\text { System } \\
\text { infrastructure } \\
\text { software }\end{array}$} & \multirow{2}{*}{2.1592} & $\begin{array}{l}\text { Application } \\
\text { software }\end{array}$ & $\begin{array}{c}.1881(* *) \\
.019\end{array}$ & .0416 & .3346 \\
\hline & & $\begin{array}{c}\text { Application } \\
\text { development and } \\
\text { deployment } \\
\text { tools }\end{array}$ & $\begin{array}{c}-.2648(* * *) \\
.001\end{array}$ & -.4174 & -.1122 \\
\hline $\begin{aligned} *{ }_{*} \mathrm{p} & <0.10 \\
* * \mathrm{p} & <0.05 \\
* * * \mathrm{p} & <0.01\end{aligned}$ & & & & & \\
\hline
\end{tabular}

The results shown in Table 13 suggest that the average number of releases is greater if the application development and deployment tools are developed instead of system infrastructure software and application software. The results are significant at $p<0.01$. 
Moreover, the average number of releases is greater if the system infrastructure software is developed instead of application software. The results are significant at $p<0.05$.

\subsection{Hypothesis 1. Number of developers is positively associated with the success of OSS projects}

Hypotheses $1 \mathrm{a}$ and $1 \mathrm{~b}$ posit that number of developers is positively associated with the number of downloads and number of releases of the OSS project respectively.

The results shown in Table 9 provide support for Hypotheses $1 \mathrm{a}$ and $1 \mathrm{~b}$. Spearman correlation was also used to test Hypotheses $1 \mathrm{a}$ and $1 \mathrm{~b}$. Table 14 provides the Spearman correlation coefficients for the number of developers, the number of downloads, and number of releases of OSS projects.

Table 14. Spearman correlation between number of developers and measures of success of OSS development project

$($ Sample size $=350)$

\begin{tabular}{|c|c|c|}
\hline & $\begin{array}{c}\text { Number of downloads } \\
(\mathbf{Q R T})\end{array}$ & $\begin{array}{c}\text { Number of releases } \\
(\mathbf{Q R T})\end{array}$ \\
\hline Number of developers & $.621\left(^{* * *}\right)$ & $.597\left(^{* * *}\right)$ \\
& .000 & .000 \\
\hline$* \mathrm{p} \quad<0.10$ (1-tailed) & & \\
$* * \mathrm{p} \quad<0.05$ (1-tailed) & & \\
$* * * \mathrm{p} \quad<0.01$ (1-tailed) & &
\end{tabular}

One tailed tests of the alternative Hypothesis at $\mathrm{p}<0.01$ showed the following associations: 
- Number of developers is positively associated with the number of downloads of the OSS project

- Number of developers is positively associated with the number of releases of the OSS project

Results shown in Table 14 also support Hypotheses 1a and $1 \mathrm{~b}$.

\subsection{Hypothesis 2. Experience of developers is positively associated with the success of OSS projects}

Hypotheses $2 \mathrm{a}$ and $2 \mathrm{~b}$ posit that the years of experience of developers is positively associated with the number of downloads and number of releases of the OSS project respectively.

The results shown in Table 9 provide support for Hypotheses $2 \mathrm{a}$ and $2 \mathrm{~b}$. Spearman correlation was also used to test Hypotheses $2 \mathrm{a}$ and $2 \mathrm{~b}$. Table 15 provides the Spearman correlation coefficients for years of experience of developers, number of downloads and number of releases of OSS projects. 
Table 15. Spearman correlation between experience of developers and measures of success of OSS development project

$($ Sample size $=350)$

\begin{tabular}{|c|c|c|}
\hline & $\begin{array}{c}\text { Number of downloads } \\
(\text { QRT })\end{array}$ & $\begin{array}{c}\text { Number of releases } \\
(\mathbf{Q R T})\end{array}$ \\
\hline Experience of developers & $.622\left(^{* * *}\right)$ & $.563(* * *)$ \\
.000 & .000 \\
\hline
\end{tabular}

$\begin{array}{rr}* \mathrm{p} & <0.10(1 \text {-tailed }) \\ * * \mathrm{p} & <0.05(1-\text { tailed })\end{array}$

$* * * \mathrm{p} \quad<0.01$ (1-tailed)

One tailed tests of the alternative Hypothesis at $\mathrm{p}<0.01$ showed the following associations:

- Years of experience of developers is positively associated with the number of downloads of the OSS project

- Years of experience of developers is positively associated with the number of releases of the OSS project

Results shown in Table 15 also provide support for Hypotheses $2 \mathrm{a}$ and $2 \mathrm{~b}$.

5.6 Hypothesis 3. Targeting developers as users is positively associated with the success of OSS projects

Hypotheses $3 \mathrm{a}$ and $3 \mathrm{~b}$ posit that targeting developers as users is positively associated with the number of downloads and the number of releases of the OSS project respectively. 
The results shown in Table 9 provide support for Hypotheses $3 \mathrm{a}$ and $3 \mathrm{~b}$. To test hypotheses $3 a$ and $3 b$, the researcher first checked whether or not the variance of the number of downloads and the number of releases is homogeneous across the types of target users. The Levene test of homogeneity of variances was used for this purpose. Table 16 provides the results.

Table 16. Levene test for homogeneity of variances for number of downloads and number of releases across types of target users

$($ Sample size $=350)$

\begin{tabular}{|c|c|c|c|}
\hline & Levene statistic & df1 & df2 \\
\hline $\begin{array}{r}\text { Number of } \\
\text { downloads (QRT) }\end{array}$ & $\begin{array}{c}3.963(* *) \\
.020\end{array}$ & 2 & 347 \\
\hline $\begin{array}{r}\text { Number of releases } \\
\text { (QRT) }\end{array}$ & $\begin{array}{l}.620 \\
(.539)\end{array}$ & 2 & 347 \\
\hline $\begin{aligned} * \mathrm{p} & <0.10 \\
* * \mathrm{p} & <0.05 \\
* * \mathrm{p} & <0.01\end{aligned}$ & & & \\
\hline
\end{tabular}

Results of Table 16 indicate that the Levene statistic is significant for number of downloads (at $\mathrm{p}<0.05$ ) and not significant for number of releases. Therefore, the variance for number of downloads is not equal across target user types. However, variance for number of releases is equal across target users types.

Since the number of downloads have unequal variance, the Welch and Brown-Forsythe robust $\mathrm{F}$ tests were used to test hypotheses $3 \mathrm{a}$ instead of the One-Way ANOVA (which 
requires equality of variance). As the number of releases has equal variances, One-Way ANOVA test was used to test Hypothesis $3 b$

Table 17 provides the results of using the Welch and Brown-Forsythe robust $F$ tests to examine Hypothesis $3 a$.

Table 17. Welch and Brown-Forsythe robust $F$ tests of equality of means of number of downloads across types of target users

$($ Sample size $=350)$

\begin{tabular}{|c|c|c|c|c|}
\hline & & Statistic & df1 & df2 \\
\hline \multirow{2}{*}{$\begin{array}{r}\text { Number of } \\
\text { downloads (QRT) }\end{array}$} & Welch & $\begin{array}{c}4.064(* * *) \\
.018\end{array}$ & 2 & 231.080 \\
\hline & Brown-Forsythe & $\begin{array}{c}3.672(* * *) \\
.026\end{array}$ & 2 & 338.723 \\
\hline $\begin{array}{ll}{ }^{*} \mathrm{p} & <0.10 \\
{ }^{*} \mathrm{p} & <0.05 \\
\mathrm{*} p & <0.01\end{array}$ & & & & \\
\hline
\end{tabular}

The null Hypothesis was that the average number of downloads is the same for all three target users types. The results in Table 17 show that the Welch and Brown-Forsythe statistics are significant at $\mathrm{p}<0.05$. Therefore, the null Hypothesis that the average number of downloads is the same for all target users types can be rejected.

Table 18 provides the multiple comparison results of the Tamhane T2 test used to examine Hypothesis 3a. The test was used to compare average number of downloads across the three target users types because it does not assume equal variances. 
Table 18. Multiple comparisons of average number of downloads across types of target users

$($ Sample size $=350)$

Number of downloads (QRT)

\begin{tabular}{|c|c|c|c|c|c|}
\hline \multirow{2}{*}{$\begin{array}{l}\text { (I) Target users } \\
\text { type }\end{array}$} & \multirow{2}{*}{ Mean } & \multirow{2}{*}{$\begin{array}{c}\text { (J) Target users } \\
\text { type }\end{array}$} & \multirow{2}{*}{$\begin{array}{c}\text { Mean } \\
\text { difference } \\
(\mathbf{I}-\mathrm{J})\end{array}$} & \multicolumn{2}{|c|}{$\begin{array}{c}90 \% \text { Confidence } \\
\text { interval }\end{array}$} \\
\hline & & & & $\begin{array}{l}\text { Lower } \\
\text { bound }\end{array}$ & $\begin{array}{l}\text { Upper } \\
\text { bound }\end{array}$ \\
\hline \multirow{2}{*}{ Developers } & \multirow{2}{*}{12.2315} & $\begin{array}{c}\text { System } \\
\text { administrators }\end{array}$ & $\begin{array}{l}2.4035\left(^{*}\right) \\
.071\end{array}$ & .1214 & 4.6855 \\
\hline & & End users & $\begin{array}{c}2.3861\left(^{* *}\right) \\
.030\end{array}$ & .2232 & 4.5490 \\
\hline \multirow{2}{*}{$\begin{array}{c}\text { System } \\
\text { administrators }\end{array}$} & \multirow{2}{*}{9.8280} & Developers & $\begin{array}{c}-2.4035\left(^{*}\right) \\
.071\end{array}$ & -4.6855 & -.1214 \\
\hline & & End users & $\begin{array}{c}-.0174 \\
(1.000)\end{array}$ & -2.1913 & 2.1566 \\
\hline \multirow{2}{*}{ End users } & \multirow{2}{*}{9.8454} & Developers & $\begin{array}{c}-2.3861(* *) \\
.030\end{array}$ & -4.5490 & -.2232 \\
\hline & & $\begin{array}{c}\text { System } \\
\text { administrators }\end{array}$ & $\begin{array}{c}.0174 \\
(1.000)\end{array}$ & -2.1566 & 2.1913 \\
\hline $\begin{aligned} * \mathrm{p} & <0.10 \\
* * \mathrm{p} & <0.05 \\
* * * \mathrm{p} & <0.01\end{aligned}$ & & & & & \\
\hline
\end{tabular}

Results of Table 18 indicate that the average number of downloads is greater if the target users of the OSS project are developers instead of system administrators and end users. The results are significant at $\mathrm{p}<0.05$. However, the difference between average number 
of downloads is not significant for system administrators or end users. These results also indicate support for Hypothesis $3 a$.

Table 19 provides the results of the One-Way ANOVA test for Hypothesis $3 b$.

Table 19. One-Way ANOVA test of equality of means of number of releases across types of target users

$($ Sample size $=350)$

\begin{tabular}{|c|c|c|c|c|c|}
\hline & & $\begin{array}{l}\text { Sum of } \\
\text { squares }\end{array}$ & df & $\begin{array}{l}\text { Mean } \\
\text { square }\end{array}$ & $\mathbf{F}$ \\
\hline \multirow{3}{*}{$\begin{array}{l}\text { Number of } \\
\text { releases (QRT) }\end{array}$} & $\begin{array}{l}\text { Between } \\
\text { groups }\end{array}$ & 9.853 & 2 & 4.927 & $\begin{array}{c}17.084(* * *) \\
.000\end{array}$ \\
\hline & Within groups & 100.071 & 347 & .288 & \\
\hline & Total & 109.924 & 349 & & \\
\hline $\begin{array}{rr}{ }^{*} \mathrm{p} & <0.10 \\
* * \mathrm{p} & <0.05 \\
*^{* *} \mathrm{p} & <0.01\end{array}$ & & & & & \\
\hline
\end{tabular}

The null Hypothesis was that the average number of releases is the same for all three target users types. The results in Table 19 indicate that the F statistic is significant at $\mathrm{p}<$ 0.01. Therefore, the null Hypothesis that the average number of releases is the same for all categories of target user types can be rejected. 
Table 20 provides the multiple comparison results of using the Bonferroni test to examine Hypothesis $3 \mathrm{~b}$. This test was used to compare the average number of releases across the target users types because it assumes equal variances.

The results shown in Table 20 indicate that the average number of releases is greater if the targeted users of the OSS software project are developers instead of system administrators and end users. The results are significant at $\mathrm{p}<0.01$. Moreover, the average number of releases is greater if the target users are system administrators instead of end users. The results are significant at $p<0.05$. These results also indicate support for Hypothesis $3 b$. 
Table 20. Multiple comparisons of average number of releases across types of target users

$($ Sample size $=350)$

Number of releases (QRT)

\begin{tabular}{|c|c|c|c|c|c|}
\hline \multirow{2}{*}{$\begin{array}{c}\text { (I) Target users } \\
\text { type }\end{array}$} & \multirow{2}{*}{ Mean } & \multirow{2}{*}{$\begin{array}{c}\text { (J) Target users } \\
\text { type }\end{array}$} & \multirow{2}{*}{$\begin{array}{c}\text { Mean } \\
\text { difference } \\
\text { (I-J) }\end{array}$} & \multicolumn{2}{|c|}{$\begin{array}{c}90 \% \text { Confidence } \\
\text { interval }\end{array}$} \\
\hline & & & & $\begin{array}{l}\text { Lower } \\
\text { bound }\end{array}$ & $\begin{array}{l}\text { Upper } \\
\text { bound }\end{array}$ \\
\hline \multirow{2}{*}{ Developers } & \multirow{2}{*}{2.3992} & $\begin{array}{c}\text { System } \\
\text { administrators }\end{array}$ & $\begin{array}{c}.2352(* * *) \\
.004\end{array}$ & .0791 & .3914 \\
\hline & & End users & $\begin{array}{c}.4047(* * *) \\
.000\end{array}$ & .2567 & .5527 \\
\hline \multirow{2}{*}{$\begin{array}{c}\text { System } \\
\text { administrators }\end{array}$} & \multirow{2}{*}{2.1639} & Developers & $\begin{array}{c}-.2352(* * *) \\
.004\end{array}$ & -.3914 & -.0791 \\
\hline & & End users & $\begin{array}{c}.1694(* *) \\
.046\end{array}$ & .0207 & .3182 \\
\hline \multirow{2}{*}{ End users } & \multirow{2}{*}{1.9945} & Developers & $\begin{array}{c}-.4047(* * *) \\
.000\end{array}$ & -.5527 & -.2567 \\
\hline & & $\begin{array}{c}\text { System } \\
\text { administrators }\end{array}$ & $\begin{array}{c}-.1694(* *) \\
.046\end{array}$ & -.3182 & -.0207 \\
\hline $\begin{aligned}{ }^{*} \mathrm{p} & <0.10 \\
{ }^{* *} \mathrm{p} & <0.05 \\
* * * \mathrm{p} & <0.01\end{aligned}$ & & & & & \\
\hline
\end{tabular}


5.7 Hypothesis 4. Using a commonly used programming language is positively associated with the success of OSS project

Hypotheses $4 \mathrm{a}$ and $4 \mathrm{~b}$ posit that the use of a commonly used programming language is positively associated with the number of downloads and the number of releases of the OSS project respectively.

The results shown in Table 9 failed to support Hypotheses $4 \mathrm{a}$ and $4 \mathrm{~b}$. To test hypotheses $4 \mathrm{a}$ and $4 \mathrm{~b}$, the researcher first checked whether or not the variance of the number of downloads and the number of releases is homogeneous across the two programming language types. Table 21 provides the results of using the Levene test of homogeneity of variances.

Table 21. Levene test for homogeneity of variances for number of downloads and number of releases across programming language types

$($ Sample size $=350)$

\begin{tabular}{|c|c|c|c|}
\hline & Levene statistic & df1 & df2 \\
\hline $\begin{array}{r}\text { Number of } \\
\text { downloads (QRT) }\end{array}$ & $\begin{array}{l}.607 \\
(.437)\end{array}$ & 1 & 348 \\
\hline $\begin{array}{r}\text { Number of releases } \\
\text { (QRT) }\end{array}$ & $\begin{array}{l}3.764 \\
.053(*)\end{array}$ & 1 & 348 \\
\hline $\begin{aligned} * \mathrm{p} & <0.10 \\
* * \mathrm{p} & <0.05 \\
* * \mathrm{p} & <0.01\end{aligned}$ & & & \\
\hline
\end{tabular}

Results of Table 21 indicate that the Levene statistic is not significant for number of downloads and is significant for number of releases (at $\mathrm{p}<0.05$ ). Therefore, the variance 
for number of downloads is equal across the two programming language types. However, variance for number of releases is not equal across programming language type.

Since the number of downloads have equal variance, the One-Way ANOVA test was used to test hypotheses $4 \mathrm{a}$. As the number of releases have unequal variance, Welch and Brown-Forsythe robust $F$ tests were used to test Hypothesis $4 b$.

Table 22 provides the results of using the One-way ANOVA test to examine Hypothesis 4a.

Table 22. One-Way ANOVA test of equality of means of number of downloads across programming language types

$($ Sample size $=350)$

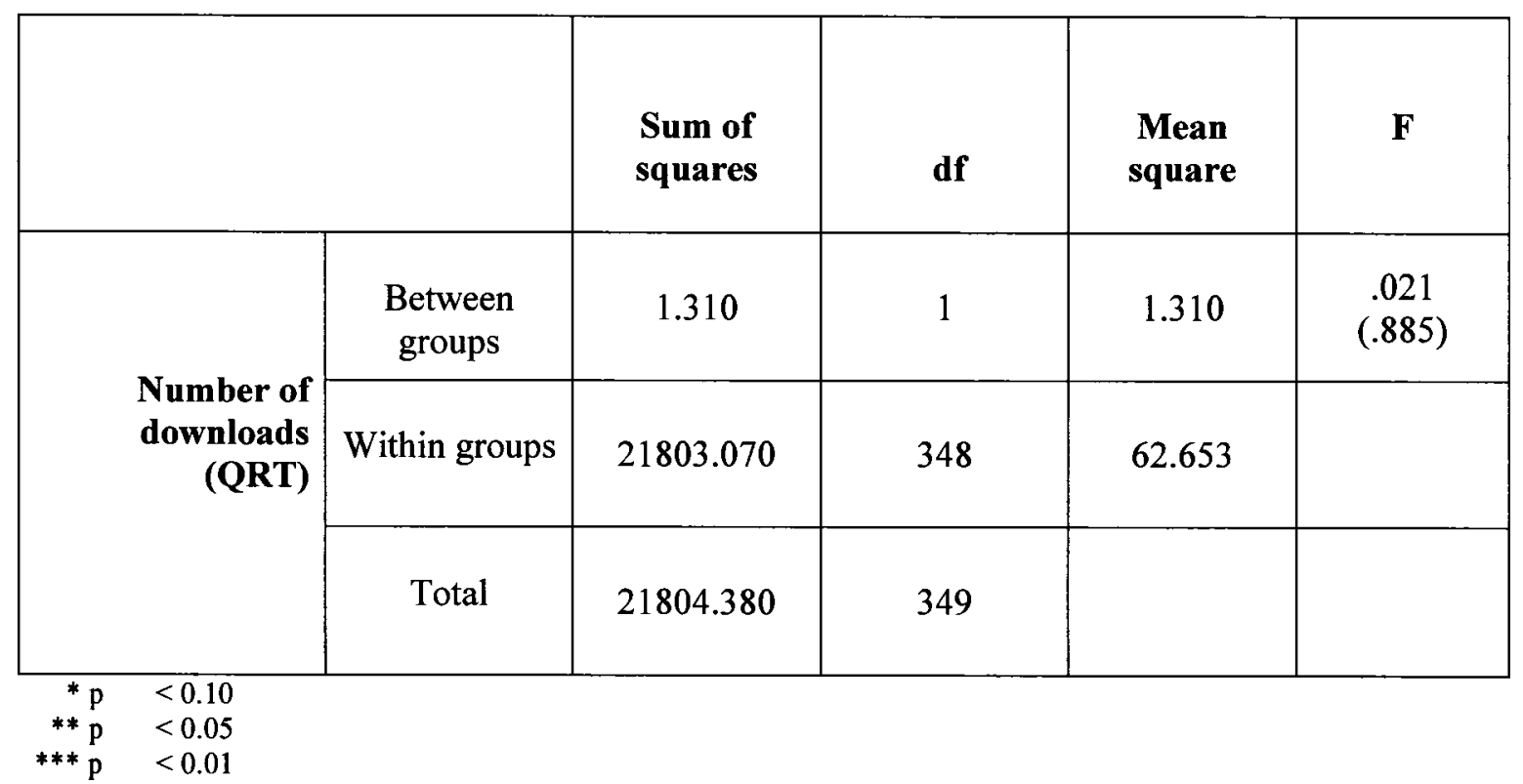

The null Hypothesis was that the average number of downloads is the same for the two types of programming languages. Results in Table 22 indicate that the F statistic is not 
significant. Therefore, the null Hypothesis that the average number of downloads is the same for all types of programming language cannot be rejected. Thus, Hypothesis $4 \mathrm{a}$ is not supported.

Table 23 provides the results of the Welch and Brown-Forsyth robust $F$ tests used to examine Hypothesis $4 b$.

Table 23. Welch and Brown-Forsyth robust $F$ tests of equality of means of number of releases across programming language types

$($ Sample size $=350)$

\begin{tabular}{|c|c|c|c|c|}
\hline & & Statistic & df1 & df2 \\
\hline \multirow{2}{*}{$\begin{array}{r}\text { Number of } \\
\text { downloads (QRT) }\end{array}$} & Welch & $\begin{array}{l}1.472 \\
.226\end{array}$ & 1 & 210.634 \\
\hline & Brown-Forsythe & $\begin{array}{l}1.472 \\
.226\end{array}$ & 1 & 210.634 \\
\hline $\begin{array}{ll}{ }^{*} \mathrm{p} & <0.10 \\
{ }^{*} \mathrm{p} & <0.05 \\
{ }^{*} \mathrm{p} & <0.01\end{array}$ & & & & \\
\hline
\end{tabular}

The null Hypothesis was that the average number of releases is the same for all types of programming language. The results shown in Table 23 indicate that the Welch and Brown-Forsyth statistics are not significant. Therefore, the null Hypothesis that the average number of releases is the same for all types of programming language cannot be rejected. Thus, Hypothesis $4 \mathrm{~b}$ is not supported. 
5.8 Hypothesis 5. Development of application development and deployment tools is positively associated with the success of OSS projects

Hypotheses $5 \mathrm{a}$ and $5 \mathrm{~b}$ posit that the development of application development and deployment tools is positively associated with the number of downloads and number of releases of OSS project respectively.

To test hypotheses $5 \mathrm{a}$ and $5 \mathrm{~b}$, the researcher first checked whether or not the variance of number of downloads and number of releases is homogeneous across the types of software. Table 24 provides the results of using the Levene test of homogeneity of variances.

Table 24. Levene test for homogeneity of variances for number of downloads and number of releases across types of software

$($ Sample size $=350)$

\begin{tabular}{|r|c|c|c|}
\hline & Levene statistic & df1 & df2 \\
\hline $\begin{array}{r}\text { Number of } \\
\text { downloads (QRT) }\end{array}$ & $\begin{array}{c}1.776 \\
(.171)\end{array}$ & 2 & 347 \\
\hline $\begin{array}{r}\text { Number of releases } \\
\text { (QRT) }\end{array}$ & $\begin{array}{c}.827 \\
(.438)\end{array}$ & 2 & 347 \\
$\begin{aligned} * \mathrm{p} \quad<0.10 \\
* * \mathrm{p} \quad<0.05 \\
* * * \mathrm{p}<0.01\end{aligned}$
\end{tabular}

Results shown in Table 24 indicate that the Levene statistic is not significant both for number of downloads and number of releases. Therefore, the variances for number of downloads and number of releases are equal across the types of software. 
Since number of downloads and number of releases for types of software have equal variance, the One-Way ANOVA test was used to test hypotheses 5a and 5b.

Table 25 provides the results of using the One-Way ANOVA test to examine Hypothesis

$5 a$.

Table 25. One-Way ANOVA test of equality of means of number of downloads across types of software

$($ Sample size $=350)$

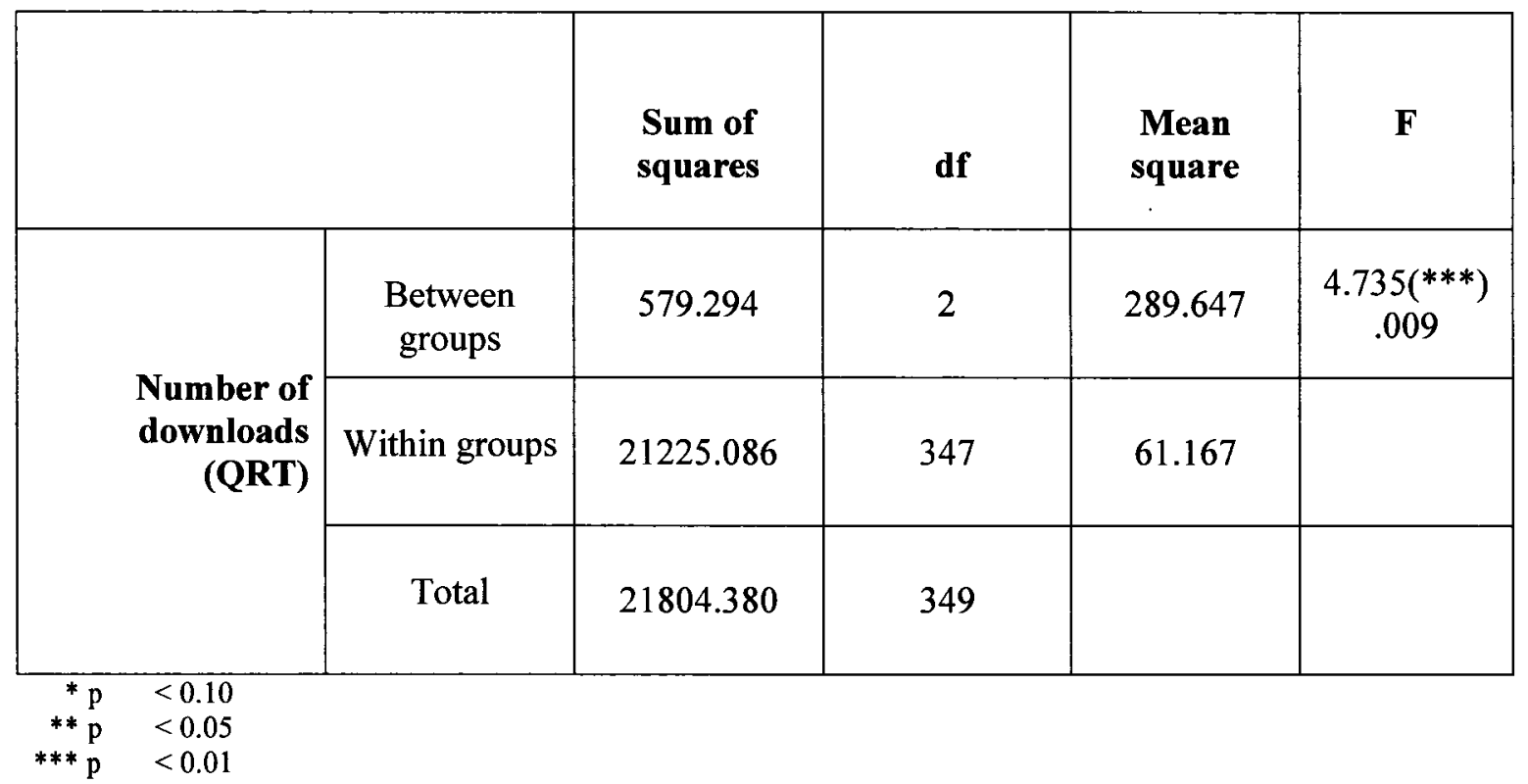

The null Hypothesis was that the average number of downloads is the same for all types of software. The results shown in Table 25 indicate that the F statistic is significant at $p<$ 0.01. Therefore, the null Hypothesis that the average number of downloads is the same for all types of software can be rejected. 
Table 26 provides the multiple comparison results of the Bonferroni test for Hypothesis

5a. The test was used to compare the average number of downloads across the types of software because it assumes equal variances.

The results shown in Table 26 indicate that the average number of downloads is greater if the application development and deployment tools are developed instead of system infrastructure software and application software. The results are significant at $\mathrm{p}<0.01$. However, the difference between average number of downloads is not significant when the type of OSS software is either system infrastructure software or application software. These results indicate support for Hypothesis $5 \mathrm{a}$. 
Table 26. Multiple comparisons of average number of downloads across types of software

$($ Sample size $=350)$

Number of downloads (QRT)

\begin{tabular}{|c|c|c|c|c|c|}
\hline \multirow[b]{2}{*}{$\begin{array}{l}\text { (I) Type of } \\
\text { software }\end{array}$} & \multirow[b]{2}{*}{ Mean } & \multirow[b]{2}{*}{$\begin{array}{l}\text { (J) Type of } \\
\text { software }\end{array}$} & \multirow[b]{2}{*}{$\begin{array}{c}\text { Mean } \\
\text { difference } \\
\text { (I-J) }\end{array}$} & \multicolumn{2}{|c|}{$\begin{array}{c}90 \% \text { Confidence } \\
\text { interval }\end{array}$} \\
\hline & & & & $\begin{array}{l}\text { Lower } \\
\text { bound }\end{array}$ & $\begin{array}{l}\text { Upper } \\
\text { bound }\end{array}$ \\
\hline \multirow{2}{*}{$\begin{array}{l}\text { Application } \\
\text { software }\end{array}$} & \multirow[t]{2}{*}{9.3579} & $\begin{array}{c}\text { Application } \\
\text { development and } \\
\text { deployment } \\
\text { tools } \\
\end{array}$ & $\begin{array}{c}- \\
3.0662(* * *) \\
.008\end{array}$ & -5.2402 & -.8922 \\
\hline & & $\begin{array}{c}\text { System } \\
\text { infrastructure } \\
\text { software }\end{array}$ & $\begin{array}{l}-.8448 \\
1.000\end{array}$ & -3.0029 & 1.3134 \\
\hline \multirow{2}{*}{$\begin{array}{c}\text { Application } \\
\text { development and } \\
\text { deployment tools }\end{array}$} & \multirow{2}{*}{12.4242} & $\begin{array}{l}\text { Application } \\
\text { software }\end{array}$ & $\begin{array}{c}3.0662(* * *) \\
.008\end{array}$ & .8922 & 5.2402 \\
\hline & & $\begin{array}{c}\text { System } \\
\text { infrastructure } \\
\text { software }\end{array}$ & $\begin{array}{c}2.2215 \\
.106\end{array}$ & -.0268 & 4.4697 \\
\hline \multirow{2}{*}{$\begin{array}{c}\text { System } \\
\text { infrastructure } \\
\text { software }\end{array}$} & \multirow{2}{*}{10.2027} & $\begin{array}{l}\text { Application } \\
\text { software }\end{array}$ & $\begin{array}{l}.8448 \\
1.000\end{array}$ & -1.3134 & 3.0029 \\
\hline & & $\begin{array}{c}\text { Application } \\
\text { development and } \\
\text { deployment } \\
\text { tools }\end{array}$ & $\begin{array}{c}-2.2215 \\
.106\end{array}$ & -4.4697 & .0268 \\
\hline $\begin{aligned} *{ }_{*} \mathrm{p} & <0.10 \\
* * \mathrm{p} & <0.05 \\
* * * \mathrm{p} & <0.01\end{aligned}$ & & & & & \\
\hline
\end{tabular}


Table 27 provides the results of using the One-Way ANOVA test to examine Hypothesis $5 b$.

Table 27. One-Way ANOVA test of equality of means of number of releases across types of software

$($ Sample size $=350)$

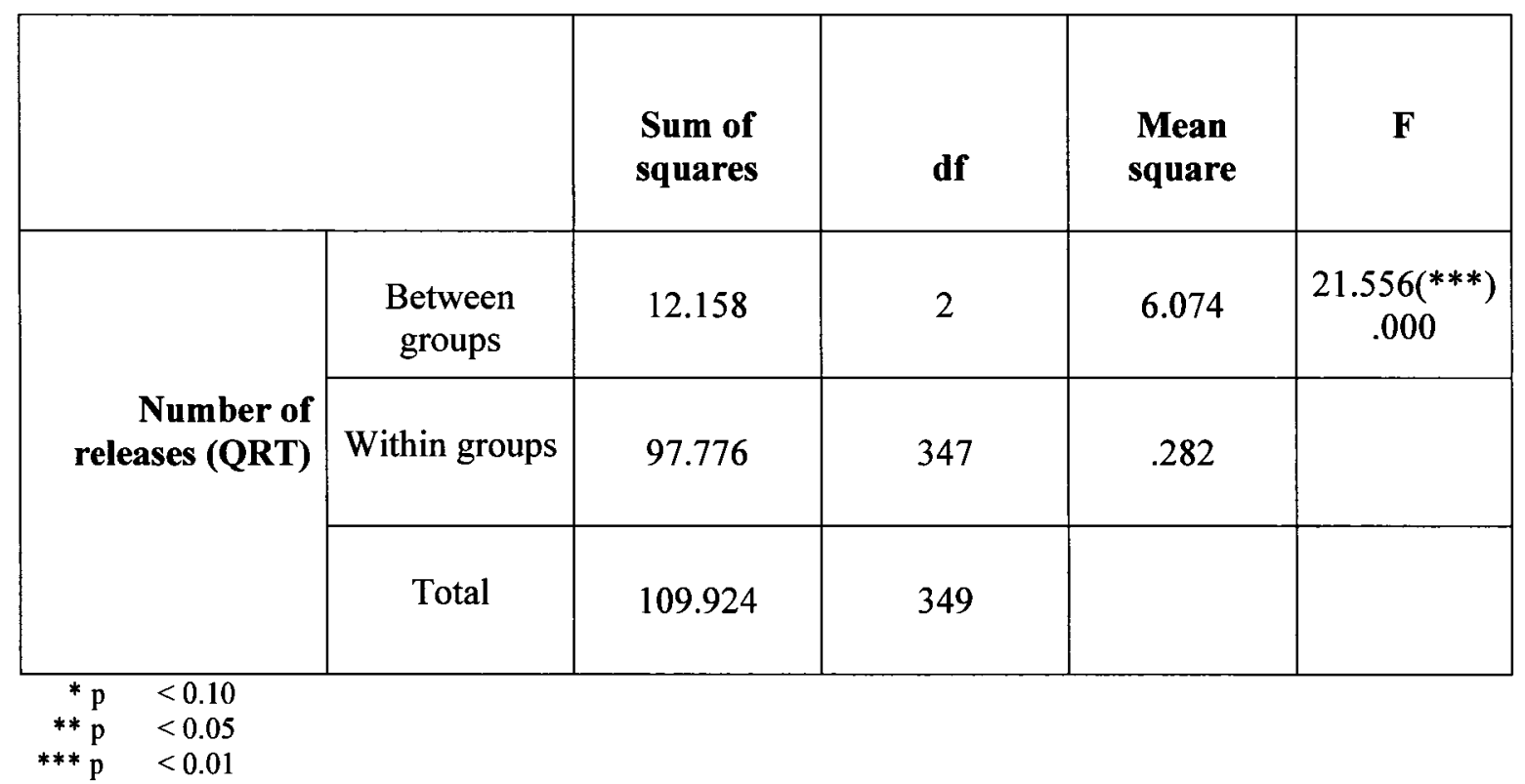

The null Hypothesis was that the average number of releases is the same for all types of software. Results shown in Table 27 indicate that the F statistic is significant at $\mathrm{p}<0.01$. Therefore, the null Hypothesis that the average number of releases is the same for all types of software can be rejected.

Table 28 provides multiple comparison results of Bonferroni test for Hypothesis $5 \mathrm{~b}$. This test was used to compare average number of releases across the types of software because it assumes equal variances. 
The results shown in Table 28 indicate that the average number of releases is greater if the application development and deployment tools are developed instead of system infrastructure software and application software. The results are significant at $\mathrm{p}<0.01$. Moreover, the average number of releases is greater if the system infrastructure software is developed instead of application software. The results are significant at $p<0.05$. These results indicate support for Hypothesis $5 b$. 
Table 28. Multiple comparisons of average number of releases across software types

$($ Sample size $=350)$

Number of releases $(\mathrm{QRT})$

\begin{tabular}{|c|c|c|c|c|c|}
\hline \multirow[b]{2}{*}{$\begin{array}{l}\text { (I) Type of } \\
\text { software }\end{array}$} & \multirow[b]{2}{*}{ Mean } & \multirow[b]{2}{*}{$\begin{array}{l}\text { (J) Type of } \\
\text { software }\end{array}$} & \multirow[b]{2}{*}{$\begin{array}{c}\text { Mean } \\
\text { difference } \\
(I-J)\end{array}$} & \multicolumn{2}{|c|}{$\begin{array}{c}90 \% \text { Confidence } \\
\text { interval }\end{array}$} \\
\hline & & & & $\begin{array}{l}\text { Lower } \\
\text { bound }\end{array}$ & $\begin{array}{l}\text { Upper } \\
\text { bound }\end{array}$ \\
\hline \multirow{2}{*}{$\begin{array}{l}\text { Application } \\
\text { software }\end{array}$} & \multirow[t]{2}{*}{1.9711} & \begin{tabular}{|c|} 
Application \\
development and \\
deployment \\
tools \\
\end{tabular} & $\begin{array}{c}-.4529(* * *) \\
.000\end{array}$ & -.6005 & -.3054 \\
\hline & & $\begin{array}{c}\text { System } \\
\text { infrastructure } \\
\text { software }\end{array}$ & $\begin{array}{c}-.1881\left(^{* *}\right) \\
.019\end{array}$ & -.3346 & -.0416 \\
\hline \multirow{2}{*}{$\begin{array}{c}\text { Application } \\
\text { development and } \\
\text { deployment tools }\end{array}$} & \multirow{2}{*}{2.4240} & $\begin{array}{l}\text { Application } \\
\text { software }\end{array}$ & $\begin{array}{c}.4529(* * *) \\
.000\end{array}$ & .3054 & .6005 \\
\hline & & $\begin{array}{c}\text { System } \\
\text { infrastructure } \\
\text { software }\end{array}$ & $\begin{array}{c}.2648(* * *) \\
.001\end{array}$ & .1122 & .4174 \\
\hline \multirow{2}{*}{$\begin{array}{c}\text { System } \\
\text { infrastructure } \\
\text { software }\end{array}$} & \multirow{2}{*}{2.1592} & $\begin{array}{l}\text { Application } \\
\text { software }\end{array}$ & $\begin{array}{c}.1881(* *) \\
.019\end{array}$ & .0416 & .3346 \\
\hline & & $\begin{array}{c}\text { Application } \\
\text { development and } \\
\text { deployment } \\
\text { tools } \\
\end{array}$ & $\begin{array}{c}-.2648(* * *) \\
.001\end{array}$ & -.4174 & -.1122 \\
\hline $\begin{aligned} * \mathrm{p} & <0.10 \\
* * \mathrm{p} & <0.05 \\
* * * \mathrm{p} & <0.01\end{aligned}$ & & & & & \\
\hline
\end{tabular}


5.9 Hypothesis 6. Use of non-restrictive OSS license is positively associated with the success of OSS projects

Hypotheses $6 \mathrm{a}$ and $6 \mathrm{~b}$ posit that use of non-restrictive OSS license is positively associated with the number of downloads and number of releases of OSS project respectively.

To test hypotheses $6 a$ and $6 \mathrm{~b}$, the researcher first checked whether or not the variance of number of downloads and number of releases is homogeneous across the types of license. Table 29 provides the results of using the Levene test of homogeneity of variances to examine homogeneity of variances for number of downloads and number of releases across license types.

Table 29. Levene test for homogeneity of variances for number of downloads and number of releases across types of license

$($ Sample size $=350)$

\begin{tabular}{|c|c|c|c|}
\hline & Levene statistic & df1 & df2 \\
\hline $\begin{array}{r}\text { Number of } \\
\text { downloads }(Q R T)\end{array}$ & $\begin{array}{c}4.582(* *) \\
.011\end{array}$ & 2 & 347 \\
\hline $\begin{array}{r}\text { Number of releases } \\
\text { (QRT) }\end{array}$ & $\begin{array}{l}1.505 \\
(.223)\end{array}$ & 2 & 347 \\
\hline $\begin{aligned} * \mathrm{p} & <0.10 \\
* * \mathrm{p} & <0.05 \\
* * \mathrm{p} & <0.01\end{aligned}$ & & & \\
\hline
\end{tabular}


The results shown in Table 21 indicate that the Levene statistic is significant for number of downloads (at $\mathrm{p}<0.05$ ) and is not significant for number of releases. Therefore, the variance for number of downloads is not equal across the software types. However, variance for number of releases is equal across software types.

Since the number of downloads have unequal variance, the Welch and Brown-Forsyth robust $\mathrm{F}$ tests were used to test hypotheses $3 \mathrm{a}$ instead of the One-Way ANOVA (which requires equality of variance). As the number of releases have equal variance, One-Way ANOVA test was used to test Hypothesis $3 b$.

Table 30 provides the results of using the Welch and Brown-Forsyth robust $F$ tests to examine Hypothesis 6a.

Table 30. Welch and Brown-Forsythe robust $F$ tests of equality of means of number of downloads across types of license

$($ Sample size $=350)$

\begin{tabular}{|c|c|c|c|c|}
\hline & & Statistic & dfi & df2 \\
\hline \multirow{2}{*}{$\begin{array}{r}\text { Number of } \\
\text { downloads (QRT) }\end{array}$} & Welch & $\begin{array}{c}3.214\left(^{* *}\right) \\
.044\end{array}$ & 2 & 119.708 \\
\hline & Brown-Forsythe & $\begin{array}{c}3.516\left(^{* *}\right) \\
.032\end{array}$ & 2 & 202.002 \\
\hline $\begin{array}{ll}{ }^{*} \mathrm{p} & <0.10 \\
*_{\mathrm{p}} & <0.05 \\
*_{\mathrm{p}} & <0.01\end{array}$ & & & & \\
\hline
\end{tabular}


The null Hypothesis was that the average number of downloads is the same for all types of license. The results shown in Table 30 indicate that the Welch and Brown-Forsyth statistic are significant at $\mathrm{p}<0.05$. Therefore, the null Hypothesis that the average number of downloads is the same for all types of license can be rejected.

Table 31 provides the multiple comparison results for the Tamhane T2 test used to examine Hypothesis 6a. This test was used to compare average number of downloads across the types of license because it does not assume equal variances. 
Table 31. Multiple comparisons of average number of downloads across license types

$($ Sample size $=350)$

Number of downloads (QRT)

\begin{tabular}{|c|c|c|c|c|c|}
\hline \multirow[b]{2}{*}{$\begin{array}{l}\text { (I) Type of } \\
\text { license }\end{array}$} & \multirow[b]{2}{*}{ Mean } & \multirow[b]{2}{*}{$\begin{array}{l}\text { (J) Type of } \\
\text { license }\end{array}$} & \multirow[b]{2}{*}{$\begin{array}{c}\text { Mean } \\
\text { difference } \\
\text { (I-J) }\end{array}$} & \multicolumn{2}{|c|}{$\begin{array}{l}90 \% \text { Confidence } \\
\text { interval }\end{array}$} \\
\hline & & & & $\begin{array}{l}\text { Lower } \\
\text { bound }\end{array}$ & $\begin{array}{l}\text { Upper } \\
\text { bound }\end{array}$ \\
\hline \multirow{2}{*}{ Very restrictive } & \multirow{2}{*}{9.5543} & $\begin{array}{l}\text { Moderately } \\
\text { restrictive }\end{array}$ & $\begin{array}{l}-1.85147 \\
.295\end{array}$ & -4.0847 & .5815 \\
\hline & & Non-restrictive & $\begin{array}{c}-2.55240\left(^{*}\right) \\
.073\end{array}$ & -4.7646 & -.1402 \\
\hline \multirow{2}{*}{$\begin{array}{l}\text { Moderately } \\
\text { restrictive }\end{array}$} & \multirow{2}{*}{11.4058} & Very restrictive & $\begin{array}{l}1.85147 \\
.295\end{array}$ & -.5818 & 4.0847 \\
\hline & & Non-restrictive & $\begin{array}{c}-.70093 \\
.939\end{array}$ & -3.642 & 2.2023 \\
\hline \multirow{2}{*}{ Non-restrictive } & \multirow{2}{*}{12.1067} & Very restrictive & $\begin{array}{l}2.55240\left(^{*}\right) \\
.073\end{array}$ & .1402 & 4.7646 \\
\hline & & $\begin{array}{l}\text { Moderately } \\
\text { restrictive }\end{array}$ & $\begin{array}{c}.70093 \\
.939\end{array}$ & -2.2023 & 3.6042 \\
\hline $\begin{aligned} * \mathrm{p} & <0.10 \\
* * \mathrm{p} & <0.05 \\
* * * \mathrm{p} & <0.01\end{aligned}$ & & & & & \\
\hline
\end{tabular}

The results shown in Table 31 indicate that the average number of releases is greater if a non-restrictive OSS license is used instead of a very restrictive OSS license. The results are significant at $p<0.1$. These results indicate support for Hypothesis $6 \mathrm{a}$. 
Table 32 provides the results of using the One-way ANOVA test to examine Hypothesis

$6 b$.

Table 32. One-Way ANOVA test of equality of means of number of releases across types of license

$($ Sample size $=350)$

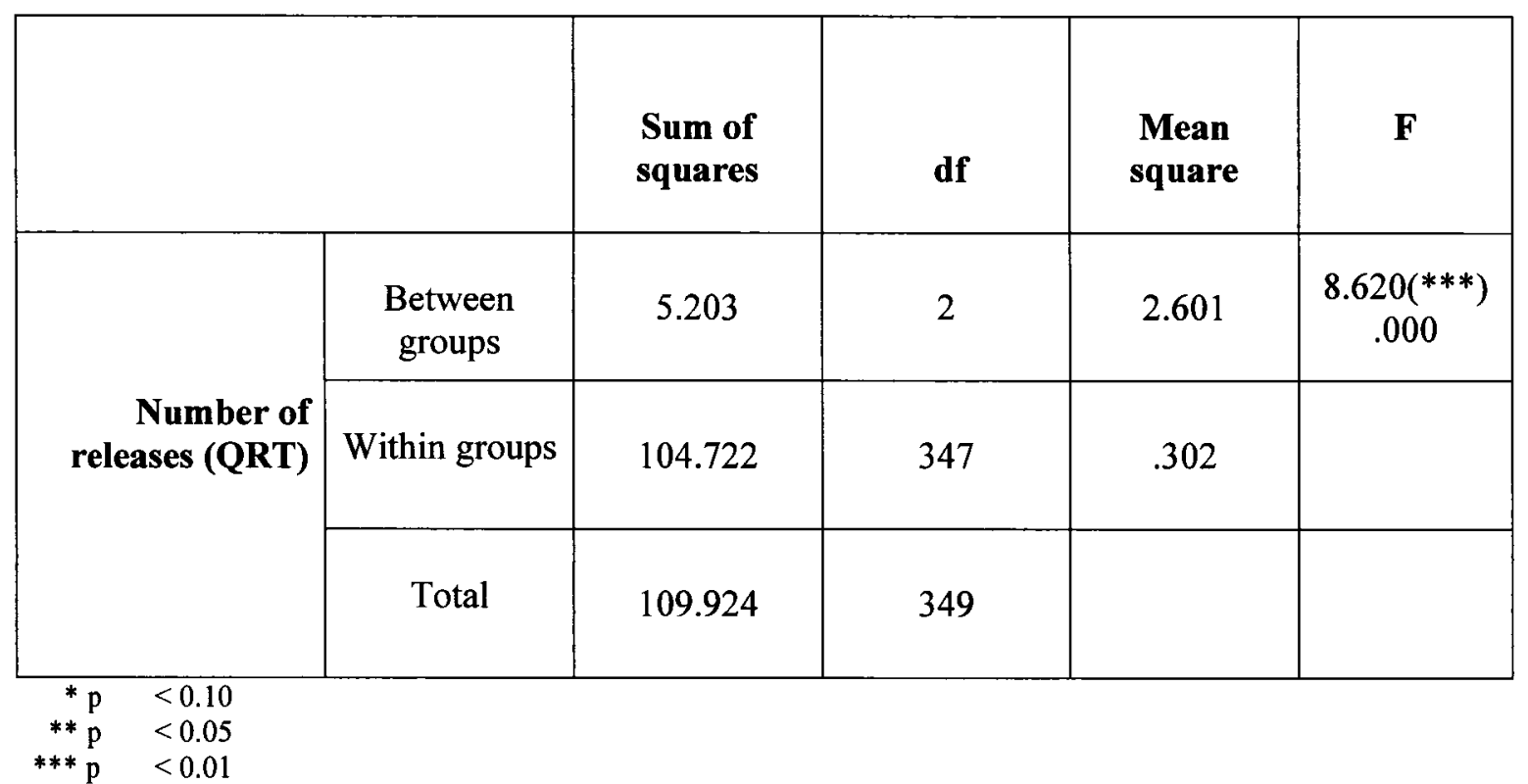

The null Hypothesis was that the average number of releases is the same for all types of license. Results in Table 32 indicate that the F statistic is significant at $p<0.01$.

Therefore, the null Hypothesis that the average number of releases is the same for all types of license can be rejected.

Table 33 provides the multiple comparison results of the Bonferroni test for Hypothesis $6 \mathrm{~b}$. This test was used to compare the average number of releases across the types of license because it assumes equal variances. 
Table 33. Multiple comparisons of average number of releases across license types

$($ Sample size $=350)$

Number of releases (QRT)

\begin{tabular}{|c|c|c|c|c|c|}
\hline \multirow{2}{*}{$\begin{array}{l}\text { (I) Type of } \\
\text { license }\end{array}$} & \multirow{2}{*}{ Mean } & \multirow{2}{*}{$\begin{array}{l}(J) \text { Type of } \\
\text { license }\end{array}$} & \multirow[b]{2}{*}{$\begin{array}{c}\text { Mean } \\
\text { difference } \\
\text { (I-J) }\end{array}$} & \multicolumn{2}{|c|}{$\begin{array}{c}90 \% \text { Confidence } \\
\text { interval }\end{array}$} \\
\hline & & & & $\begin{array}{l}\text { Lower } \\
\text { bound }\end{array}$ & $\begin{array}{l}\text { Upper } \\
\text { bound }\end{array}$ \\
\hline \multirow{2}{*}{ Very restrictive } & \multirow{2}{*}{2.0743} & $\begin{array}{l}\text { Moderately } \\
\text { restrictive }\end{array}$ & $\begin{array}{c}-.15010 \\
.277\end{array}$ & -.3400 & .0398 \\
\hline & & Non-restrictive & $\begin{array}{c}-.27541(* * *) \\
.000\end{array}$ & -.4192 & -.1316 \\
\hline \multirow{2}{*}{$\begin{array}{l}\text { Moderately } \\
\text { restrictive }\end{array}$} & \multirow{2}{*}{2.2244} & Very restrictive & $\begin{array}{c}.15010 \\
.277\end{array}$ & -.0398 & .3400 \\
\hline & & Non-restrictive & $\begin{array}{l}-.12531 \\
.596\end{array}$ & -.3332 & .0826 \\
\hline \multirow{2}{*}{ Non-restrictive } & \multirow{2}{*}{2.3497} & Very restrictive & $\begin{array}{c}.27541(* * *) \\
.000\end{array}$ & .1316 & .4192 \\
\hline & & $\begin{array}{l}\text { Moderately } \\
\text { restrictive }\end{array}$ & $\begin{array}{l}.12531 \\
.596\end{array}$ & -.0826 & .3332 \\
\hline $\begin{array}{rr}* \mathrm{p} & <0.10 \\
* * \mathrm{p} & <0.05 \\
* * * \mathrm{p} & <0.01\end{array}$ & & & & & \\
\hline
\end{tabular}

The results shown in Table 33 indicate that the average number of releases is greater if a non-restrictive OSS license is used instead of a very restrictive OSS license. The results are significant at $\mathrm{p}<0.01$. These results indicate support for Hypothesis $6 \mathrm{~b}$. 


\subsection{Summary of the results organized by hypothesis}

Table 34 provides a summary of the results of testing the six hypotheses.

Table 34. Summary of test results organized by hypothesis

(Sample size $\mathrm{N}=350$ )

\begin{tabular}{|c|c|c|}
\hline Hypothesis & $\begin{array}{l}\text { Decision } \\
\text { based on test } \\
\text { results }\end{array}$ & Rationale \\
\hline $\begin{array}{l}\text { Hypothesis 1a. Number of } \\
\text { developers is positively associated } \\
\text { with the number of downloads of } \\
\text { OSS projects. }\end{array}$ & Supported & $\begin{array}{l}\text { In multivariate GLM the effect of } \\
\text { number of developers on number } \\
\text { of downloads is significant } \\
\text { because Pillai's trace, Wilk's } \\
\text { lambda, Hotelling's trace, Roy's } \\
\text { largest root and F statistics for } \\
\text { these are significant at } p<0.05 \\
\text { with observed power equal to } \\
0.734 \text { and co-efficient equal to } \\
0.019 \text {. } \\
\text { Spearman correlation coefficient } \\
\text { between number of developers and } \\
\text { number of downloads of OSS } \\
\text { development project was positive } \\
\text { and significant at } p<0.01 \text {. }\end{array}$ \\
\hline $\begin{array}{l}\text { Hypothesis } 1 \text { b. Number of } \\
\text { developers is positively associated }\end{array}$ & Supported & $\begin{array}{l}\text { In multivariate GLM the effect of } \\
\text { number of developers on number }\end{array}$ \\
\hline
\end{tabular}




\begin{tabular}{|c|c|c|}
\hline $\begin{array}{l}\text { with the number of releases of OSS } \\
\text { projects. }\end{array}$ & & $\begin{array}{l}\text { of releases is significant because } \\
\text { Pillai's trace, Wilk's lambda, } \\
\text { Hotelling's trace, Roy's largest } \\
\text { root and F statistics for these are } \\
\text { significant at } \mathrm{p}<0.05 \text { with } \\
\text { observed power equal to } 0.734 \text { and } \\
\text { coefficient equal to } 0.19 \text {. } \\
\text { Spearman correlation coefficient } \\
\text { between number of developers and } \\
\text { number of releases of OSS } \\
\text { development project was positive } \\
\text { and significant at } \mathrm{p}<0.01 \text {. }\end{array}$ \\
\hline $\begin{array}{l}\text { Hypothesis 2a. Experience of } \\
\text { developers is positively associated } \\
\text { with the number of downloads of } \\
\text { OSS projects. }\end{array}$ & Supported & $\begin{array}{l}\text { In multivariate GLM the effect of } \\
\text { experience of developers on } \\
\text { number of downloads is } \\
\text { significant because Pillai's trace, } \\
\text { Wilk's lambda, Hotelling's trace, } \\
\text { Roy's largest root and F statistics } \\
\text { for these are significant at p }<0.05 \\
\text { with observed power equal to } \\
0.860 \text { and coefficient equal to } \\
0.021 \text {. }\end{array}$ \\
\hline & & Spearman correlation coefficient \\
\hline
\end{tabular}




\begin{tabular}{|c|c|c|}
\hline & & $\begin{array}{l}\text { between experience of developers } \\
\text { and number of downloads of OSS } \\
\text { development project was positive } \\
\text { and significant at } \mathrm{p}<0.01 \text {. }\end{array}$ \\
\hline $\begin{array}{l}\text { Hypothesis } \mathbf{2 b} \text {. Experience of } \\
\text { developers is positively associated } \\
\text { with the number of releases of OSS } \\
\text { projects. }\end{array}$ & Supported & $\begin{array}{l}\text { In multivariate GLM the effect of } \\
\text { experience of developers on } \\
\text { number of releases is significant } \\
\text { because Pillai's trace, Wilk's } \\
\text { lambda, Hotelling's trace, Roy's } \\
\text { largest root and F statistics for } \\
\text { these are significant at p < } 0.05 \\
\text { with observed power equal to } \\
0.860 \text { and coefficient equal to } \\
0.021 \text {. } \\
\text { Spearman correlation coefficient } \\
\text { between experience of developers } \\
\text { and number of releases of OSS } \\
\text { development project was positive } \\
\text { and significant at } p<0.01 \text {. }\end{array}$ \\
\hline $\begin{array}{l}\text { Hypothesis 3a. Targeting } \\
\text { developers as users is positively } \\
\text { associated with the number of } \\
\text { downloads of OSS projects. }\end{array}$ & Supported & $\begin{array}{l}\text { In multivariate GLM the effect of } \\
\text { target users type on number of } \\
\text { downloads is significant because }\end{array}$ \\
\hline
\end{tabular}




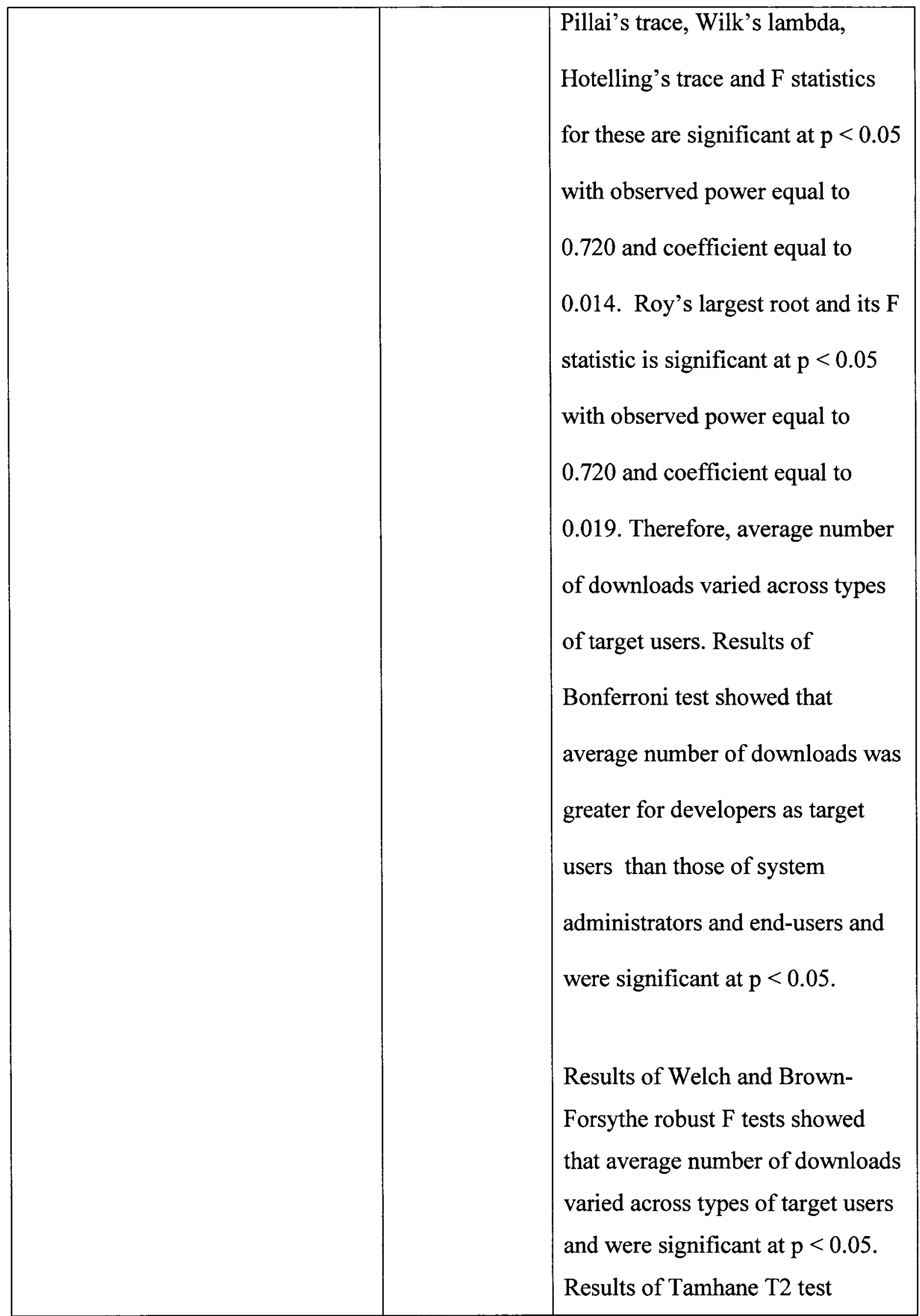




\begin{tabular}{|c|c|c|}
\hline & & $\begin{array}{l}\text { showed that average number of } \\
\text { downloads was greater for } \\
\text { developers as target users than } \\
\text { those of system administrators and } \\
\text { end-users and were significant at p } \\
<0.05 \text {. }\end{array}$ \\
\hline $\begin{array}{l}\text { Hypothesis 3b. Targeting } \\
\text { developers as users is positively } \\
\text { associated with the number of } \\
\text { releases of OSS projects. }\end{array}$ & Supported & $\begin{array}{l}\text { In multivariate GLM the effect of } \\
\text { target users type on number of } \\
\text { releases is significant because } \\
\text { Pillai's trace, Wilk's lambda, } \\
\text { Hotelling's trace and F statistics } \\
\text { for these are significant at p }<0.05 \\
\text { with observed power equal to } \\
0.720 \text { and coefficient equal to } \\
0.014 \text {. Roy's largest root and its F } \\
\text { statistic is significant at p < } 0.05 \\
\text { with observed power equal to } \\
0.720 \text { and coefficient equal to } \\
0.019 \text {. Therefore, average number } \\
\text { of releases varied across types of } \\
\text { target users. Results of Bonferroni } \\
\text { of releases was greater for }\end{array}$ \\
\hline
\end{tabular}




\begin{tabular}{|c|c|c|}
\hline & & $\begin{array}{l}\text { developers as target users than } \\
\text { those of system administrators and } \\
\text { end-users and were significant at p } \\
<0.01 \text {. } \\
\text { Results of One-Way ANOVA test } \\
\text { showed that average number of } \\
\text { releases varied across types of } \\
\text { target users and were significant at } \\
\text { p }<0.01 \text {. Results of Bonferroni } \\
\text { test showed that average number } \\
\text { of releases was greater for } \\
\text { developers as target users than } \\
\text { those of system administrators and } \\
\text { end-users and were significant at } p \\
<0.01\end{array}$ \\
\hline $\begin{array}{l}\text { Hypothesis 4a. Using a commonly } \\
\text { used programming language is } \\
\text { positively associated with the } \\
\text { number of downloads of OSS } \\
\text { projects. }\end{array}$ & Not supported & $\begin{array}{l}\text { In multivariate GLM the effect of } \\
\text { programming language type on } \\
\text { number of downloads is not } \\
\text { significant because Pillai's trace, } \\
\text { Wilk's lambda, Hotelling's trace, } \\
\text { Roy's largest root and F statistics } \\
\text { for these are not significant at } p< \\
0.1 \text {. Therefore, average number of }\end{array}$ \\
\hline
\end{tabular}




\begin{tabular}{|c|c|c|}
\hline & & $\begin{array}{l}\text { downloads did not vary across the } \\
\text { types of programming language. } \\
\text { Results of One-Way ANOVA test } \\
\text { showed that average number of } \\
\text { downloads did not vary across the } \\
\text { types of programming language } \\
\text { and were not significant at } p<0.1 \text {. }\end{array}$ \\
\hline $\begin{array}{l}\text { Hypothesis } \mathbf{4 b} \text {. Using a commonly } \\
\text { used programming language is } \\
\text { positively associated with the } \\
\text { number of releases of OSS } \\
\text { projects. }\end{array}$ & Not supported & $\begin{array}{l}\text { In multivariate GLM the effect of } \\
\text { programming language type on } \\
\text { number of releases is not } \\
\text { significant because Pillai's trace, } \\
\text { Wilk's lambda, Hotelling's trace, } \\
\text { Roy's largest root and F statistics } \\
\text { for these are not significant at p < } \\
0.1 \text {. Therefore, average number of } \\
\text { releases did not vary across the } \\
\text { types of programming language. } \\
\text { Results of Welch and Brown- } \\
\text { Forsythe robust F tests showed } \\
\text { that average number of releases } \\
\text { programming language and were }\end{array}$ \\
\hline
\end{tabular}




\begin{tabular}{|c|c|c|}
\hline & & not significant at $\mathrm{p}<0.1$. \\
\hline $\begin{array}{l}\text { Hypothesis 5a. Development of } \\
\text { application development and } \\
\text { deployment tools is positively } \\
\text { associated with the number of } \\
\text { downloads of OSS projects. }\end{array}$ & Supported & $\begin{array}{l}\text { In multivariate GLM the effect of } \\
\text { software type on number of } \\
\text { downloads is significant because } \\
\text { Pillai's trace, Wilk's lambda, } \\
\text { Hotelling's trace and F statistics } \\
\text { for these are significant at } p<0.01 \\
\text { with observed power equal to } 0.91 \\
\text { and coefficient equal to } 0.022 \text {. } \\
\text { Roy's largest root and its F } \\
\text { statistic is significant at } p<0.05 \\
\text { with observed power equal to } \\
0.947 \text { and coefficient equal to } \\
0.026 \text {. Therefore, average number } \\
\text { of downloads varied across the } \\
\text { types of software. Results of } \\
\text { Bonferroni test showed that } \\
\text { average number of downloads was } \\
\text { greater for development of } \\
\text { application development and } \\
\text { deployment tools than those of } \\
\text { system infrastructure software and } \\
\text { application software and were } \\
\text { significant at } p<0.01 \text {. } \\
\text { Results of One-Way ANOVA test } \\
\text { showed that average number of } \\
\text { downloads varied across the types } \\
\text { of software and were significant at }\end{array}$ \\
\hline
\end{tabular}




\begin{tabular}{|c|c|c|}
\hline & & $\begin{array}{l}\mathrm{p}<0.01 . \text { Results of Bonferroni } \\
\text { test showed that average number } \\
\text { of downloads was greater for } \\
\text { development of application } \\
\text { development and deployment tools } \\
\text { than those of system infrastructure } \\
\text { software and application software } \\
\text { and were significant at } p<0.01\end{array}$ \\
\hline $\begin{array}{l}\text { Hypothesis } \mathbf{5 b} \text {. Development of } \\
\text { application development and } \\
\text { deployment tools is positively } \\
\text { associated with the number of } \\
\text { releases of OSS projects. }\end{array}$ & Supported & $\begin{array}{l}\text { In multivariate GLM the effect of } \\
\text { software type on number of } \\
\text { releases is significant because } \\
\text { Pillai's trace, Wilk's lambda, } \\
\text { Hotelling's trace and F statistics } \\
\text { for these are significant at } p<0.01 \\
\text { with observed power equal to } 0.91 \\
\text { and coefficient equal to } 0.022 . \\
\text { Roy's largest root and its F } \\
\text { statistic is significant at } p<0.05 \\
\text { with observed power equal to } \\
0.947 \text { and coefficient equal to } \\
0.026 \text {. Therefore, average number } \\
\text { of releases varied across the types } \\
\text { of software. Results of Bonferroni } \\
\text { test showed that average number } \\
\text { of releases was greater for } \\
\text { development of application } \\
\text { development and deployment tools } \\
\text { than those of system infrastructure } \\
\text { software and application software }\end{array}$ \\
\hline
\end{tabular}




\begin{tabular}{|c|c|c|}
\hline & & $\begin{array}{l}\text { and were significant at } \mathrm{p}<0.01 \text {. } \\
\text { Results of One-Way ANOVA test } \\
\text { showed that average number of } \\
\text { releases varied across the types of } \\
\text { software and were significant at } \mathrm{p} \\
<0.01 \text {. Results of Bonferroni test } \\
\text { showed that average number of } \\
\text { releases was greater for } \\
\text { development of application } \\
\text { development and deployment tools } \\
\text { than those of system infrastructure } \\
\text { software and application software } \\
\text { and were significant at } \mathrm{p}<0.01 \text {. }\end{array}$ \\
\hline $\begin{array}{l}\text { Hypothesis 6a. Use of non- } \\
\text { restrictive license is positively } \\
\text { associated with the number of } \\
\text { downloads of OSS projects. }\end{array}$ & Not supported & $\begin{array}{l}\text { In multivariate GLM the effect of } \\
\text { type of license on number of } \\
\text { downloads is not significant } \\
\text { because Pillai's trace, Wilk's } \\
\text { lambda, Hotelling's trace, Roy's } \\
\text { largest root and F statistics for } \\
\text { these are not significant at } p<0.1 . \\
\text { Therefore, average number of } \\
\text { downloads did not vary across the } \\
\text { types of license. } \\
\text { Results of Welch and Brown- } \\
\text { Forsythe robust F tests showed } \\
\text { that average number of downloads } \\
\text { varied across the types of license }\end{array}$ \\
\hline
\end{tabular}




\begin{tabular}{|c|c|c|}
\hline & & $\begin{array}{l}\text { and were significant at } \mathrm{p}<0.05 \text {. } \\
\text { Results of Tamhane } \mathrm{T} 2 \text { test } \\
\text { showed that average number of } \\
\text { releases was greater for use of } \\
\text { non-restrictive OSS license than } \\
\text { those for use of very restrictive } \\
\text { ones and were significant at } \mathrm{p}< \\
0.1 \text {. }\end{array}$ \\
\hline $\begin{array}{l}\text { Hypothesis } 6 \mathbf{b} \text {. Use of non- } \\
\text { restrictive license is positively } \\
\text { associated with the number of } \\
\text { releases of OSS projects. }\end{array}$ & Not supported & $\begin{array}{l}\text { In multivariate GLM the effect of } \\
\text { type of license on number of } \\
\text { releases is not significant because } \\
\text { Pillai's trace, Wilk's lambda, } \\
\text { Hotelling's trace, Roy's largest } \\
\text { root and F statistics for these are } \\
\text { not significant at } p<0.1 \text {. } \\
\text { Therefore, average number of } \\
\text { releases did not vary across the } \\
\text { types of license. }\end{array}$ \\
\hline & & $\begin{array}{l}\text { Results of One-Way ANOVA test } \\
\text { showed that average number } \\
\text { releases varied across the types of } \\
\text { license and were significant at } p< \\
0.01 \text {. Results of Bonferroni test } \\
\text { showed that average number of }\end{array}$ \\
\hline
\end{tabular}




\begin{tabular}{|l|l|}
\hline & $\begin{array}{l}\text { releases was greater for use of } \\
\text { non-restrictive OSS license than } \\
\text { those for use of very restrictive } \\
\text { ones and were significant at } \mathrm{p}< \\
0.01 .\end{array}$ \\
\hline
\end{tabular}

\subsection{Production/stable and mature OSS projects}

A sub-sample of 108 OSS projects that held a production/stable or mature status was drawn for the total sample of 350 projects. Multivariate GLM was used to examine the relationship between the six factors assumed to contribute to OSS project success and the two measures of OSS project success.

Table 35 provides the results of the Levene's test.

The results of Table 35 indicate that the Levene statistic is significant for number of downloads and not significant for number of releases. Therefore, the variance of the number of downloads is not equal across target user types, programming language types, software types, and license types. Whereas, the variance of the number of releases is equal across target user types, programming language types, software types, and license types. 
Table 35. Levene's test for homogeneity of variances for number of downloads and number of releases across target users types, programming language types, software types, and types of license

$($ Sample size $=108)$

\begin{tabular}{|r|c|c|c|}
\hline & Levene statistic & df1 & df2 \\
\hline $\begin{array}{r}\text { Number of } \\
\text { downloads (QRT) }\end{array}$ & $\begin{array}{c}4.627(* * *) \\
.000\end{array}$ & 17 & 90 \\
\hline $\begin{array}{r}\text { Number of releases } \\
(\mathrm{QRT})\end{array}$ & $\begin{array}{l}.669 \\
(.825)\end{array}$ & 17 & 90 \\
\hline $\begin{array}{r}* \mathrm{p} \quad<0.10 \\
* * \mathrm{p} \quad<0.05 \\
* * * \mathrm{p} \quad<0.01\end{array}$
\end{tabular}

The assumption of homogeneity of variances is met for the number of downloads and not met for number of releases. However, GLM is relatively robust against the violation of this assumption when the groups are of not very unequal sample size and the sample size is adequate. Further SPSS adjusts automatically for unequal group sizes.

Table 36 provides the result of the Box's M test.

The results of Table 36 indicate that the Box's M and F statistics are significant (at $\mathrm{p}<$ $0.01)$. Therefore, the covariance between number of downloads and number of releases is not equal across target users types, programming language types, software types, and license types. 
Table 36. Box's $M$ test for homogeneity of covariance between number of downloads and number of releases across target users types, programming language types, software types, and types of license

$($ Sample size $=108)$

\begin{tabular}{|c|c|c|c|}
\hline Box's M & F & df1 & df2 \\
\hline $\begin{array}{c}129.767(* * *) \\
.000\end{array}$ & $\begin{array}{c}3.528(* * *) \\
.000\end{array}$ & 30 & 1684.971 \\
& & & \\
${ }^{*} \mathrm{p} \quad<0.10$ \\
$* * \mathrm{p} \quad<0.05$ \\
$* * * \mathrm{p} \quad<0.01$
\end{tabular}

The assumption of homogeneity of covariances between the number of downloads and the number of releases is not met. However, GLM is relatively robust against the violation of this assumption when the groups are of not very unequal sample size and the sample size is adequate. Further SPSS adjusts automatically for unequal group sizes.

Table 37 provides the results of multivariate GLM. The effect of all independent variables: number of developers, experience of developers, target users type, programming language type, software type, and type of license were observed simultaneously on the two dependent variables: number of downloads and number of releases. Pillai's trace, Wilk's lambda, Hotelling's trace, and Roy's largest root tests were used to examine the data. 
Table 37. Multivariate GLM tests

$($ Sample size $=108)$

\begin{tabular}{|c|c|c|c|c|c|c|c|}
\hline \multicolumn{2}{|c|}{ Effect } & Value & $\mathbf{F}$ & $\begin{array}{l}\text { Hypothesis } \\
\text { df }\end{array}$ & $\begin{array}{c}\text { Error } \\
\text { df }\end{array}$ & $\begin{array}{c}\text { Partial } \\
\text { Eta } \\
\text { squared } \\
\text { coefficient }\end{array}$ & $\begin{array}{c}\text { Observed } \\
\text { power }\end{array}$ \\
\hline \multirow{4}{*}{ Intercept } & Pillai's trace & .888 & $\begin{array}{c}384.31(* * *) \\
\quad(.000)\end{array}$ & 2 & 97 & .888 & 1 \\
\hline & $\begin{array}{l}\text { Wilk's } \\
\text { lambda }\end{array}$ & .112 & $\begin{array}{c}384.31(* * *) \\
(.000)\end{array}$ & 2 & 97 & .888 & 1 \\
\hline & $\begin{array}{l}\text { Hotelling's } \\
\text { trace }\end{array}$ & 7.924 & $\begin{array}{c}384.31(* * *) \\
\quad(.000)\end{array}$ & 2 & 97 & .888 & 1 \\
\hline & $\begin{array}{c}\text { Roy's } \\
\text { largest root }\end{array}$ & 7.924 & $\begin{array}{c}384.31(* * *) \\
\quad(.000)\end{array}$ & 2 & 97 & .888 & 1 \\
\hline \multirow{4}{*}{$\begin{array}{l}\text { Number of } \\
\text { developers }\end{array}$} & Pillai's trace & .010 & $\begin{array}{c}.489 \\
(.615)\end{array}$ & 2 & 97 & .010 & .212 \\
\hline & $\begin{array}{l}\text { Wilk's } \\
\text { lambda }\end{array}$ & .990 & $\begin{array}{c}.489 \\
(.615)\end{array}$ & 2 & 97 & .010 & .212 \\
\hline & $\begin{array}{l}\text { Hotelling's } \\
\text { trace }\end{array}$ & .010 & $\begin{array}{c}.489 \\
(.615)\end{array}$ & 2 & 97 & .010 & .212 \\
\hline & $\begin{array}{c}\text { Roy's } \\
\text { largest root }\end{array}$ & .010 & $\begin{array}{c}.489 \\
(.615)\end{array}$ & 2 & 97 & .010 & .212 \\
\hline \multirow[t]{2}{*}{$\begin{array}{l}\text { Experience of } \\
\text { developers }\end{array}$} & Pillai's trace & .005 & $\begin{array}{c}.242 \\
(.785)\end{array}$ & 2 & 97 & .005 & .155 \\
\hline & $\begin{array}{l}\text { Wilk's } \\
\text { lambda }\end{array}$ & .995 & $\begin{array}{c}.242 \\
(.785)\end{array}$ & 2 & 97 & .005 & .155 \\
\hline
\end{tabular}




\begin{tabular}{|c|c|c|c|c|c|c|c|}
\hline & $\begin{array}{l}\text { Hotelling's } \\
\text { trace }\end{array}$ & .005 & $\begin{array}{c}.242 \\
(.785)\end{array}$ & 2 & 97 & .005 & .155 \\
\hline & $\begin{array}{l}\text { Roy's } \\
\text { largest root }\end{array}$ & .005 & $\begin{array}{l}.242 \\
(.785)\end{array}$ & 2 & 97 & .005 & .155 \\
\hline \multirow{4}{*}{$\begin{array}{r}\text { Target users } \\
\text { type }\end{array}$} & Pillai's trace & .059 & $\begin{array}{l}1.480 \\
(.210)\end{array}$ & 4 & 196 & .029 & .584 \\
\hline & $\begin{array}{l}\text { Wilk's } \\
\text { lambda }\end{array}$ & .941 & $\begin{array}{l}1.488 \\
(.207)\end{array}$ & 4 & 194 & .030 & .586 \\
\hline & $\begin{array}{l}\text { Hotelling's } \\
\text { trace }\end{array}$ & .062 & $\begin{array}{l}1.495 \\
(.205)\end{array}$ & 4 & 192 & .030 & .588 \\
\hline & $\begin{array}{l}\text { Roy's } \\
\text { largest root }\end{array}$ & .062 & $\begin{array}{c}3.048(*) \\
(.052)\end{array}$ & 2 & 98 & .059 & .699 \\
\hline \multirow{4}{*}{$\begin{array}{l}\text { Programming } \\
\text { language type }\end{array}$} & Pillai's trace & .015 & $\begin{array}{c}.697 \\
(.500)\end{array}$ & 2 & 97 & .014 & .260 \\
\hline & $\begin{array}{l}\text { Wilk's } \\
\text { lambda }\end{array}$ & .986 & $\begin{array}{c}.697 \\
(.500)\end{array}$ & 2 & 97 & .014 & .260 \\
\hline & $\begin{array}{l}\text { Hotelling's } \\
\text { trace }\end{array}$ & .014 & $\begin{array}{c}.697 \\
(.500)\end{array}$ & 2 & 97 & .014 & .260 \\
\hline & $\begin{array}{l}\text { Roy's } \\
\text { largest root }\end{array}$ & .014 & $\begin{array}{c}.697 \\
(.500)\end{array}$ & 2 & 97 & .014 & .260 \\
\hline \multirow[t]{2}{*}{ Software type } & Pillai's trace & .082 & $\begin{array}{c}2.097\left(^{*}\right) \\
(.083)\end{array}$ & 4 & 196 & .041 & .732 \\
\hline & $\begin{array}{l}\text { Wilk's } \\
\text { lambda }\end{array}$ & .919 & $\begin{array}{c}2.099\left(^{*}\right) \\
(.082)\end{array}$ & 4 & 194 & .041 & .733 \\
\hline
\end{tabular}




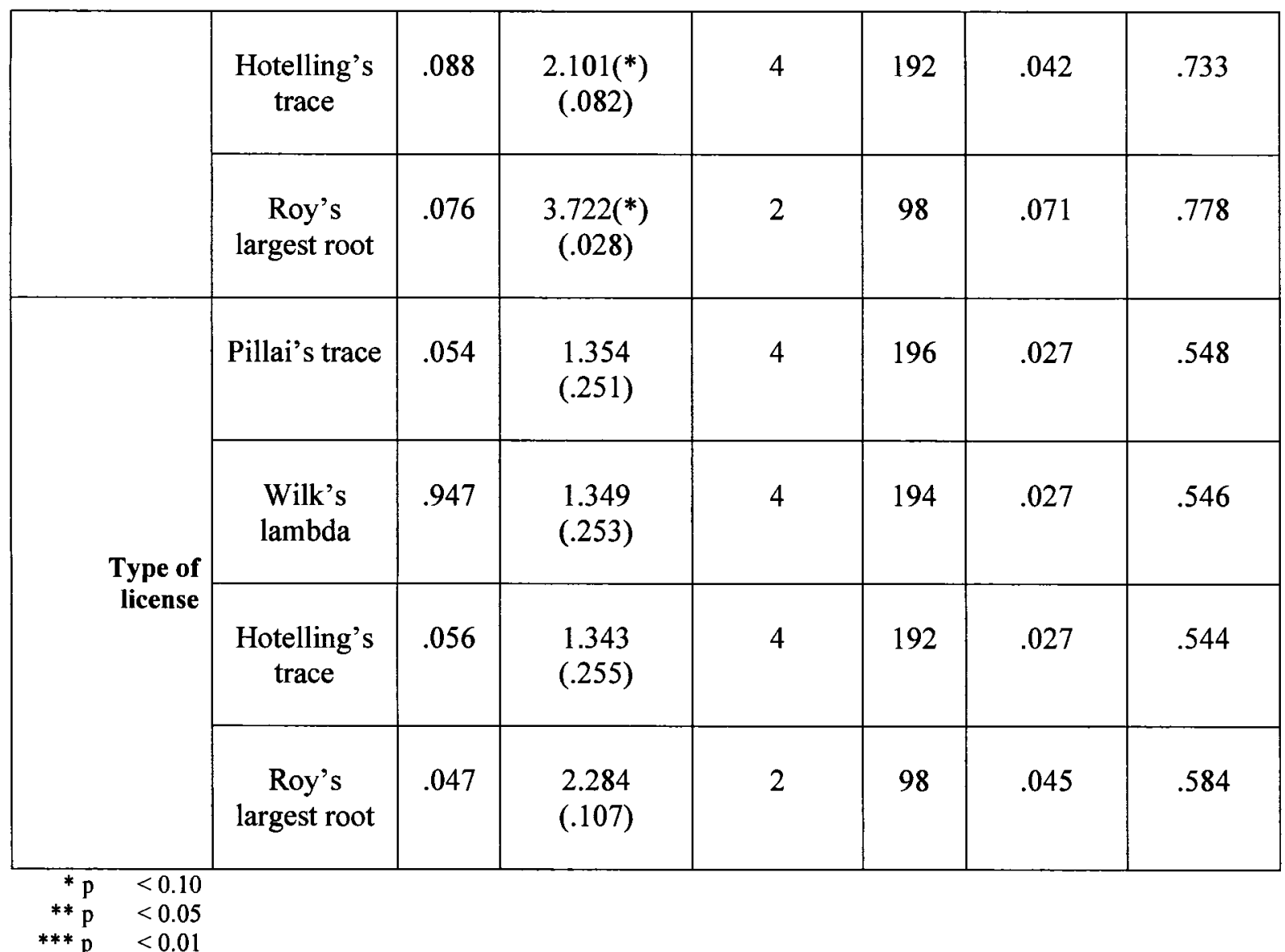

The results of Table 37 suggest that the effect of software type is significant on number of downloads and number of releases. Number of developers, experience of developers, target users type, programming language type and license type used have no significant effect on number of downloads and number of releases.

Table 38 provides multiple comparison results of the Tamhane T2 test. It was used to compare average number of downloads across the types of software because it assumes unequal variances. 
Table 38. Multiple comparisons of average number of downloads across types of software

$($ Sample size $=108)$

Number of downloads (QRT)

\begin{tabular}{|c|c|c|c|c|c|}
\hline \multirow[b]{2}{*}{$\begin{array}{l}\text { (I) Type of } \\
\text { software }\end{array}$} & \multirow[b]{2}{*}{ Mean } & \multirow[b]{2}{*}{$\begin{array}{l}\text { (J) Type of } \\
\text { software }\end{array}$} & \multirow[b]{2}{*}{$\begin{array}{c}\text { Mean } \\
\text { difference } \\
\text { (I-J) }\end{array}$} & \multicolumn{2}{|c|}{$\begin{array}{c}90 \% \text { Confidence } \\
\text { interval }\end{array}$} \\
\hline & & & & $\begin{array}{l}\text { Lower } \\
\text { bound }\end{array}$ & $\begin{array}{l}\text { Upper } \\
\text { bound }\end{array}$ \\
\hline \multirow{2}{*}{$\begin{array}{l}\text { Application } \\
\text { software }\end{array}$} & \multirow[t]{2}{*}{14.7701} & $\begin{array}{c}\text { Application } \\
\text { development and } \\
\text { deployment } \\
\text { tools } \\
\end{array}$ & $\begin{array}{c}-7.0705 \\
(.471)\end{array}$ & -19.1780 & 5.0369 \\
\hline & & $\begin{array}{c}\text { System } \\
\text { infrastructure } \\
\text { software }\end{array}$ & $\begin{array}{c}-6.7243 \\
(.437)\end{array}$ & -19.5758 & 4.7422 \\
\hline \multirow{2}{*}{$\begin{array}{c}\text { Application } \\
\text { development and } \\
\text { deployment tools }\end{array}$} & \multirow{2}{*}{21.8407} & $\begin{array}{l}\text { Application } \\
\text { software }\end{array}$ & $\begin{array}{l}7.0705 \\
(.471)\end{array}$ & -5.0369 & 19.1780 \\
\hline & & $\begin{array}{c}\text { System } \\
\text { infrastructure } \\
\text { software }\end{array}$ & $\begin{array}{l}.3463 \\
(.995)\end{array}$ & -2.9998 & 3.6923 \\
\hline \multirow{2}{*}{$\begin{array}{c}\text { System } \\
\text { infrastructure } \\
\text { software }\end{array}$} & \multirow{2}{*}{21.4944} & $\begin{array}{l}\text { Application } \\
\text { software }\end{array}$ & $\begin{array}{l}6.7243 \\
(.437)\end{array}$ & -4.7422 & 19.5758 \\
\hline & & $\begin{array}{c}\text { Application } \\
\text { development and } \\
\text { deployment } \\
\text { tools } \\
\end{array}$ & $\begin{array}{l}-.3463 \\
(.995)\end{array}$ & -3.6923 & 2.9998 \\
\hline $\begin{array}{rr}*^{*} \mathrm{p} & <0.10 \\
* * \mathrm{p} & <0.05 \\
* * * \mathrm{p} & <0.01\end{array}$ & & & & & \\
\hline
\end{tabular}

Results shown in Table 38 indicate that the difference between average number of downloads across all three types of software is not significant. 
Table 39. Multiple comparisons of average number of releases across software types

$($ Sample size $=108)$

Number of releases (QRT)

\begin{tabular}{|c|c|c|c|c|c|}
\hline \multirow[b]{2}{*}{$\begin{array}{l}\text { (I) Type of } \\
\text { software }\end{array}$} & \multirow[b]{2}{*}{ Mean } & \multirow[b]{2}{*}{$\begin{array}{l}\text { (J) Type of } \\
\text { software }\end{array}$} & \multirow[b]{2}{*}{$\begin{array}{c}\text { Mean } \\
\text { difference } \\
\text { (I-J) }\end{array}$} & \multicolumn{2}{|c|}{$\begin{array}{c}90 \% \text { Confidence } \\
\text { interval }\end{array}$} \\
\hline & & & & $\begin{array}{l}\text { Lower } \\
\text { bound }\end{array}$ & $\begin{array}{l}\text { Upper } \\
\text { bound }\end{array}$ \\
\hline \multirow{2}{*}{$\begin{array}{l}\text { Application } \\
\text { software }\end{array}$} & \multirow[t]{2}{*}{2.2083} & $\begin{array}{c}\text { Application } \\
\text { development and } \\
\text { deployment } \\
\text { tools }\end{array}$ & $\begin{array}{c}-.4153\left(^{*}\right) \\
.058\end{array}$ & -.7917 & -.0388 \\
\hline & & $\begin{array}{c}\text { System } \\
\text { infrastructure } \\
\text { software }\end{array}$ & $\begin{array}{l}-.2433 \\
(.569)\end{array}$ & -.6409 & .1542 \\
\hline \multirow{2}{*}{$\begin{array}{c}\text { Application } \\
\text { development and } \\
\text { deployment tools }\end{array}$} & \multirow{2}{*}{2.6236} & $\begin{array}{l}\text { Application } \\
\text { software }\end{array}$ & $\begin{array}{c}.4153\left(^{*}\right) \\
.058\end{array}$ & .0388 & .7917 \\
\hline & & $\begin{array}{c}\text { System } \\
\text { infrastructure } \\
\text { software }\end{array}$ & $\begin{array}{l}.1719 \\
(.470)\end{array}$ & -.0879 & .4318 \\
\hline \multirow{2}{*}{$\begin{array}{c}\text { System } \\
\text { infrastructure } \\
\text { software }\end{array}$} & \multirow{2}{*}{2.4517} & $\begin{array}{l}\text { Application } \\
\text { software }\end{array}$ & $\begin{array}{l}.2433 \\
(.569)\end{array}$ & -.1542 & .6409 \\
\hline & & $\begin{array}{c}\text { Application } \\
\text { development and } \\
\text { deployment } \\
\text { tools }\end{array}$ & $\begin{array}{l}-.1719 \\
(.470)\end{array}$ & -.4318 & .0879 \\
\hline $\begin{array}{rr}* \mathrm{p} & <0.10 \\
* * \mathrm{p} & <0.05 \\
* * * \mathrm{p} & <0.01\end{array}$ & & & & & \\
\hline
\end{tabular}

Table 39 provides multiple comparison results of Bonferroni test for Hypothesis $5 \mathrm{~b}$. This test was used to compare average number of releases across the types of software because it assumes equal variances. 
The results shown in Table 39 indicate that the average number of releases is greater if the application development and deployment tools are developed instead of system infrastructure software and application software. The results are significant at $\mathrm{p}<0.1$. However, the difference between average number of releases is not significant when the type of OSS software is either system infrastructure software or application software.

Hypothesis 1. Number of developers is positively associated with the success of OSS projects

Hypotheses $1 \mathrm{a}$ and $1 \mathrm{~b}$ posit that number of developers is positively associated with the number of downloads and number of releases of the OSS project respectively.

Table 40. Spearman correlations between number of developers and measures of success of OSS project

$($ Sample size $=108)$

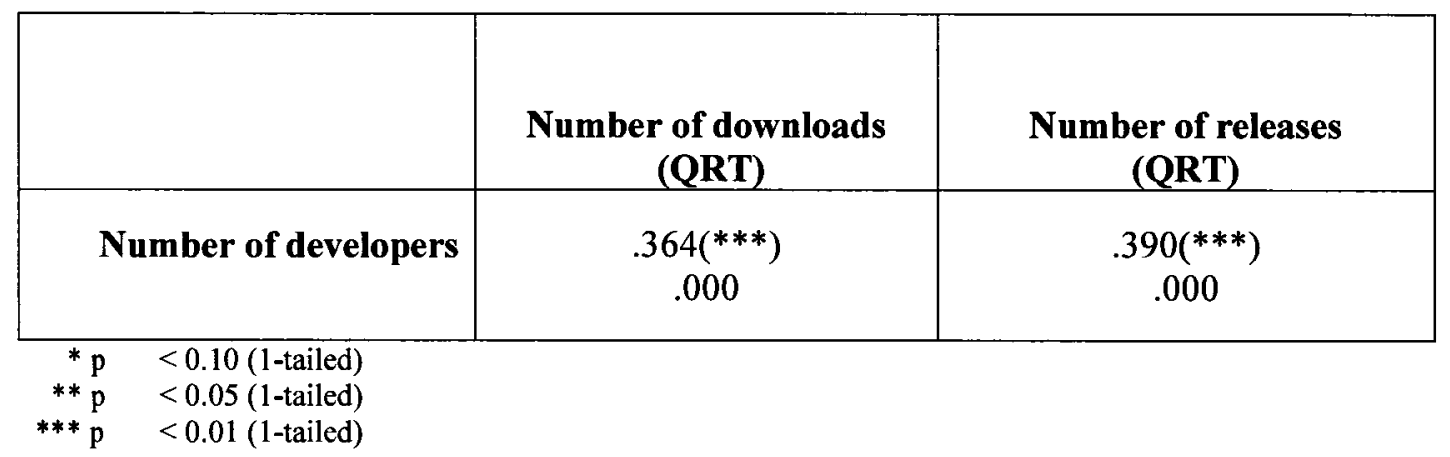

Spearman correlation was used to test Hypotheses 1a and $1 \mathrm{~b}$. Table 40 provides the Spearman correlation coefficients for the number of developers, the number of downloads, and number of releases of OSS project. 
One tailed tests of the alternative Hypothesis at $\mathrm{p}<0.01$ showed the following associations:

- Number of developers is positively associated with the number of downloads of the OSS project

- Number of developers is positively associated with the number of releases of the OSS project

Results shown in Table 40 support Hypotheses $1 \mathrm{a}$ and 1b. This finding contradicts the results shown in Table 37.

\section{Hypothesis 2. Experience of developers is positively associated with the success of OSS projects}

Hypotheses $2 \mathrm{a}$ and $2 \mathrm{~b}$ posit that experience of developers is positively associated with the number of downloads and number of releases of the OSS project respectively.

Spearman correlation was used to test Hypotheses $2 \mathrm{a}$ and $2 \mathrm{~b}$. Table 41 provides the Spearman correlation coefficients for the experience of developers, the number of downloads, and number of releases of OSS project. 
Table 41. Spearman correlations between experience of developers and measures of success of OSS project

$($ Sample size $=108)$

\begin{tabular}{|c|c|c|}
\hline & $\begin{array}{c}\text { Number of downloads } \\
(\text { QRT) }\end{array}$ & $\begin{array}{c}\text { Number of releases } \\
(\mathrm{QRT})\end{array}$ \\
\hline Number of developers & $\begin{array}{c}.318\left(^{* * *}\right) \\
.000\end{array}$ & $\begin{array}{c}.323\left(^{* * *}\right) \\
.000\end{array}$ \\
\hline
\end{tabular}

${ }^{*} \mathrm{p} \quad<0.10(1$-tailed $)$

$* * \mathrm{p} \quad<0.05$ (1-tailed)

$* * * \mathrm{p} \quad<0.01$ (1-tailed)

One tailed tests of the alternative Hypothesis at $\mathrm{p}<0.01$ showed the following associations:

- Number of developers is positively associated with the number of downloads of the OSS project

- Number of developers is positively associated with the number of releases of the OSS project

Results shown in Table 41 support Hypotheses $2 \mathrm{a}$ and $2 \mathrm{~b}$. This finding contradicts the results shown in Table 37. 
Hypothesis 3. Targeting developers as users is positively associated with the success of OSS projects

Hypotheses $3 \mathrm{a}$ and $3 \mathrm{~b}$ posit that targeting developers as users is positively associated with the number of downloads and the number of releases of the OSS project respectively.

To test Hypotheses $3 a$ and $3 b$, the researcher first checked whether or not the variance of the number of downloads and the number of releases is homogeneous across the types of target users. The Levene test of homogeneity of variances was used for this purpose. Table 42 provides the results.

Table 42.' Levene test for homogeneity of variances for number of downloads and number of releases across types of target users

$($ Sample size $=108)$

\begin{tabular}{|r|c|c|c|}
\hline & Levene statistic & df1 & df2 \\
\hline $\begin{array}{r}\text { Number of } \\
\text { downloads (QRT) }\end{array}$ & $\begin{array}{c}21.458(* * *) \\
.000\end{array}$ & 2 & 105 \\
\hline $\begin{array}{r}\text { Number of releases } \\
\text { (QRT) }\end{array}$ & $\begin{array}{c}1.371 \\
(.258)\end{array}$ & 2 & 105 \\
& & & \\
\hline$* \mathrm{p}<0.10$ \\
$* * \mathrm{p}<0.05$ \\
$* * * \mathrm{p}<0.01$
\end{tabular}

Results of Table 42 indicate that the Levene statistic is significant for number of downloads (at $\mathrm{p}<0.01$ ) and not significant for number of releases. Therefore, the 
variance for number of downloads is not equal across target user types. However, variance for number of releases is equal across target users types.

Since the number of downloads have unequal variance, the Welch and Brown-Forsythe robust $F$ tests were used to test hypotheses 3a instead of the One-Way ANOVA (which requires equality of variance). As the number of releases have equal variance, One-Way ANOVA test was used to test Hypothesis $3 b$.

Table 43 provides the results of using the Welch and Brown-Forsythe robust $F$ tests to examine Hypothesis 3a.

Table 43. Welch and Brown-Forsythe robust $F$ tests of equality of means of number of downloads across types of target users

$($ Sample size $=108)$

\begin{tabular}{|c|c|c|c|c|}
\hline & & Statistic & df1 & df2 \\
\hline \multirow{2}{*}{$\begin{array}{r}\text { Number of } \\
\text { downloads (QRT) }\end{array}$} & Welch & $\begin{array}{l}.890 \\
(.421)\end{array}$ & 2 & 30.474 \\
\hline & Brown-Forsythe & $\begin{array}{l}1.512 \\
(.245)\end{array}$ & 2 & 19.518 \\
\hline $\begin{array}{ll}\mathrm{p} & <0.10 \\
\mathrm{p} & <0.05 \\
\mathrm{p} & <0.01\end{array}$ & & & & \\
\hline
\end{tabular}

The null Hypothesis was that the average number of downloads is the same for all three target users types. The results in Table 43 show that the Welch and Brown-Forsythe statistics are not significant. Therefore, the null Hypothesis that the average number of 
downloads is the same for all target users types cannot be rejected. Thus, Hypothesis $3 a$ is not supported. This finding is consistent with the results shown in Table 37.

Table 44 provides the results of the One-Way ANOVA test for Hypothesis $3 \mathrm{~b}$.

Table 44. One-Way ANOVA test of equality of means of number of releases across types of target users

$($ Sample size $=108)$

\begin{tabular}{|c|c|c|c|c|c|}
\hline \multicolumn{2}{|c|}{} & $\begin{array}{c}\text { Sum of } \\
\text { squares }\end{array}$ & df & $\begin{array}{c}\text { Mean } \\
\text { square }\end{array}$ & F \\
\hline \multirow{2}{*}{$\begin{array}{c}\text { Number of } \\
\text { releases (QRT) }\end{array}$} & $\begin{array}{c}\text { Between } \\
\text { groups }\end{array}$ & 1.547 & 2 & .773 & $\begin{array}{r}2.347 \\
(.101)\end{array}$ \\
\cline { 2 - 6 } & Within groups & 34.601 & 105 & .330 & \\
\cline { 2 - 6 } & Total & 36.148 & 107 & & \\
\hline
\end{tabular}

$\begin{array}{rr}* \mathrm{p} & <0.10 \\ { }_{* *} \mathrm{p} & <0.05\end{array}$

$\begin{array}{rr}* * \mathrm{p} & <0.05 \\ * * * \mathrm{p} & <0.01\end{array}$

The null Hypothesis was that the average number of releases is the same for all three target users types. The results in Table 44 indicate that the F statistic is not significant. Therefore, the null Hypothesis that the average number of releases is the same for all categories of target user types cannot be rejected. Thus, Hypothesis $3 \mathrm{~b}$ is not supported. This finding is consistent with the results shown in Table 37. 
Hypothesis 4. Using a commonly used programming language is positively associated with the success of OSS projects

Hypotheses $4 \mathrm{a}$ and $4 \mathrm{~b}$ posit that the use of a commonly used programming language is positively associated with the number of downloads and the number of releases of the OSS project respectively.

To test hypotheses $4 \mathrm{a}$ and $4 \mathrm{~b}$, the researcher first checked whether or not the variance of the number of downloads and the number of releases is homogeneous across the two programming language types. Table 45 provides the results of using the Levene test of homogeneity of variances.

Table 45. Levene test for homogeneity of variances for number of downloads and number of releases across programming language types

$($ Sample size $=108)$

\begin{tabular}{|r|c|c|c|}
\hline & Levene statistic & df1 & df2 \\
\hline $\begin{array}{r}\text { Number of } \\
\text { downloads (QRT) }\end{array}$ & $\begin{array}{c}.126 \\
(.724)\end{array}$ & 1 & 106 \\
\hline $\begin{array}{r}\text { Number of releases } \\
\text { (QRT) }\end{array}$ & $\begin{array}{c}2.802 \\
.097\left(^{*}\right)\end{array}$ & 1 & 106 \\
$\begin{array}{r}{ }^{*} \mathrm{p}<0.10 \\
* * \quad \mathrm{p}<0.05 \\
* * * \mathrm{p}<0.01\end{array}$ & & \\
\hline
\end{tabular}

Results of Table 45 indicate that the Levene statistic is not significant for number of downloads and is significant for number of releases (at $\mathrm{p}<0.1$ ). Therefore, the variance 
for number of downloads is equal across the two programming language types. However, variance for number of releases is not equal across programming language type.

Since the number of downloads have equal variance, the One-Way ANOVA test was used to test Hypotheses 4a. As the number of releases have unequal variance, Welch and Brown-Forsythe robust $\mathrm{F}$ tests were used to test Hypothesis $4 \mathrm{~b}$.

Table 46 provides the results of using the One-way ANOVA test to examine Hypothesis 4a.

Table 46. One-Way ANOVA test of equality of means of number of downloads across programming language types

$($ Sample size $=108)$

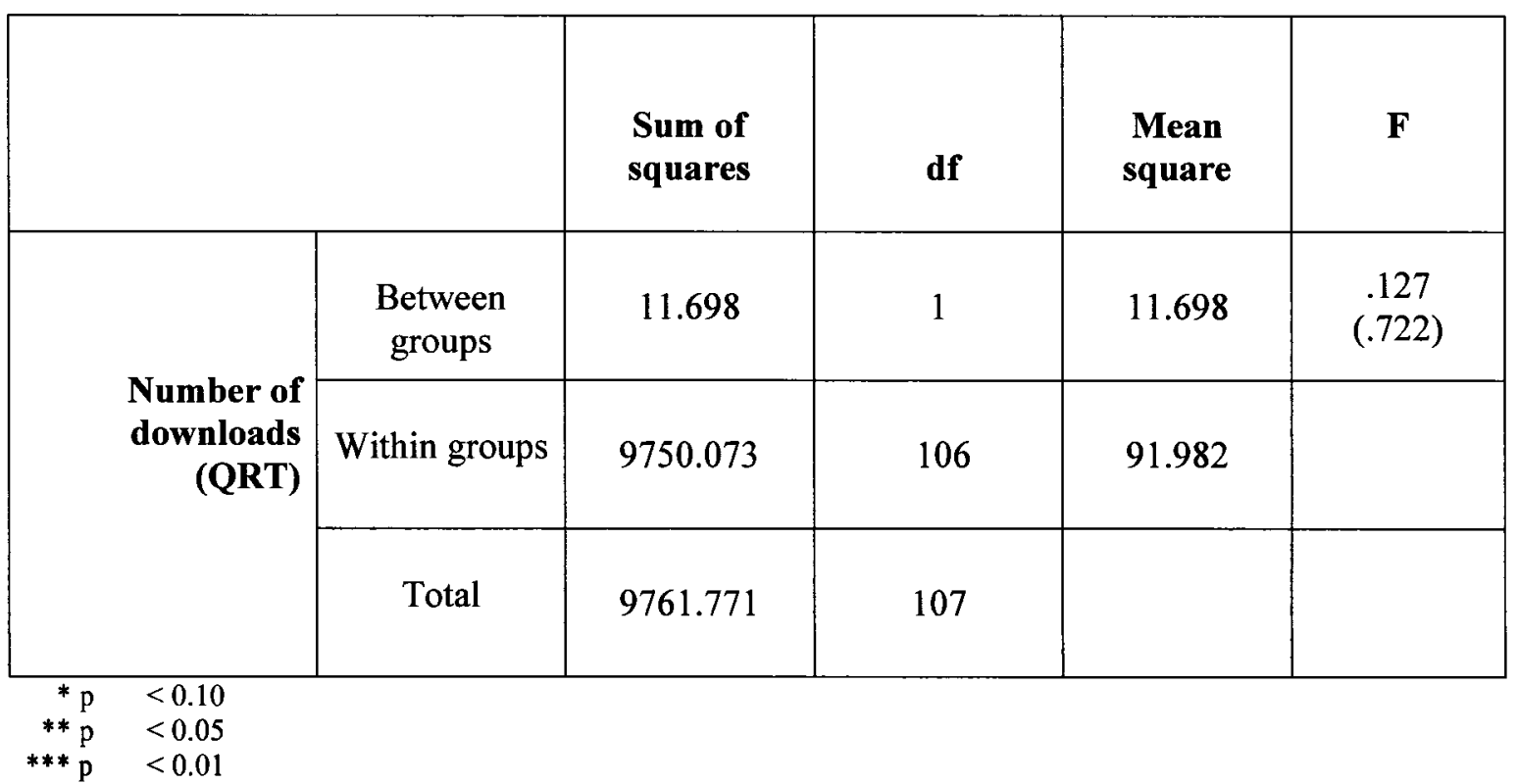

The null Hypothesis was that the average number of downloads is the same for the two types of programming languages. Results in Table 46 indicate that the F statistic is not 
significant. Therefore, the null Hypothesis that the average number of downloads is the same for all types of programming language cannot be rejected. Thus, Hypothesis $4 \mathrm{a}$ is not supported. This is consistent with the results shown in Table 37.

Table 47 provides the results of the Welch and Brown-Forsyth robust $F$ tests used to examine Hypothesis $4 b$.

Table 47. Welch and Brown-Forsyth robust $F$ tests of equality of means of number of releases across programming language types

$($ Sample size $=108)$

\begin{tabular}{|c|c|c|c|c|}
\hline & & Statistic & df1 & df2 \\
\hline \multirow{2}{*}{$\begin{array}{r}\text { Number of } \\
\text { downloads (QRT) }\end{array}$} & Welch & $\begin{array}{c}4.237 \\
.142\end{array}$ & 1 & 89.297 \\
\hline & Brown-Forsythe & $\begin{array}{c}4.237 \\
.142\end{array}$ & 1 & 89.297 \\
\hline $\begin{array}{ll}{ }^{*} p & <0.10 \\
{ }^{*} p & <0.05 \\
{ }^{p} p & <0.01\end{array}$ & & & & \\
\hline
\end{tabular}

The null Hypothesis was that the average number of releases is the same for all types of programming language. The results shown in Table 47 indicate that the Welch and Brown-Forsyth statistics are not significant. Therefore, the null Hypothesis that the average number of releases is the same for all types of programming language cannot be rejected. Thus, Hypothesis $4 \mathrm{~b}$ is not supported. This finding is consistent with the results shown in Table 37. 
Hypothesis 5. Development of application development and deployment tools is positively associated with the success of OSS projects

Hypotheses $5 \mathrm{a}$ and $5 \mathrm{~b}$ posit that the development of application development and deployment tools is positively associated with the number of downloads and number of releases of OSS project respectively.

To test hypotheses $5 \mathrm{a}$ and $5 \mathrm{~b}$, the researcher first checked whether or not the variance of number of downloads and number of releases is homogeneous across the types of software. Table 48 provides the results of using the Levene test of homogeneity of variances.

Table 48. Levene test for homogeneity of variances for number of downloads and number of releases across types of software

$($ Sample size $=108)$

\begin{tabular}{|c|c|c|c|}
\hline & Levene statistic & df1 & df 2 \\
\hline $\begin{array}{r}\text { Number of } \\
\text { downloads (QRT) }\end{array}$ & $\begin{array}{l}23.655(* * *) \\
(.000)\end{array}$ & 2 & 105 \\
\hline $\begin{array}{r}\text { Number of releases } \\
\text { (QRT) }\end{array}$ & $\begin{array}{l}2.347 \\
(.101)\end{array}$ & 2 & 105 \\
\hline $\begin{array}{rr}{ }^{*} \mathrm{p} & <0.10 \\
* * \mathrm{p} & <0.05 \\
* * * \mathrm{p} & <0.01\end{array}$ & & & \\
\hline
\end{tabular}

Results of Table 48 indicate that the Levene statistic is significant for number of downloads (at $\mathrm{p}<0.01$ ) and not significant for number of releases. Therefore, the 
variance for number of downloads is not equal across software types. However, variance for number of releases is equal across software types.

Since the number of downloads have unequal variance, the Welch and Brown-Forsythe robust $\mathrm{F}$ tests were used to test hypotheses $5 \mathrm{a}$ instead of the One-Way ANOVA (which requires equality of variance). As the number of releases have equal variance, One-Way ANOVA test was used to test Hypothesis $5 b$.

Table 49 provides the results of using the Welch and Brown-Forsythe robust $F$ tests to examine Hypothesis 5a.

Table 49. Welch and Brown-Forsythe robust $F$ tests of equality of means of number of downloads across types of software

$($ Sample size $=108)$

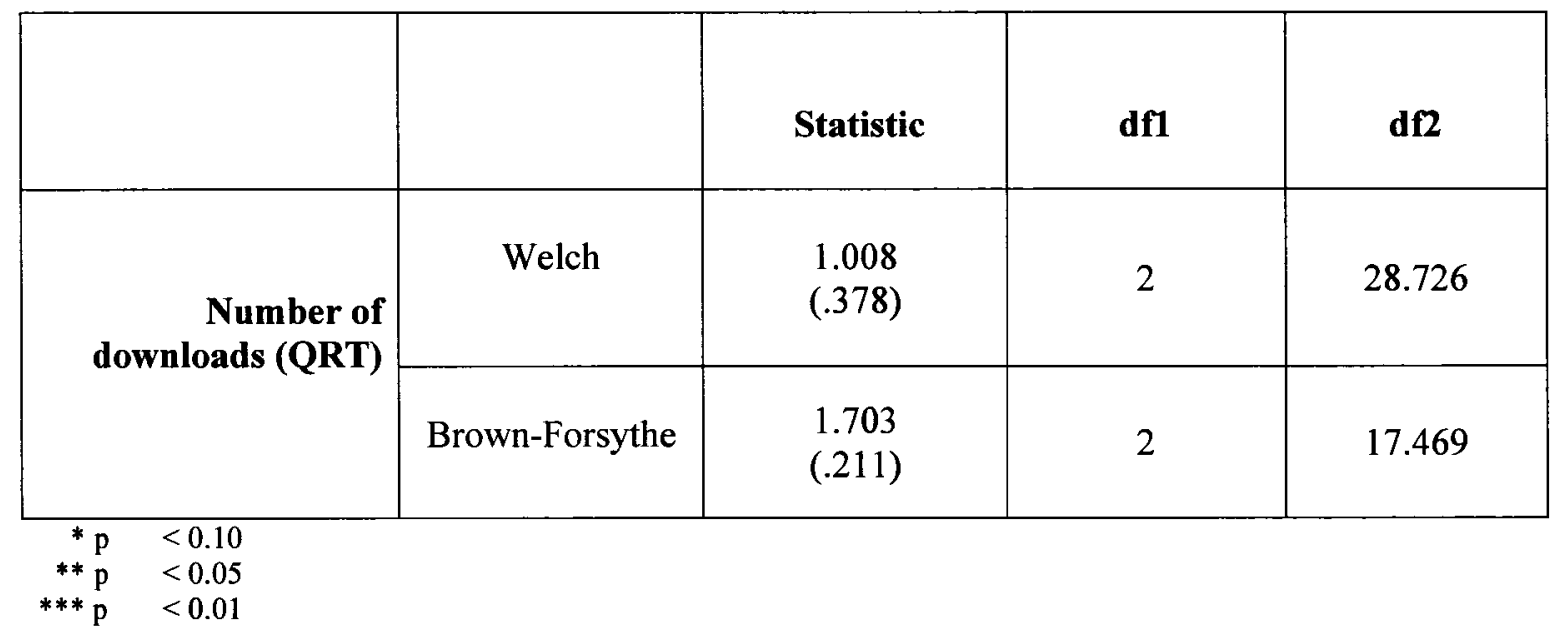

The null Hypothesis was that the average number of downloads is the same for all three software types. The results in Table 49 show that the Welch and Brown-Forsythe statistics are not significant. Therefore, the null Hypothesis that the average number of 
downloads is the same for all software types cannot be rejected. Thus, Hypothesis $5 \mathrm{a}$ is not supported. This finding is not consistent with the results shown in Table 37.

Table 50 provides the results of the One-Way ANOVA test for Hypothesis $5 \mathrm{~b}$.

Table 50. One-Way ANOVA test of equality of means of number of releases across types of software

$($ Sample size $=108)$

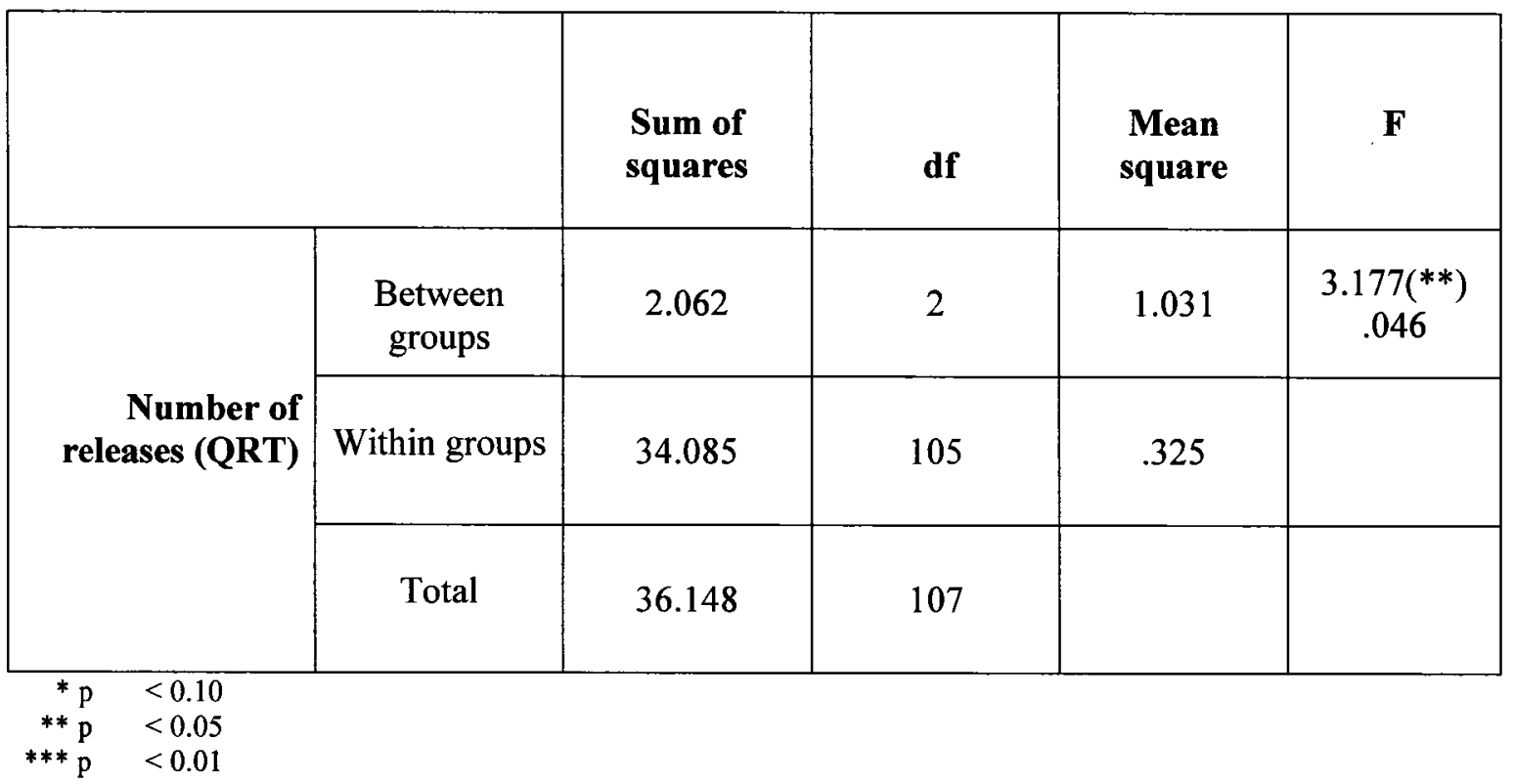

The null Hypothesis was that the average number of releases is the same for all three software types. The results in Table 50 indicate that the $\mathrm{F}$ statistic is significant. Therefore, the null Hypothesis that the average number of releases is the same for all categories of target user types can be rejected. 
Table 51 provides multiple comparison results of Bonferroni test for Hypothesis $5 \mathrm{~b}$. This test was used to compare average number of releases across the types of software because it assumes equal variances.

Table 51. Multiple comparisons of average number of releases across software types

$($ Sample size $=108)$

Number of releases $(\mathrm{QRT})$

\begin{tabular}{|c|c|c|c|c|c|}
\hline \multirow[b]{2}{*}{$\begin{array}{l}\text { (I) Type of } \\
\text { software }\end{array}$} & \multirow[b]{2}{*}{ Mean } & \multirow[b]{2}{*}{$\begin{array}{l}\text { (J) Type of } \\
\text { software }\end{array}$} & \multirow[b]{2}{*}{$\begin{array}{c}\text { Mean } \\
\text { difference } \\
(I-J)\end{array}$} & \multicolumn{2}{|c|}{$\begin{array}{c}90 \% \text { Confidence } \\
\text { interval }\end{array}$} \\
\hline & & & & $\begin{array}{l}\text { Lower } \\
\text { bound }\end{array}$ & $\begin{array}{l}\text { Upper } \\
\text { bound }\end{array}$ \\
\hline \multirow{2}{*}{$\begin{array}{l}\text { Application } \\
\text { software }\end{array}$} & \multirow[t]{2}{*}{2.2083} & $\begin{array}{c}\text { Application } \\
\text { development and } \\
\text { deployment } \\
\text { tools } \\
\end{array}$ & $\begin{array}{c}-.4153\left({ }^{*}\right) \\
.058\end{array}$ & -.7917 & -.0388 \\
\hline & & $\begin{array}{c}\text { System } \\
\text { infrastructure } \\
\text { software }\end{array}$ & $\begin{array}{l}-.2433 \\
(.569)\end{array}$ & -.6409 & .1542 \\
\hline \multirow{2}{*}{$\begin{array}{c}\text { Application } \\
\text { development and } \\
\text { deployment tools }\end{array}$} & \multirow{2}{*}{2.6236} & $\begin{array}{l}\text { Application } \\
\text { software }\end{array}$ & $\begin{array}{c}.4153\left(^{*}\right) \\
.058\end{array}$ & .0388 & .7917 \\
\hline & & $\begin{array}{c}\text { System } \\
\text { infrastructure } \\
\text { software } \\
\end{array}$ & $\begin{array}{l}.1719 \\
(.470)\end{array}$ & -.0879 & .4318 \\
\hline \multirow{2}{*}{$\begin{array}{c}\text { System } \\
\text { infrastructure } \\
\text { software }\end{array}$} & \multirow{2}{*}{2.4517} & $\begin{array}{l}\text { Application } \\
\text { software }\end{array}$ & $\begin{array}{l}.2433 \\
(.569)\end{array}$ & -.1542 & .6409 \\
\hline & & $\begin{array}{c}\text { Application } \\
\text { development and } \\
\text { deployment } \\
\text { tools }\end{array}$ & $\begin{array}{l}-.1719 \\
(.470)\end{array}$ & -.4318 & .0879 \\
\hline $\begin{aligned}{ }^{*} \mathrm{p} & <0.10 \\
* * \mathrm{p} & <0.05 \\
* * * \mathrm{p} & <0.01\end{aligned}$ & & & & & \\
\hline
\end{tabular}


The results shown in Table 51 indicate that the average number of releases is greater if the application development and deployment tools are developed instead of system infrastructure software and application software. The results are significant at $\mathrm{p}<0.1$. However, the difference between average number of releases is not significant when the type of OSS software is either system infrastructure software or application software. These results indicate support for Hypothesis $5 \mathrm{~b}$. This is consistent with the results shown in Table 37.

\section{Hypothesis 6. Use of non-restrictive OSS license is positively associated with the success of OSS projects}

Hypotheses $6 \mathrm{a}$ and $6 \mathrm{~b}$ posit that use of non-restrictive OSS license is positively associated with the number of downloads and the number of releases of the OSS project respectively.

To test Hypotheses $6 \mathrm{a}$ and $6 \mathrm{~b}$, the researcher first checked whether or not the variance of the number of downloads and the number of releases is homogeneous across the types of target users. The Levene test of homogeneity of variances was used for this purpose. Table 52 provides the results. 
Table 52. Levene test for homogeneity of variances for number of downloads and number of releases across types of license

$($ Sample size $=108)$

\begin{tabular}{|r|c|c|c|}
\hline & Levene statistic & df1 & df2 \\
\hline $\begin{array}{r}\text { Number of } \\
\text { downloads (QRT) }\end{array}$ & $\begin{array}{c}3.057\left(^{* *}\right) \\
.050\end{array}$ & 2 & 105 \\
\hline $\begin{array}{r}\text { Number of releases } \\
\text { (QRT) }\end{array}$ & $\begin{array}{c}.448 \\
(.640)\end{array}$ & 2 & 105 \\
$\begin{aligned} * \mathrm{p} \quad<0.10 \\
* * \mathrm{p} \quad<.05 \\
* * * \mathrm{p} \quad<0.01\end{aligned}$
\end{tabular}

Results of Table 52 indicate that the Levene statistic is significant for number of downloads (at $\mathrm{p}<0.05$ ) and not significant for number of releases. Therefore, the variance for number of downloads is not equal across license types. However, variance for number of releases is equal across license types.

Since the number of downloads have unequal variance, the Welch and Brown-Forsythe robust $\mathrm{F}$ tests were used to test hypotheses $6 \mathrm{a}$ instead of the One-Way ANOVA (which requires equality of variance). As the number of releases have equal variance, One-Way ANOVA test was used to test Hypothesis $6 \mathrm{~b}$.

Table 53 provides the results of using the Welch and Brown-Forsythe robust $\mathrm{F}$ tests to examine Hypothesis 6a. 
Table 53. Welch and Brown-Forsythe robust $F$ tests of equality of means of number of downloads across types of license

$($ Sample size $=108)$

\begin{tabular}{|r|c|c|c|c|}
\hline & & Statistic & df1 & df2 \\
\hline $\begin{array}{r}\text { Number of } \\
\text { downloads (QRT) }\end{array}$ & Welch & $\begin{array}{l}1.929 \\
(.154)\end{array}$ & 2 & 60.686 \\
\cline { 2 - 5 } & Brown-Forsythe & $\begin{array}{l}2.517 \\
(.101)\end{array}$ & 2 & 95.094 \\
\hline
\end{tabular}

$* \mathrm{p}<0.10$

$* * \mathrm{p}<0.05$

$* * * \mathrm{p} \quad<0.01$

The null Hypothesis was that the average number of downloads is the same for all three tlicense types. The results in Table 53 show that the Welch and Brown-Forsythe statistics are not significant. Therefore, the null Hypothesis that the average number of downloads is the same for all license types cannot be rejected. Thus Hypothesis $6 \mathrm{a}$ is not supported. This is consistent with the results shown in Table 37.

Table 54 provides the results of the One-Way ANOVA test for Hypothesis $6 \mathrm{~b}$. 
Table 54. One-Way ANOVA test of equality of means of number of releases across types of license

$($ Sample size $=108)$

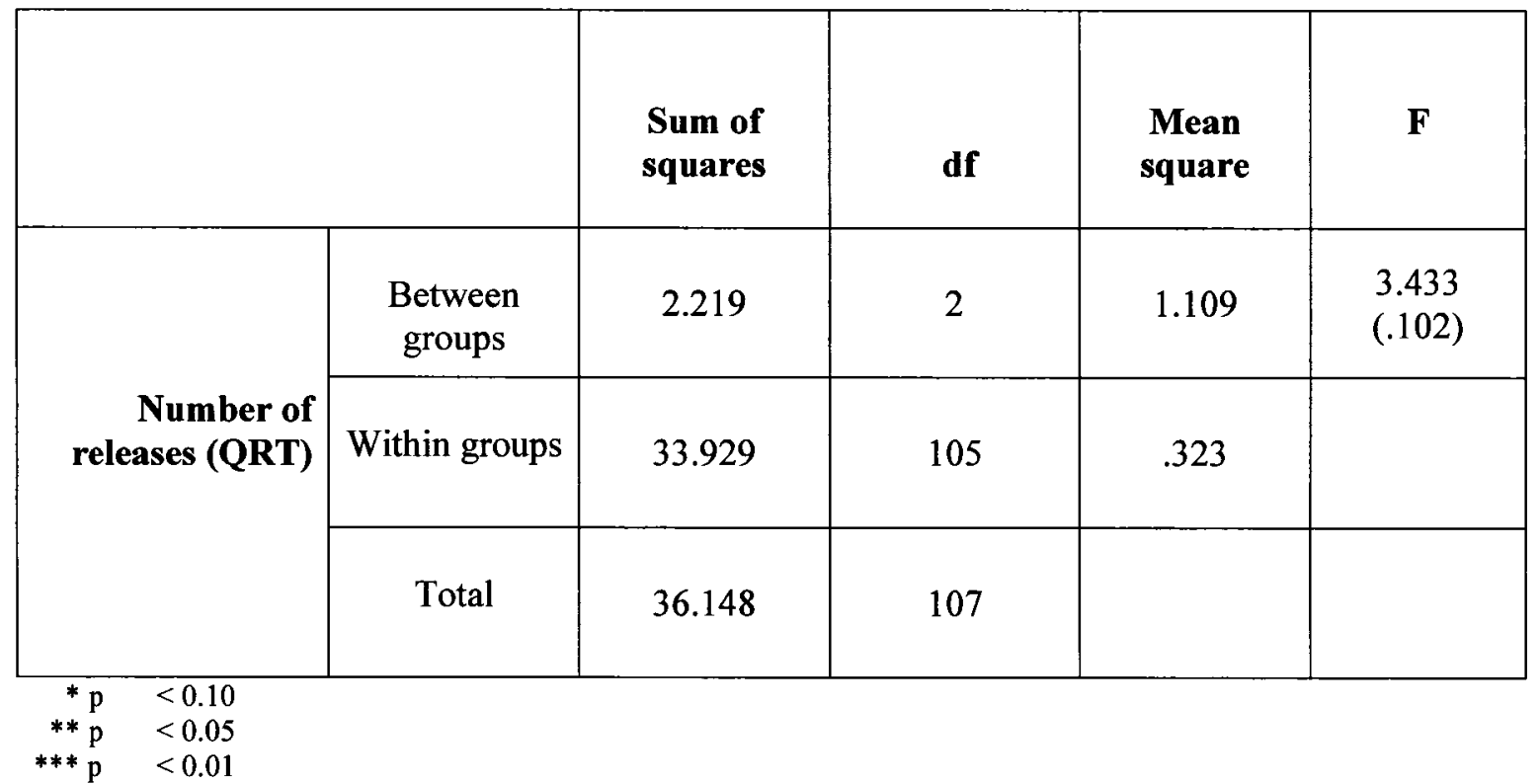

The null Hypothesis was that the average number of releases is the same for all three license types. The results in Table 54 indicate that the F statistic is not significant.

Therefore, the null Hypothesis that the average number of releases is the same for all categories of license types cannot be rejected. Thus, Hypothesis $6 \mathrm{~b}$ is not supported. This finding is consistent with the results shown in Table 37.

Table 55 provides a summary of the results of testing the six hypotheses using the sub sample comprised of 108 projects with development status of production/stable and mature. 
Table 55. Summary of test results organized by hypothesis

(Sample N = 108)

\begin{tabular}{|c|c|c|}
\hline Hypothesis & $\begin{array}{l}\text { Decision based } \\
\text { on test results }\end{array}$ & Rationale \\
\hline $\begin{array}{l}\text { Hypothesis 1a. Number of } \\
\text { developers is positively associated } \\
\text { with the number of downloads of } \\
\text { OSS projects. }\end{array}$ & Not supported & $\begin{array}{l}\text { In multivariate GLM the effect of } \\
\text { number of developers on number } \\
\text { of downloads is not significant } \\
\text { because Pillai's trace, Wilk's } \\
\text { lambda, Hotelling's trace, Roy's } \\
\text { largest root and F statistics for } \\
\text { these are not significant at } p<0.1 \text {. } \\
\text { Spearman correlation coefficient } \\
\text { between number of developers and } \\
\text { number of downloads of OSS } \\
\text { development project was positive } \\
\text { and significant at } p<0.01 \text {. }\end{array}$ \\
\hline $\begin{array}{l}\text { Hypothesis } 1 \mathbf{b} \text {. Number of } \\
\text { developers is positively associated } \\
\text { with the number of releases of OSS } \\
\text { projects. }\end{array}$ & Not supported & $\begin{array}{l}\text { In multivariate GLM the effect of } \\
\text { number of developers on number } \\
\text { of releases is not significant } \\
\text { because Pillai's trace, Wilk's } \\
\text { lambda, Hotelling's trace, Roy's } \\
\text { largest root and F statistics for } \\
\text { these are not significant at } p<0.1 \text {. } \\
\text { Spearman correlation coefficient } \\
\text { between number of developers and }\end{array}$ \\
\hline
\end{tabular}




\begin{tabular}{|c|c|c|}
\hline & & $\begin{array}{l}\text { number of releases of OSS } \\
\text { development project was positive } \\
\text { and significant at } \mathrm{p}<0.01 \text {. }\end{array}$ \\
\hline $\begin{array}{l}\text { Hypothesis } 2 \text { a. Experience of } \\
\text { developers is positively associated } \\
\text { with the number of downloads of } \\
\text { OSS projects. }\end{array}$ & Not supported & $\begin{array}{l}\text { In multivariate GLM the effect of } \\
\text { experience of developers on } \\
\text { number of downloads is not } \\
\text { significant because Pillai's trace, } \\
\text { Wilk's lambda, Hotelling's trace, } \\
\text { Roy's largest root and F statistics } \\
\text { for these are not significant at } p< \\
0.1 \text {. } \\
\text { Spearman correlation coefficient } \\
\text { between experience of developers } \\
\text { and number of downloads of OSS } \\
\text { development project was positive } \\
\text { and significant at } p<0.01 \text {. }\end{array}$ \\
\hline $\begin{array}{l}\text { Hypothesis } \mathbf{2 b} \text {. Experience of } \\
\text { developers is positively associated } \\
\text { with the number of releases of OSS } \\
\text { projects. }\end{array}$ & Not supported & $\begin{array}{l}\text { In multivariate GLM the effect of } \\
\text { experience of developers on } \\
\text { number of releases is not } \\
\text { significant because Pillai's trace, } \\
\text { Wilk's lambda, Hotelling's trace, } \\
\text { Roy's largest root and F statistics } \\
\text { for these are not significant at } p< \\
0.1 \text {. }\end{array}$ \\
\hline & & Spearman correlation coefficient \\
\hline
\end{tabular}




\begin{tabular}{|c|c|c|}
\hline & & $\begin{array}{l}\text { between experience of developers } \\
\text { and number of releases of OSS } \\
\text { development project was positive } \\
\text { and significant at } p<0.01 \text {. }\end{array}$ \\
\hline $\begin{array}{l}\text { Hypothesis 3a. Targeting } \\
\text { developers as users is positively } \\
\text { associated with the number of } \\
\text { downloads of OSS projects. }\end{array}$ & Not supported & $\begin{array}{l}\text { In multivariate GLM the effect of } \\
\text { target users type on number of } \\
\text { downloads is not significant } \\
\text { because Pillai's trace, Wilk's } \\
\text { lambda, Hotelling's trace and F } \\
\text { statistics for these are not } \\
\text { significant at p < } 0.1 \text {. Therefore, } \\
\text { average number of downloads did } \\
\text { not vary across types of target } \\
\text { users. } \\
\text { Results of Welch and Brown- } \\
\text { Forsythe robust F tests showed } \\
\text { that average number of downloads } \\
\text { did not vary across types of target } \\
\text { users and were not significant at } p \\
<0.1 \text {. }\end{array}$ \\
\hline $\begin{array}{l}\text { Hypothesis } 3 \mathbf{b} \text {. Targeting } \\
\text { developers as users is positively } \\
\text { associated with the number of } \\
\text { releases of OSS projects. }\end{array}$ & Not supported & $\begin{array}{l}\text { In multivariate GLM the effect of } \\
\text { target users type on number of } \\
\text { releases is not significant because } \\
\text { Pillai's trace, Wilk's lambda, } \\
\text { Hotelling's trace and F statistics }\end{array}$ \\
\hline
\end{tabular}




\begin{tabular}{|c|c|c|}
\hline & & $\begin{array}{l}\text { for these are not significant at } \mathrm{p}< \\
0.1 \text {. Therefore, average number of } \\
\text { releases did not vary across types } \\
\text { of target users. } \\
\text { Results of One-Way ANOVA test } \\
\text { showed that average number of } \\
\text { releases did not vary across types } \\
\text { of target users and were not } \\
\text { significant at } \mathrm{p}<0.1 .0 .01\end{array}$ \\
\hline $\begin{array}{l}\text { Hypothesis 4a. Using a commonly } \\
\text { used programming language is } \\
\text { positively associated with the } \\
\text { number of downloads of OSS } \\
\text { projects. }\end{array}$ & Not supported & $\begin{array}{l}\text { In multivariate GLM the effect of } \\
\text { programming language type on } \\
\text { number of downloads is not } \\
\text { significant because Pillai's trace, } \\
\text { Wilk's lambda, Hotelling's trace, } \\
\text { Roy's largest root and F statistics } \\
\text { for these are not significant at } p< \\
0.1 \text {. Therefore, average number of } \\
\text { downloads did not vary across the } \\
\text { types of programming language. } \\
\text { Results of One-Way ANOVA test } \\
\text { showed that average number of } \\
\text { downloads did not vary across the } \\
\text { types of programming language } \\
\text { and were not significant at } p<0.1 \text {. }\end{array}$ \\
\hline $\begin{array}{l}\text { Hypothesis } \mathbf{4 b} \text {. Using a commonly } \\
\text { used programming language is }\end{array}$ & Not supported & $\begin{array}{l}\text { In multivariate GLM the effect of } \\
\text { programming language type on }\end{array}$ \\
\hline
\end{tabular}




\begin{tabular}{|c|c|c|}
\hline $\begin{array}{l}\text { positively associated with the } \\
\text { number of releases of OSS } \\
\text { projects. }\end{array}$ & & $\begin{array}{l}\text { number of releases is not } \\
\text { significant because Pillai's trace, } \\
\text { Wilk's lambda, Hotelling's trace, } \\
\text { Roy's largest root and F statistics } \\
\text { for these are not significant at } \mathrm{p}< \\
0.1 \text {. Therefore, average number of } \\
\text { releases did not vary across the } \\
\text { types of programming language. } \\
\text { Results of Welch and Brown- } \\
\text { Forsythe robust F tests showed } \\
\text { that average number of releases } \\
\text { did not vary across the types of } \\
\text { programming language and were } \\
\text { not significant at } \mathrm{p}<0.1 \text {. }\end{array}$ \\
\hline $\begin{array}{l}\text { Hypothesis 5a. Development of } \\
\text { application development and } \\
\text { deployment tools is positively } \\
\text { associated with the number of } \\
\text { downloads of OSS projects. }\end{array}$ & Not supported & $\begin{array}{l}\text { In multivariate GLM the effect of } \\
\text { software type on number of } \\
\text { downloads is significant because } \\
\text { Pillai's trace, Wilk's lambda, } \\
\text { Hotelling's trace and F statistics } \\
\text { for these are significant at p }<0.1 \\
\text { with observed power equal to } 0.7 \\
\text { and coefficient equal to } 0.04 \text {. } \\
\text { Roy's largest root and its F } \\
\text { statistic is significant at } p<0.1 \\
\text { with observed power equal to } \\
0.778 \text { and coefficient equal to } \\
0.071 \text {. Therefore, average number } \\
\text { of downloads varied across the }\end{array}$ \\
\hline
\end{tabular}




\begin{tabular}{|l|l|l|}
\hline & $\begin{array}{l}\text { types of software. Results of } \\
\text { Tamhane T2 test showed that the } \\
\text { difference between average } \\
\text { number of downloads across all } \\
\text { three types of software is not } \\
\text { significant. }\end{array}$ \\
\hline Hypothesis 5b. Development of & Supported \\
application development and \\
deployment tools is positively \\
associated with the number of \\
releases of OSS projects.
\end{tabular}




\begin{tabular}{|c|c|c|}
\hline & & $\begin{array}{l}\text { of releases was greater for } \\
\text { development of application } \\
\text { development and deployment tools } \\
\text { than those of system infrastructure } \\
\text { software and application software } \\
\text { and were significant at } p<0.1 \text {. } \\
\text { Results of One-Way ANOVA test } \\
\text { showed that average number of } \\
\text { releases varied across the types of } \\
\text { software and were significant at } p \\
<0.05 \text {. Results of Bonferroni test } \\
\text { showed that average number of } \\
\text { releases was greater for } \\
\text { development of application } \\
\text { development and deployment tools } \\
\text { than those of system infrastructure } \\
\text { software and application software } \\
\text { and were significant at } p<0.1 .\end{array}$ \\
\hline $\begin{array}{l}\text { Hypothesis 6a. Use of non- } \\
\text { restrictive license is positively } \\
\text { associated with the number of } \\
\text { downloads of OSS projects. }\end{array}$ & Not supported & $\begin{array}{l}\text { In multivariate GLM the effect of } \\
\text { type of license on number of } \\
\text { downloads is not significant } \\
\text { because Pillai's trace, Wilk's } \\
\text { lambda, Hotelling's trace, Roy's } \\
\text { largest root and F statistics for } \\
\text { these are not significant at p }<0.1 \text {. } \\
\text { Therefore, average number of } \\
\text { downloads did not vary across the } \\
\text { types of license. }\end{array}$ \\
\hline
\end{tabular}




\begin{tabular}{|l|l|l|}
\hline & & $\begin{array}{l}\text { Results of Welch and Brown- } \\
\text { Forsythe robust F tests showed } \\
\text { that average number of downloads } \\
\text { did not vary across the types of } \\
\text { license and were not significant at } \\
\mathrm{p}<0.1 .\end{array}$ \\
\hline $\begin{array}{l}\text { Hypothesis 6b. Use of non- } \\
\text { restrictive license is positively } \\
\text { associated with the number of } \\
\text { releases of OSS projects. }\end{array}$ & Not supported & $\begin{array}{l}\text { In multivariate GLM the effect of } \\
\text { type of license on number of } \\
\text { releases is not significant because } \\
\text { Pillai's trace, Wilk's lambda, } \\
\text { Hotelling's trace, Roy's largest } \\
\text { root and F statistics for these are } \\
\text { not significant at } \mathrm{p}<0.1 . \\
\text { Therefore, average number of } \\
\text { releases did not vary across the } \\
\text { types of license. }\end{array}$ \\
\hline $\begin{array}{l}\text { Results of One-Way ANOVA test } \\
\text { showed that average number } \\
\text { releases did not vary across the } \\
\text { types of license and were } \\
\text { significant at } \mathrm{p}<0.1 .\end{array}$ \\
\hline
\end{tabular}




\section{DISCUSSION OF RESULTS}

This chapter discusses the results obtained in Chapter 5. It is organized into eight sections, each of which discusses a key finding from this research.

\subsection{OSS project success}

The success measures of OSS development projects seem to be different from those specified for development projects examined in the product development literature. According to Brown and Eisenhardt (1995), success of product development can be measured in terms of process efficiency and product effectiveness. Measures of process efficiency include development cost, development time, and engineering productivity. Measures of product effectiveness include sales revenue, profitability, and market share. According to Griffin and Page (1993), project success can be assessed using three dimensions: Customer-based success, financial success, and performance-based success. For most development projects, customer satisfaction and customer acceptance are two of the best measures of customer-based success. The degree to which profit goals are met may be an appropriate indicator of financial success. The degree to which a project provides a competitive advantage is the most useful indicator of performance-based success (Griffin and Page, 1996).

Success measures such as development cost, development time, engineering productivity, sales, profits and attainment of profit goals, customer satisfaction, market share, source of 
competitive advantage and other similar metrics are difficult to apply in the context of OSS projects. Other success measures are needed.

The results of an on line survey conducted to identify the measures of open source project success indicated that a majority of the developers that contribute to open source projects define success in terms of: number of users, number of downloads, and number of releases. Data on number of users is not publicly available. Thus, this research used number of downloads and number of releases as indicators of OSS project success.

\subsection{Factors that significantly affect OSS project success}

The results shown in Tables 9 and 34 suggest that the number of developers, experience of developers, target users type, software type, and development status significantly affect number of downloads and number of releases. Ranking the five independent variables that significantly affect the dependent variables using the Partial Eta squared coefficients shown in Table 9, provides the following results: 1. development status (.182 to .317$), 2$. software type $(0.022), 3$. experience of developers $(0.021), 4$. number of developers (0.019) and 5. targeting developers as users (0.014).

The ranking above suggests that:

- the effect of development status on number of downloads and number of releases is significant 
- software type, experience of developers, and number of developers affect number of downloads and number of releases more than user type targeted

\subsection{OSS projects that develop application development and deployment tools}

The results shown in Tables 9 and 34 support Hypotheses $5 \mathrm{a}$ and 5b. OSS projects that produce application development and deployment tools are more successful than OSS projects that produce application software and system infrastructure software.

According to Brown and Eisenhardt (1995), provision of unique benefits to customers is critical for the success of new product development. According to Crowston and Scozzi (2002), the OSS community is mostly comprised of user who have high software knowledge and can also develop software. OSS projects that address developers' needs for tools may be more successful than OSS projects that address the needs of end users and system administrators for application software and system infrastructure software.

\subsection{OSS projects that attract a greater number of experienced developers}

The results shown in Tables 9 and 34 support Hypotheses 1a, 1b, 2a and 2b. The number and experience of developers is positively associated with the success of OSS projects. To develop OSS successfully, the OSS project must motivate a large number of experienced developers to contribute to it. 
The number of developers has been identified as a factor that affects the success of OSS projects in the literature (Raymond, 1999; Crowston and Scozzi, 2002; Healy and Schussman, 2003; Duijnhouwer and Widdows, 2003). According to Raymond (1999), with more developers the rate of software development is increased. According to Crowston and Scozzi (2002) and Healy and Schussman (2003), OSS projects with more developers seem more successful. According to Duijnhouwer and Widdows (2003), the greater the number of developers that actively contribute to the OSS project, the smaller the likelihood that the OSS project will stall.

The literature has also reported that the greater the number of experienced developers the greater the likelihood that a development project will be successful. According to Healy and Schussman (2003), the experience of developers contributes to the success of OSS projects as well as conventional product development projects. Johne and Snelson (1988), Brown and Eisenhardt (1995), Storey and Easingwood, (1996), Carmel and Sawyer (1998), Curtis et al. (1988), Curtis (1981), Sheppard et al. (1979), and Krishnan (1998) emphasized that the experience of development teams is critical for the success of new product development. 


\subsection{OSS projects that target developers as users}

The results shown in Tables 9 and 34 indicate that OSS projects that target users who are developers are more successful. The more the users of the software look like the developers of the software, the greater the likelihood that the OSS project will be successful. This finding is consistent with the findings reported in the product development literature that the involvement of users in the product development process increases product success. According to Maidique and Zirger (1985), Cooper and Kleinschmidt (1987), Brown and Eisenhardt (1995), Thomke and von Hippel (2002), Callahan and Lasry (2004), and Christensen, Anthony, and Roth (2004), customer involvement in product development process is important for success.

\subsection{Factors that do not significantly affect OSS project success}

The results shown in Table 9 and 34 suggest that programming language type and OSS license type did not significantly affect the number of downloads and number of releases.

Hypotheses $4 \mathrm{a}$ and $4 \mathrm{~b}$ tested the relationship between the type of programming language used and the success of the OSS project. The rationale for Hypotheses $4 \mathrm{a}$ and $4 \mathrm{~b}$ was that developers will be concerned about the availability of the skills required to produce code. Therefore, OSS projects using a commonly used programming language may be more successful. 
A possible explanation for the results obtained could be that it may not be difficult for developers to learn new programming languages on their own if they are motivated to do so and have the basic programming skills already. If a developer is competent in a programming language, and if the OSS project addresses his/her needs, the developer will learn the new programming language.

Another explanation could be that a relatively crude measure was used to measure programming language type. Results could be different if more than two categories of the variable "programming language type" were used.

Hypotheses $6 \mathrm{a}$ and $6 \mathrm{~b}$ tested the relationship between the type of OSS license used and the success of OSS project. The results did not support the hypothesis that the use of nonrestrictive license is positively associated with the success of OSS projects. These results are not consistent with the findings of Fershtman and Gandal (2004) and Comino, Manenti, and Parisi (2005).

The development of Hypotheses $6 \mathrm{a}$ and $6 \mathrm{~b}$ was based on the rationale that open source products can choose from several different licenses. The choice made tell us the way in which intended users are approached and may affect the success of OSS project (Duijnhouwer and Widdows, 2003). License restrictiveness will be having negative effect on the popularity of open source software (Stewart, Ammeter, and Maruping, 2005). 
The finding that OSS license type does not affect success is not consistent with the findings of Fershtman and Gandal (2004) and Comino, Manenti, and Parisi (2005). Fershtman and Gandal (2004) found that the output per contributor of open source programs is much higher when licenses are less restrictive. Comino, Manenti, and Parisi (2005) found that the less restrictive the licensing terms the larger the likelihood of reaching an advanced development status, a measure of project success. A potential explanation for the discrepancy in findings is that this research used different measures of success than those used by Fershtman and Gandal (2004) and Comino, Manenti, and Parisi (2005).

\subsection{Development status affect factors-success relationship}

In this research, the development status of an OSS project was considered as an explanatory variable. The results in Table 9 indicated that the effect of development status on number of downloads and number of releases was significant. Development status provides information about the maturity of OSS projects. There are six development statuses specified for OSS projects on Sourceforge. These are: planning, pre-alpha, alpha, beta, production/stable, and mature. Each project registered on Sourceforge is classified into one of these six statuses by the developers of the software. No formal definitions of these stages are available on Sourceforge (Comino, Manenti, and Parisi, 2005). 


\subsection{Production/stable and mature OSS projects that develop application development and deployment tools}

In this research, the development status of an OSS project was considered as an explanatory variable. The results in Table 9 indicated that the effect of development status on number of downloads and number of releases was significant. Development status provides information about the maturity of OSS projects. There are six development statuses specified for OSS projects on Sourceforge. These are: planning, pre-alpha, alpha, beta, production/stable, and mature. Each project registered on Sourceforge is classified into one of these six statuses by the developers of the software. No formal definitions of these stages are available on Sourceforge (Comino, Manenti, and Parisi, 2005).

The results shown in Tables 37 and 55 suggest that OSS projects with a development status of production/stable or mature that produce application development and deployment tools are more successful than the OSS projects that produce application software and system infrastructure software. The only explanatory variable found to significantly affect OSS project success was software type. This is in contrast to the results shown in Tables 9 and 34 where software type, number of developers, experience of developers, and user type were found to affect OSS project success. The results when the sample is comprised of the 108 production/stable or mature OSS projects were found to be different from the results obtained when the sample is comprised of all 350 projects. 
A potential explanation for the difference may be that production/stable and mature OSS projects have attracted large numbers of experienced developers and users already.

Therefore, the type of software developed might be the only factor that distinguishes OSS project success when the OSS projects are production/stable or mature. 


\section{CONCLUSIONS, LIMITATIONS, AND SUGGESTIONS FOR FUTURE RESEARCH}

This chapter is organized into three sections. The first section provides the conclusions drawn from this research organized in two parts: i. key findings and ii. recommendations for people who set up and operate OSS projects and managers of development projects planning to incorporate open source into the company's products. The second section identifies the limitations of this research. Finally, the third section provides suggestions for future research.

\subsection{Conclusions}

The objective of this research was to identify the factors that contribute to the success of OSS projects measured as number of downloads and number of releases. The results of this research suggest that:

1. Developers who contribute to OSS projects define OSS project success in ways not traditionally used to measure the success of software development projects

2. Software type, experience of developers, and number of developers contribute to OSS project success more than does user targeted type

3. OSS projects that produce application development and deployment tools are more successful than OSS projects that produce application software and system infrastructure software 
4. OSS projects that attract a greater number of experienced developers are more successful

5. OSS projects that target developers as users are more successful

6. OSS projects that rely on commonly used programming languages and nonrestrictive software license are not more successful than other OSS projects

7. Development status affects the relationship between factors such as number of developers, experience of developers, target users type, and type of open source software developed, and the success of OSS projects

8. Production/stable and mature OSS projects that produce application development and deployment tools are most successful when success is measured as number of releases

Based on the results of this research recommendations can be made to individuals and organizations that set up and operate OSS projects as well as managers of development projects planning to incorporate open source into the company's products

Recommendations to the individuals and organizations that set up and operate OSS projects include:

- Establish mechanisms to motivate a large number of experienced developers to continuously contribute to the OSS project

- Attract experienced developers who will benefit most from advancing the OSS project 
- Target users who are themselves experienced developers and may benefit the most from using the OSS project

- Establish OSS projects that focus on application development and deployment tools

Recommendations to the managers of development projects planning to incorporate open source into the company's products include

- Use OSS projects that develop software which solves problems of both your target customers and target developers

- Hire developers with experience in the OSS projects in you wish to participate

- Target customers who are comfortable with the developers of the OSS project and stand to benefit the most from these developers' efforts

\subsection{Limitations}

The research is not without limitations. The first limitation is that the two measures of success used in this research are crude and have not been agreed to in the literature.

Second, while measuring the experience of developers of OSS projects, the profile of some developers was not accessible. For example, if a project had three developers it may be the case that the profile of one out of these three developers was not accessible. In 
these instance the approach used by the researcher to calculate the total experience of the three developers should be improved upon.

Third, this research has examined only a few of the many factors that may contribute to the success of OSS projects.

\subsection{Suggestions for future research}

There are three suggestions for future research. First, future research may consider the effect of other factors on the success of OSS development projects. The other factors that may be considered include: characteristics of the leaders and the communities that develop the OSS, software modularity, product complementarities, standard adoption, and ease of deployment (Duijnhouwer and Widdows, 2003).

Second, future research efforts may examine success measures other than number of downloads and number of releases. The other success measures that may be considered include: goal accomplishment, quality of code, need fulfillment, and user satisfaction, as mentioned by some respondents of online survey conducted by the researcher (Section 4.5.7).

Third, future research may examine the differences in the relationships between the factors examined in this research and measures of OSS project success across development statuses. 


\section{REFERENCES}

Bates, J., Wolf, B. \& Lakhani, K. R. (2002). The Boston Consulting Group hacker survey. http://www.ostg.com/bcg/BCGHACKERSURVEY-0.73.pdf (accessed February 1, 2006).

Bonaccorsi, A. \& Rossi, C. (2003). Comparing motivations of individual programmers and companies to take part in the Open Source movement. From community to business. Working paper, http://opensource.mit.edu/papers/bnaccorsirossimotivationlong.pdf (accessed February 1, 2006).

Brown, S. I. \& Eisenhardt, K. M. (1995). Product Development: Past Research, Present Findings and Future Directions. Academy of Management Review, 20(2): 343 378.

Callahan, J. \& Lasry, E. (2004). The Importance of Customer Input in the Development of Very New Products. $R \& D$ Management, 34(2): 107 - 120.

Carmel, E. \& Sawyer, S. (1998). Packaged software development teams: what makes them different? Information Technology and People, 11(1): 7-19. 
Christensen, C. M., Anthony, S. D., \& Roth, E. A. (2004). Seeing What's Next: Using the Theories of Innovation to Predict Industry Change: Harvard Business School Press, Boston, Massachusetts.

Comino, S., Manenti, F. M. \& Parisi, M. L. (2005). From Planning to Mature: on the Determinants of Open source Take Off. Working paper, Dipartimento di Scienze Economiche, Universita di Trento, Via Inama 5, 38100 TRENTO, Itally.

Cooper, R. G. \& Kleinschmidt, E. J. (1987). An Investigation into the New Product Process: Steps, Deficiencies, and Impact. Journal of Product Innovation Management, 3 : $71-85$.

Cooper, R. G. \& Kleinschmidt, E. J. (1987). Success Factors in Product innovation. Industrial Marketing Management, 16: 215-223.

Crowston, K., Annabi, H., \& Howison, J. (2003). Defining Open Source Software Project Success. Working paper, School of Information Studies, Syracuse University, Syracuse, NY USA.

Crowston, K., Annabi, H., Howison, J., \& Masango, C. (2004). Towards A Portfolio of FLOSS Project Success Measures. Working paper, School of Information Studies, Syracuse University, Syracuse, NY USA. 
Crowston, K. \& Scozzi, B. (2002). Open Source Software Projects as Virtual Organizations: Competency Rallying for Software Development. IEE Proceedings Software, 149(1): $3-17$.

Curtis, B. (1981). Substantiating programmer variability. Proceedings of IEEE, 69 (7): 846.

Curtis, B., Krasner, H. \& Iscoe, N. (1988). A field study of software design process for large systems. Coomunications of the ACM, 31(11): $1268-1287$.

Duijnhouwer, F. W. \& Widdows, C. (2003). Capgemini's Open Source Maturity Model http://www.seriouslyopen.org/nuke/html/modules/Downloads/osmm/GB_Expert_Letter Open_Source Maturity Model 1 1.5.3.pdf (accessed Feb 28, 2005).

Evers, S. (2000). An Introduction to Open Source Software Development. Working paper, Techniche Universitat Berlin.

Freshtman, C. \& Gandal, N. (2004). The Determinants of Output per Contributor in Open Source Projects: An Empirical Examination. CEPR Discussion paper, 4329

Gallivan, M. J. (2001). Striking a Balance Between Trust and Control in a Virtual Organization: A Content Analysis of Open Source Software Case Studies. Information Systems Journal, 11(4): $277-304$. 
Griffin, A. \& Page, A. L. (1993). An interim report on measuring product development success and failure. Journal of Product Innovation Management, 10: 291 - 308.

Ghosh, R. A., Glott, R., Krieger, B. \& Robles, G. (2002). Free/Libre and Open Source Software: Survey and Study. http://www.infonomics.nl/FLOSS/report/FLOSS_Final4.pdf (accessed February 1, 2006).

Griffin, A. \& Page, A. L. (1996). PDMA Success Measurement Project: Recommended Measures for Product Development Success and Failure. Journal of Product Innovation Management, 13(6): 478 - 496.

Healy, K. \& Schussman, A. (2003). The Ecology of Open-Source Software Development. Working paper, Department of Sociology, University of Arizona. http://www.opensource.mit.edu/papers/healyschussman.pdf (accessed March 10, 2005).

Hertel, G., Niedner, S. \& Herman, S. (2003). Motivation of Software Developers in the Open Source Projects: An Internet based Survey of Contributors to the Linux Kernel. Research Policy, 32(7): 1159 - 1177.

Johne, F. A. \& Snelson, P. A. (1988). Success factors in Product Innovation: A Selective Review of the Literature. Journal of Product Innovation Management, 5: 114 - 128. 
Koch, S. (2004). Profiling an Open Source Project Ecology and its Programmers. Electronic Markets, 14(2): 77 - 88.

Krishnan, M. S. (1998). The role of team factors in software cost and quality: An empirical analysis. Information Technology and People, 11(1): 20 - 35.

Lakhani, K. R., Wolf, B., Bates, J. \& DiBona, C. (2002). The Boston Consulting Group Hacker Survey. http://www.ostg.com/bcg (accessed Jan 31, 2006)

Lerner, J. \& Tirole, J. (2002). Some Simple Economics of Open Source. Journal of Industrial Economics, L (2): 197 - 234.

Lerner, J. \& Tirole, J. (2005). The Scope of Open Source Licensing. Journal of Law, Economics, \& Organization, 21(1): 20-56.

Maidique, M. A. \& Zirger, B. J. (1985). The New Product Learning Cycle. Research policy, 14(6): $299-313$.

Nissila, J. (2004). Towards a Better Understanding of Open Source Business Models. http://w3.msi.vxu.se/users/per/IRIS27/iris27-1202.pdf (accessed January 31, 2006).

O'Mahony, S. (2003). Guarding the Commons: How Community Managed Projects Protect their Work. Research Policy, 32: 1179 - 1198. 
Open Source Initiative. (2005). http://www.opensource.org (accessed Dec 7, 2005).

Page, A. L. (1993). Assessing New Product Development Practices and Performance:

Establishing Crucial Norms. Journal of product Innovation Management, 10: 273 - 290.

Paulson, J. W., Succi, G. \& Eberlein, A. (2004). An Empirical Study of Open Source and Closed Source Software Products. IEEE Transactions on Software Engineering, 30(4): $246-256$

Peng, Z. (2004). Linux Adoption by Firms. Thesis, Department of System and Computer Engineering, Carleton University, Ottawa.

Raymond, E. S. (1999). The Cathedral and the Bazaar, O'Reilly \& Associates, Sebastpol, CA.

Rossi, C. \& Bonaccorsi, A. (2005). Intrinsic vs. extrinsic incentives in profit-oriented firms supplying open source products and services.

http://www.firstmonday.org/issues/issue 10 5/rossi/\#note4 (accessed February 1, 2006).

Stewart, K. J., Ammeter, A. P. \& Maruping, L. M. (2005). A Preliminary Analysis of Licensing and Organizational Sponsorship on Success in Open Source Projects. Working paper, Proceedings of the $38^{\text {th }}$ Hawaii International conference on System Sciences $2005,1-10$. 
Storey, C. D. \& Easingwood, C. J. (1996). Determinants of new product performance: A study in the financial services sector. International Journal of Service Industry Management, 7(1): $32-55$.

Story, V., Smith, G. \& Saker, J. (2000). Developing Appropriate Measures of New Product Development: A Contingency-Based Approach. International Journal of Innovation Management, 5(1): $21-47$.

Thomke, S. \& von Hippel, E. (2002). Customers as Innovators: A New Way to Create Value. Harvard Business Review, 80(4): $74-81$.

von Krogh, G. \& von Hippel, E. (2003). Special issue on open source software development. Research Policy, 32 (7): 1149 - 1157.

West, J. \& S. O’Mahony (2005). Contrasting Community Building in Sponsored and Community Founded Open Source Projects.

http://opensource.mit.edu/papers/westomahony.pdf (accessed January 31, 2006).

Zhao, L. \& Elbaum, S. (2003). Quality Assurance under the Open Source Development Model. The Journal of Systems and Software, 66: 65 - 75.

Zirger, B. J. \& Maidique, M. A. (1990). A Model of New Product Development: An Empirical Test. Management Science, 36(7): 867 - 88 
Appendix A. List of projects in the sample

\begin{tabular}{|c|c|c|c|}
\hline S. No. & Project name & Web link & $\begin{array}{l}\text { Date of data } \\
\text { capturing }\end{array}$ \\
\hline 1 & Gaim & http://gaim.sourceforge.net & June 20, 2005 \\
\hline 2 & $\begin{array}{l}\text { SNAP Platform } \\
\text { and SNAPPIX }\end{array}$ & http://snapplatform.org/snappix/home & June 20,2005 \\
\hline 3 & PDFCreator & $\begin{array}{l}\text { http://sector7g.wurzel6.de/pdfcreator/index } \\
\text { _en.htm }\end{array}$ & June 20,2005 \\
\hline 4 & Complement & http://complement.sourceforge.net & June 20, 2005 \\
\hline 5 & MegaMek & $\begin{array}{l}\text { http://megamek.sourceforge.net/idx.php?p } \\
\mathrm{g}=\text { main }\end{array}$ & June 20,2005 \\
\hline 6 & $\begin{array}{l}\text { MinGW - } \\
\text { Minimalist GNU } \\
\text { for Windows }\end{array}$ & http://www.mingw.org & June 20,2005 \\
\hline 7 & PhpGedView & http://www.phpgedview.net & June 20,2005 \\
\hline 8 & PMD & http://pmd.sourceforge.net/ & June 21,2005 \\
\hline 9 & iTextSharp & http://itextsharp.sourceforge.net & June 21,2005 \\
\hline 10 & Fluxbox & http://fluxbox.sourceforge.net & June 21, 2005 \\
\hline 11 & The Mana World & http://themanaworld.org & June 21, 2005 \\
\hline
\end{tabular}




\begin{tabular}{|c|c|c|c|}
\hline 12 & csv2vcard & http://csv2vcard.sourceforge.net & June 21, 2005 \\
\hline 13 & IVI & http://ivi.sourceforge.net & June 21,2005 \\
\hline 14 & FreeCol & http://www.freecol.org & June 21, 2005 \\
\hline 15 & wxGlade & http://wxglade.sourceforge.net & June 21,2005 \\
\hline 16 & KFilm & http://kfilm.sourceforge.net & June 22,2005 \\
\hline 17 & VASSAL Engine & $\begin{array}{l}\text { http://www.vassalengine.org/community/in } \\
\text { dex.php }\end{array}$ & June 22, 2005 \\
\hline 18 & FreeMind & $\begin{array}{l}\text { http://freemind.sourceforge.net/wiki/index. } \\
\text { php/Main_Page }\end{array}$ & June 22, 2005 \\
\hline 19 & NeoBio & http://neobio.sourceforge.net & June 22, 2005 \\
\hline 20 & $\begin{array}{l}\text { jBpm.org - java } \\
\text { Business Process } \\
\text { Mgmt }\end{array}$ & http://www.jboss.com/products/jbpm & June 22, 2005 \\
\hline 21 & ShakesPeer & http://shakespeer.sourceforge.net & June 22, 2005 \\
\hline 22 & $\begin{array}{l}\text { Security Policy } \\
\text { Manager }\end{array}$ & http://iscs.sourceforge.net/ & June 23, 2005 \\
\hline 23 & Scintilla & http://www.scintilla.org & June 23,2005 \\
\hline 24 & quickplot & http://quickplot.sourceforge.net & June 23, 2005 \\
\hline
\end{tabular}




\begin{tabular}{|c|c|c|c|}
\hline 25 & $\begin{array}{l}\text { Linux Submarine } \\
\text { Simulation }\end{array}$ & http://www.linuxssn.org & June 23,2005 \\
\hline 26 & Slickworm & http://slickworm.sourceforge.net & June 23, 2005 \\
\hline 27 & $\begin{array}{l}\text { freeBASIC } \\
\text { Compiler }\end{array}$ & http://www.freebasic.net & June 23, 2005 \\
\hline 28 & PHPBalanceSheet & http://phpbalancesheet.sourceforge.net & June 23,2005 \\
\hline 29 & $\begin{array}{l}\mathrm{C} \text { and } \mathrm{C}++ \\
\text { Programming } \\
\text { Pearls }\end{array}$ & http://cpearls.sourceforge.net & June 23,2005 \\
\hline 30 & $\begin{array}{l}\text { QuickCam } \\
\text { Express Driver }\end{array}$ & http://qce-ga.sourceforge.net & June 23,2005 \\
\hline 31 & \begin{tabular}{|l} 
wxWidgets \\
(formerly \\
wxWindows)
\end{tabular} & http://wxwindows.org & June 24,2005 \\
\hline 32 & ndiswrapper & http://ndiswrapper.sourceforge.net & June 24,2005 \\
\hline 33 & $\begin{array}{l}\text { Multiple } \\
\text { Amusement/Gami } \\
\text { ng Emulator }\end{array}$ & http://magesrc.sourceforge.net/index.php & June 24,2005 \\
\hline 34 & $\begin{array}{l}\text { PHPeclipse - } \\
\text { PHP/SQL/HTML } \\
\text { Eclipse-Plugin }\end{array}$ & $\begin{array}{l}\text { http://www.phpeclipse.de/tiki- } \\
\text { view_articles.php }\end{array}$ & June 24,2005 \\
\hline 35 & JFreeChart & http://www.jfree.org/jfreechart/index.php & June 24,2005 \\
\hline
\end{tabular}




\begin{tabular}{|c|c|c|c|}
\hline 36 & Hibernate & http://www.hibernate.org & June 24,2005 \\
\hline 37 & UniParser toolkit & http://ex-code.com/uniparser & June 24,2005 \\
\hline 38 & Pitcher's Duel & http://pduel.sourceforge.net & June 24,2005 \\
\hline 39 & Topic Map API & http://tmapi.sourceforge.net & June 25,2005 \\
\hline 40 & EzSocket Library & http://ezsocket.sourceforge.net & June 25,2005 \\
\hline 41 & Think3D & http://think3d.sourceforge.net & June 25,2005 \\
\hline 42 & HTML Parser & http://htmlparser.sourceforge.net & June 25,2005 \\
\hline 43 & SQLiteManager & http://www.sqlitemanager.org & June 25,2005 \\
\hline 44 & $\begin{array}{l}\text { Spineless Game } \\
\text { Engine }\end{array}$ & http://spineless.sourceforge.net & June 26, 2005 \\
\hline 45 & $\begin{array}{l}\text { Neophyte Chess } \\
\text { Engine }\end{array}$ & http://neophyte.sourceforge.net & June 26, 2005 \\
\hline 46 & $\begin{array}{l}\text { Eclipse } \\
\text { Checkstyle Plug- } \\
\text { in }\end{array}$ & http://eclipse-cs.sourceforge.net & June 26,2005 \\
\hline 47 & $\begin{array}{l}\text { NuSOAP - SOAP } \\
\text { Toolkit for PHP }\end{array}$ & http://nusoap.sourceforge.net & June 26, 2005 \\
\hline 48 & DCRPG & http://dcnexusrpg.sourceforge.net & June 26,2005 \\
\hline
\end{tabular}




\begin{tabular}{|c|c|c|c|}
\hline 49 & Live Universe & http://letalka.sourceforge.net & June 26,2005 \\
\hline 50 & $\begin{array}{l}\text { Generic Model } \\
\text { Organism System } \\
\text { Database }\end{array}$ & http://www.gmod.org/node/86 & June 27,2005 \\
\hline 51 & JJPasswordSafe & http://jjpasswordsafe.sourceforge.net & June 27,2005 \\
\hline 52 & $\begin{array}{l}\text { Vesta } \\
\text { Configuration } \\
\text { Management } \\
\text { System }\end{array}$ & http://www.vestasys.org & June 27,2005 \\
\hline 53 & EclipseNSIS & http://eclipsensis.sourceforge.net & June 27,2005 \\
\hline 54 & xcrabble & http://xcrabble.sourceforge.net & June 27,2005 \\
\hline 55 & scooter & http://scooter.sourceforge.net & June 27, 2005 \\
\hline 56 & netatalk & http://netatalk.sourceforge.net & June 27,2005 \\
\hline 57 & $\begin{array}{l}\text { PN Web Ring } \\
\text { Module }\end{array}$ & http://www.ringlink.org & June 27,2005 \\
\hline 58 & UPC Database & http://www.upcdatabase.com & June 27,2005 \\
\hline 59 & Balder & http://balder.sourceforge.net & June 27,2005 \\
\hline 60 & $\begin{array}{l}\text { Ada } 95 \text { Appl. } \\
\text { Support } \\
\text { Component Lib. }\end{array}$ & http://ascl.sourceforge.net & June 27,2005 \\
\hline
\end{tabular}




\begin{tabular}{|c|c|c|c|}
\hline 61 & $\begin{array}{l}\text { Digital Paint } \\
\text { Paintball } 2\end{array}$ & $\begin{array}{l}\text { http://dynamic.gamespy.com/ digitalpaint/ } \\
\text { news.php }\end{array}$ & June 28,2005 \\
\hline 62 & ZX Box & http://zxbox.sourceforge.net & June 28,2005 \\
\hline 63 & PDFman & http://pdfman.sourceforge.net & June 28,2005 \\
\hline 64 & $\begin{array}{l}\text { Webmin System } \\
\text { stats }\end{array}$ & http://webminstats.sourceforge.net & June 28,2005 \\
\hline 65 & SystemImager & http://www.systemimager.org & June 28,2005 \\
\hline 66 & $\begin{array}{l}\text { WINE for Darwin } \\
\text { and Mac OS X }\end{array}$ & http://darwine.opendarwin.org & June 28,2005 \\
\hline 67 & $\begin{array}{l}\text { Dump/Restore } \\
\text { ext2/ext3 file } \\
\text { system backup }\end{array}$ & http://dump.sourceforge.net & June 29,2005 \\
\hline 68 & Inventory & http://inventory.sourceforge.net & June 29,2005 \\
\hline 69 & $\begin{array}{l}\text { jazzlib - a pure } \\
\text { java java.util.zip }\end{array}$ & http://jazzlib.sourceforge.net & June 29,2005 \\
\hline 70 & GFP & http://gfd.sourceforge.net & June 29,2005 \\
\hline 71 & mod_auth_mysql & http://modauthmysql.sourceforge.net & June 30,2005 \\
\hline 72 & $\begin{array}{l}\text { Anti-Spam SMTP } \\
\text { Proxy Server }\end{array}$ & http://assp.sourceforge.net & June 30,2005 \\
\hline 73 & CAD Toolkit & http://cadkit.sourceforge.net & June 30,2005 \\
\hline
\end{tabular}




\begin{tabular}{|c|c|c|c|}
\hline 74 & Webmin & http://www.webmin.com & June 30,2005 \\
\hline 75 & $\begin{array}{l}\text { DDD - Data } \\
\text { Display Debugger }\end{array}$ & http://www.gnu.org/software/ddd & July 1,2005 \\
\hline 76 & Visu & http://visu.sourceforge.net/home.en.html & July 1,2005 \\
\hline 77 & $\begin{array}{l}\text { Setserial --- serial } \\
\text { driver config tool }\end{array}$ & http://setserial.sourceforge.net & July 1,2005 \\
\hline 78 & FindBugs & http://setserial.sourceforge.net & July 1,2005 \\
\hline 79 & OpenC++ & http://opencxx.sourceforge.net & July 1,2005 \\
\hline 80 & phPhone & http://cmaser.sourceforge.net & July 1,2005 \\
\hline 81 & Xenocide & http://www.projectxenocide.com & July 1,2005 \\
\hline 82 & clib2 & http://clib2.sourceforge.net & July 2,2005 \\
\hline 83 & FreePOPs & http://www.freepops.org/en & July 2,2005 \\
\hline 84 & ARSperl & http://arsperl.sourceforge.net & July 2,2005 \\
\hline 85 & XPath Explorer & http://www.purpletech.com/xpe & July 2,2005 \\
\hline 86 & XBasic & http://xbasic.sourceforge.net & July 3,2005 \\
\hline 87 & strace & http://www.liacs.nl/ wichert/strace & July 3,2005 \\
\hline 88 & MoviX & http://movix.sourceforge.net & July 3,2005 \\
\hline
\end{tabular}




\begin{tabular}{|c|c|c|c|}
\hline 89 & $\begin{array}{l}\text { Modular } \\
\text { Controller } \\
\text { Architecture }\end{array}$ & http://mca2.sourceforge.net & July 3,2005 \\
\hline 90 & OpenFRAG & http://www.openfrag.org & July 3,2005 \\
\hline 91 & CivQuest & http://civquest.sourceforge.net & July 4,2005 \\
\hline 92 & lphantGUI & http://www.lphant.com & July 4,2005 \\
\hline 93 & Sync4j & http://www.funambol.com/opensource & July 4,2005 \\
\hline 94 & NiL Isn't Liero & http://nil.sourceforge.net & July 4,2005 \\
\hline 95 & $\begin{array}{l}\text { JSwat - Java } \\
\text { Debugger }\end{array}$ & http://jswat.sourceforge.net & July 4,2005 \\
\hline 96 & TeXnicCenter & $\begin{array}{l}\text { http://www.texniccenter.org/front_content. } \\
\text { php }\end{array}$ & July 4,2005 \\
\hline 97 & XPWeb & http://xpweb.sourceforge.net & July 4, 2005 \\
\hline 98 & Macattrick & http://www.macattrick.com & July 5,2005 \\
\hline 99 & XDoclet & $\begin{array}{l}\text { http://xdoclet.sourceforge.net/xdoclet/inde } \\
\text { x.html }\end{array}$ & July 5,2005 \\
\hline 100 & Wings 3D & http://www.wings3d.com & July 5,2005 \\
\hline 101 & AndyAdmin & http://andyadmin.sourceforge.net & July 11,2005 \\
\hline 102 & myIpacNG-stats & http://myipac-ng-stats.jems.de & July 11,2005 \\
\hline
\end{tabular}




\begin{tabular}{|c|c|c|c|}
\hline 103 & FProfiler & http://fprofiler.sourceforge.net & July 11,2005 \\
\hline 104 & $\begin{array}{l}\text { xacting form } \\
\text { validation service }\end{array}$ & http://xfvs.sourceforge.net & July 11,2005 \\
\hline 105 & $\begin{array}{l}\text { ClayTek 3D } \\
\text { Game Library \& } \\
\text { Editor }\end{array}$ & http://claytek.sourceforge.net & July 11,2005 \\
\hline 106 & ACMCo. KB & http://acmco-kb.sourceforge.net & July 11,2005 \\
\hline 107 & BuildBot & http://buildbot.sourceforge.net & July 12,2005 \\
\hline 108 & $\begin{array}{l}\text { Server Array } \\
\text { Management } \\
\text { System }\end{array}$ & http://project.antimatters.org.uk & July 12,2005 \\
\hline 109 & $\begin{array}{l}\text { Direct Show AC3 } \\
\text { Encoder }\end{array}$ & http://oss.netfarm.it & July 12,2005 \\
\hline 110 & $\begin{array}{l}\text { winadmin: } \\
\text { waUtils for } \\
\text { sysadmins }\end{array}$ & http://winadmin.sourceforge.net & July 12,2005 \\
\hline 111 & $\begin{array}{l}\text { LogQ Syslog } \\
\text { Query }\end{array}$ & http://logq.sourceforge.net & July 12,2005 \\
\hline 112 & nanoFTPd & http://nanoftpd.sourceforge.net & July 13,2005 \\
\hline 113 & cfGlitch & http://cfglitch.sourceforge.net & July 13,2005 \\
\hline 114 & Cute PHP library & $\begin{array}{l}\text { http://www.macher24.de/cphplib_english.h } \\
\text { tml }\end{array}$ & July 13,2005 \\
\hline
\end{tabular}




\begin{tabular}{|l|l|l|l|}
\hline 115 & $\begin{array}{l}\text { Compiere MFG }+ \\
\text { SCM } \\
\text { (Manufacturing) }\end{array}$ & http://compiere-mfgscm.sourceforge.net & July 13, 2005 \\
\hline 116 & $\begin{array}{l}\text { pacKAGE } \\
\text { oRGANIZER }\end{array}$ & http://paco.sourceforge.net & July 13, 2005 \\
\hline 117 & $\begin{array}{l}\text { JNetStream } \\
\text { Protocol Decoder }\end{array}$ & http://jnetstream.sourceforge.net & July 13, 2005 \\
\hline 118 & Remote-Serial & http://remote-serial.sourceforge.net & July 14, 2005 \\
\hline 119 & $\begin{array}{l}\text { NASA World } \\
\text { Wind }\end{array}$ & http://worldwind.arc.nasa.gov & July 14, 2005 \\
\hline 120 & IM Sniffer & http://im-snif.sourceforge.net & July 14, 2005 \\
\hline 121 & Ascent & http://ascent.sourceforge.net & July 14, 2005 \\
\hline 122 & Cajun & http://cajun.sourceforge.net & July 14, 2005 \\
\hline 123 & $\begin{array}{l}\text { OpenSharePoint } \\
\text { Team Service }\end{array}$ & http://opensharepoint.sourceforge.net & July 14, 2005 \\
\hline 124 & SharpFlash & http://sharpflash.sourceforge.net & July 15,2005 \\
\hline 126 & $\begin{array}{l}\text { SNTP Client for } \\
\text { Virtual PC }\end{array}$ & http://vsntp.sourceforge.net & Junsole 2005 \\
\hline 127 & http://stenil.sourceforge.net & huly \\
\hline
\end{tabular}




\begin{tabular}{|c|c|c|c|}
\hline 128 & Kalender & http://sourceforge.net/projects/mkal & July 15,2005 \\
\hline 129 & Swaret & http://swaret.sourceforge.net/index.php & July 15,2005 \\
\hline 130 & $\begin{array}{l}\text { Liberum Help } \\
\text { Desk }\end{array}$ & http://www.liberum.org & July 15,2005 \\
\hline 131 & $\begin{array}{l}\text { Modus } \\
\text { (ColdFusion } \\
\text { CMS framework) }\end{array}$ & http://modus.sourceforge.net & July 16,2005 \\
\hline 132 & Contact Manager & http://contact-manager.sourceforge.net & July 16,2005 \\
\hline 133 & $\begin{array}{l}\text { Automatic } \\
\text { Random } \\
\text { Signature } \\
\text { Generator }\end{array}$ & http://signify.sourceforge.net & July 16,2005 \\
\hline 134 & $\begin{array}{l}\text { tacacs++ server } \\
\text { daemon }\end{array}$ & http://sourceforge.net/projects/tacppd & July 16,2005 \\
\hline 135 & cpShuffleSature & http://cpshufflesature.sourceforge.net & July 16,2005 \\
\hline 136 & $\begin{array}{l}\text { Fwall - Linux } \\
\text { Firewall Script } \\
\text { Manager }\end{array}$ & http://fwall.sourceforge.net & July 16,2005 \\
\hline 137 & $\begin{array}{l}\text { mln - My Linux } \\
\text { Network UML } \\
\text { services }\end{array}$ & http://mln.sourceforge.net & July 16,2005 \\
\hline 138 & $\begin{array}{l}\text { VRRP - Virtual } \\
\text { Router } \\
\text { Redundancy } \\
\text { Protocol }\end{array}$ & http://www.imagestream.com/VRRP.html & July 16,2005 \\
\hline
\end{tabular}




\begin{tabular}{|c|c|c|c|}
\hline 139 & QJ-Pro & http://qjpro.sourceforge.net & July 17,2005 \\
\hline 140 & $\begin{array}{l}\text { Genesis3D Open } \\
\text { Source Project }\end{array}$ & http://www.genesis3d.com & July 17,2005 \\
\hline 141 & HTML Unit & http://htmlunit.sourceforge.net & July 17,2005 \\
\hline 142 & $\begin{array}{l}\text { phpMyEdit: } \\
\text { MySQL Table } \\
\text { Editor }\end{array}$ & http://www.phpmyedit.org & July 17,2005 \\
\hline 143 & CruiseControl & http://cruisecontrol.sourceforge.net & July 17,2005 \\
\hline 144 & $\begin{array}{l}\text { Java Persistent } \\
\text { Objects }\end{array}$ & http://www.jpox.org/index.jsp & July 18,2005 \\
\hline 145 & SpecTcl & http://spectcl.sourceforge.net & July 18,2005 \\
\hline 146 & StaloneTray & http://stalonetray.sourceforge.net & July 18,2005 \\
\hline 147 & $\begin{array}{l}\text { Jaluna Real-Time } \\
\text { Component Suite }\end{array}$ & http://sourceforge.net/projects/jaluna & July 18,2005 \\
\hline 148 & $\begin{array}{l}\text { Open Outlook } \\
\text { Connector }\end{array}$ & http://openconnector.org & July 19,2005 \\
\hline 149 & JAud & http://sourceforge.net/projects/jaud & July 19,2005 \\
\hline 150 & $\begin{array}{l}\text { Codebook } \\
\text { Framework for } \\
\text { Visual FoxPro }\end{array}$ & http://codebook.sourceforge.net & July 19,2005 \\
\hline 151 & Jajuk & http://jajuk.sourceforge.net & July 19,2005 \\
\hline 152 & $\begin{array}{l}\text { gv Postscript and } \\
\text { PDF viewer }\end{array}$ & http://www.gnu.org/software/gv & July 19,2005 \\
\hline
\end{tabular}




\begin{tabular}{|c|c|c|c|}
\hline 153 & $\begin{array}{l}\text { Linux layer } 7 \\
\text { packet classifier }\end{array}$ & http://17-filter.sourceforge.net & July 19,2005 \\
\hline 154 & MailManager & http://www.logicalware.org & July 19,2005 \\
\hline 155 & $\begin{array}{l}\text { Linux layer } 7 \\
\text { packet classifier }\end{array}$ & http://17-filter.sourceforge.net & July 20,2005 \\
\hline 156 & SystemImager & http://www.systemimager.org & July 20,2005 \\
\hline 157 & $\begin{array}{l}\text { AcidRip - a } \\
\text { Gtk2::Perl DVD } \\
\text { encoding GUI }\end{array}$ & http://untrepid.com/acidrip & July 20,2005 \\
\hline 158 & $\begin{array}{l}\text { MyBooking } \\
\text { System }\end{array}$ & http://mbsystem.sourceforge.net & Aug 6, 2005 \\
\hline 159 & $\begin{array}{l}\text { Creative Nomad } \\
\text { JukeBox } \\
\text { KIO::Slave }\end{array}$ & http://kionjb.sourceforge.net & Aug 6, 2005 \\
\hline 160 & qmatplot & http://qmatplot.sourceforge.net & Aug 6, 2005 \\
\hline 161 & Firestorm IDS & http://www.scaramanga.co.uk/firestorm & Aug 6, 2005 \\
\hline 162 & PEQ & http://www.projecteq.net & Aug 6, 2005 \\
\hline 163 & $\begin{array}{l}\text { Scorched Earth } \\
\text { Online War }\end{array}$ & http://seow.sourceforge.net & Aug 6, 2005 \\
\hline 164 & baiXa & http://baixa.sourceforge.net & Aug 6, 2005 \\
\hline
\end{tabular}




\begin{tabular}{|c|c|c|c|}
\hline 165 & $\begin{array}{l}\text { Smieciuch } \\
\text { Garbage } \\
\text { Collector }\end{array}$ & http://smieciuch.sourceforge.net & Aug 7, 2005 \\
\hline 166 & $\begin{array}{l}\text { Windows } \\
\text { Scancode } \\
\text { Interceptor }\end{array}$ & http://sourceforge.net/projects/wsi & Aug 7, 2005 \\
\hline 167 & $\mathrm{pMH}$ & http://phpmyhotels.sourceforge.net & Aug 7, 2005 \\
\hline 168 & xmltVR3 & http://xmltvr3.sourceforge.net & Aug 7, 2005 \\
\hline 169 & $\begin{array}{l}\text { Battle for } \\
\text { Wesnoth }\end{array}$ & http://www.wesnoth.org & Aug 8, 2005 \\
\hline 170 & JJPasswordSafe & http://jjpasswordsafe.sourceforge.net & Aug 8, 2005 \\
\hline 171 & SiGeFi & http://sourceforge.net/projects/sigefi & Aug 8, 2005 \\
\hline 172 & Bakefile & http://bakefile.sourceforge.net & Aug 8, 2005 \\
\hline 173 & Fields of Destiny & http://fod.sourceforge.net & Aug 8, 2005 \\
\hline 174 & $\begin{array}{l}\text { DELI: Delivery } \\
\text { context library }\end{array}$ & http://www.hpl.hp.com/personal/marbut & Aug 8, 2005 \\
\hline 175 & $\begin{array}{l}\text { Web PO } \\
\text { Requisition }\end{array}$ & http://sourceforge.net/projects/webprocure & Aug 9,2005 \\
\hline 176 & OpenXDK & http://www.openxdk.org & Aug 9, 2005 \\
\hline 177 & Genealogy & http://genealogy.sourceforge.net & Aug 9, 2005 \\
\hline
\end{tabular}




\begin{tabular}{|c|c|c|c|}
\hline 178 & Loki & http://erdani.org & Aug 9,2005 \\
\hline 179 & $\begin{array}{l}\text { Publicly } \\
\text { Available } \\
\text { PAssworDs }\end{array}$ & http://papad.sourceforge.net & Aug 9, 2005 \\
\hline 180 & $\begin{array}{l}\text { XML-RPC for } \\
\text { PHP }\end{array}$ & http://phpxmlrpc.sourceforge.net & Aug 9, 2005 \\
\hline 181 & py-icq & http://py-icq.sourceforge.net & Aug 9, 2005 \\
\hline 182 & $\begin{array}{l}\text { Tcl/Tk civserver } \\
\text { interface }\end{array}$ & http://civtk.sourceforge.net & Aug 10,2005 \\
\hline 183 & SDL.NET & $\begin{array}{l}\text { http://cs- } \\
\text { sdl.sourceforge.net/index.php/Main_Page }\end{array}$ & Aug 10, 2005 \\
\hline 184 & PerlGo & $\begin{array}{l}\text { http://dewarim.de/de/programme/go_en.ht } \\
\mathrm{ml}\end{array}$ & Aug 10, 2005 \\
\hline 185 & Atlantis Engine & http://atlantismmorpg.sourceforge.net & Aug 10, 2005 \\
\hline 186 & filewatcher & $\begin{array}{l}\text { http://www.willingminds.com/resources/fil } \\
\text { ewatcher.html }\end{array}$ & Aug 10, 2005 \\
\hline 187 & $\begin{array}{l}\text { Job Search } \\
\text { Management } \\
\text { Tool }\end{array}$ & http://jobhunt.sourceforge.net & Aug 10, 2005 \\
\hline 188 & $\begin{array}{l}\text { ebXML } \\
\text { Registry/Reposito } \\
\text { ry }\end{array}$ & http://ebxmlrr.sourceforge.net & Aug 10, 2005 \\
\hline
\end{tabular}




\begin{tabular}{|c|c|c|c|}
\hline 189 & The Dead Walk & http://thedeadwalk.zolton.org & Aug 10, 2005 \\
\hline 190 & $\begin{array}{l}\text { Vincent Mobile } \\
\text { 3D Rendering } \\
\text { Library }\end{array}$ & http://ogl-es.sourceforge.net/index.htm & Aug 10, 2005 \\
\hline 191 & Tortoise Mail & $\begin{array}{l}\text { http://tortoise- } \\
\text { mail.sourceforge.net/index.php?lng=en }\end{array}$ & Aug 11, 2005 \\
\hline 192 & $\begin{array}{l}\text { pastabrothers } \\
\text { pure-Linux }\end{array}$ & http://pure-linux.sourceforge.net & Aug 11, 2005 \\
\hline 193 & phpMyChord & http://phpmychord.sourceforge.net & Aug 11, 2005 \\
\hline 194 & Bacula & http://www.bacula.org & Aug 11, 2005 \\
\hline 195 & $\begin{array}{l}\text { gtk2hs: A Gtk2 } \\
\text { binding for } \\
\text { Haskell }\end{array}$ & http://haskell.org/gtk2hs & Aug 11, 2004 \\
\hline 196 & $\mathrm{rtEq}$ & http://rteq.sourceforge.net & Aug 11, 2005 \\
\hline 197 & $\begin{array}{l}\text { Extra Innings } \\
\text { Computer } \\
\text { Baseball }\end{array}$ & http://eicbaseball.sourceforge.net & Aug 12, 2005 \\
\hline 198 & Qsynth & $\begin{array}{l}\text { http://qsynth.sourceforge.net/qsynth- } \\
\text { index.html }\end{array}$ & Aug 12, 2005 \\
\hline 199 & Bomberman 3D & http://bomb3d.sourceforge.net & Aug 12, 2005 \\
\hline 200 & tkBoom & http://tkboom.sourceforge.net & Aug 12, 2005 \\
\hline
\end{tabular}




\begin{tabular}{|c|c|c|c|}
\hline 201 & MetaBoss & http://www.metaboss.com & Aug 12, 2005 \\
\hline 202 & $\begin{array}{l}\text { ContAuto - } \\
\text { Content } \\
\text { Automation }\end{array}$ & http://genmdixml.sourceforge.net & Aug 12, 2005 \\
\hline 203 & OpenBiblio & http://obiblio.sourceforge.net & Aug 12, 2005 \\
\hline 204 & Injection & http://injection.sourceforge.net & Aug 12, 2005 \\
\hline 205 & $\begin{array}{l}\text { Merchant of } \\
\text { Venus }\end{array}$ & http://win32dxproject.sourceforge.net & Aug 12, 2005 \\
\hline 206 & Karrigell & http://karrigell.sourceforge.net & Aug 12, 2005 \\
\hline 207 & Watermill & http://watermill.sourceforge.net & Aug 12, 2005 \\
\hline 208 & DJPlay & http://djplay.sourceforge.net & Aug 12, 2005 \\
\hline 209 & activ & http://activ.sourceforge.net & Aug 13, 2005 \\
\hline 210 & $\begin{array}{l}\text { Ozone - Java } \\
\text { OODBMS }\end{array}$ & $\begin{array}{l}\text { http://www.ozone- } \\
\text { db.org/frames/home/what.html }\end{array}$ & Aug 13, 2005 \\
\hline 211 & Nagat & http://nagat.sourceforge.net & Aug 13, 2005 \\
\hline 212 & MyUptime & http://myuptime.sourceforge.net & Aug 13, 2005 \\
\hline 213 & SoulCatcher & http://soulcatcher.sourceforge.net & Aug 13, 2005 \\
\hline 214 & $\begin{array}{l}\text { ADnD Simple } \\
\text { Character }\end{array}$ & http://ascg.sourceforge.net & Aug 13, 2005 \\
\hline
\end{tabular}




\begin{tabular}{|c|c|c|c|}
\hline & Generator & & \\
\hline 215 & $\begin{array}{l}\text { LXR Cross } \\
\text { Referencer }\end{array}$ & http://1xr.sourceforge.net & Aug 13,2005 \\
\hline 216 & Knights & http://www.knights-chess.com & Aug 13,2005 \\
\hline 217 & Fields of Destiny & http://fod.sourceforge.net & Aug 13, 2005 \\
\hline 218 & XINS & http://xins.sourceforge.net & Aug 13, 2005 \\
\hline 219 & Observ & http://observ.sourceforge.net & Aug 13, 2005 \\
\hline 220 & Elephant Memory & http://reminder.sourceforge.net/ & Aug 14, 2005 \\
\hline 221 & logisim & http://logisim.sourceforge.net & Aug 14, 2005 \\
\hline 222 & Karrigell & http://karrigell.sourceforge.net & Aug 14,2005 \\
\hline 223 & $\begin{array}{l}\text { BC } \\
\text { Glyphgenerator }\end{array}$ & http://www.bravecobra.com & Aug 14, 2005 \\
\hline 224 & SageTV Plugins & http://sageplugins.sourceforge.net & Aug 14, 2005 \\
\hline 225 & Immortal Pongbat & http://pongbat.sourceforge.net & Aug 14, 2005 \\
\hline 226 & Spago & http://spago.eng.it/docs_en/index.html & Aug 14, 2005 \\
\hline 227 & Vade Mecum & http://vade-mecum.sourceforge.net & Aug 14, 2005 \\
\hline 228 & utPLSQL & http://utplsql.sourceforge.net & Aug 14, 2005 \\
\hline
\end{tabular}




\begin{tabular}{|c|c|c|c|}
\hline 229 & Open Job Control & http://openjc.sourceforge.net & Aug 15,2005 \\
\hline 230 & Fudaa & http://fudaa.sourceforge.net & Aug 15, 2005 \\
\hline 231 & $\begin{array}{l}\text { Kricketscoreboar } \\
\text { d }\end{array}$ & http://kricketsb.sourceforge.net & Aug 15,2005 \\
\hline 232 & Eucalyptus & http://eucalyptus.sourceforge.net & Aug 15,2005 \\
\hline 233 & $\begin{array}{l}\text { libMesh: A C++ } \\
\text { Finite Element } \\
\text { Library }\end{array}$ & http://libmesh.sourceforge.net & Aug 15,2005 \\
\hline 234 & GISAR & $\begin{array}{l}\text { http://gisar.sourceforge.net/ENG/Index.ht } \\
\mathrm{m}\end{array}$ & Aug 15,2005 \\
\hline 235 & GTK+ Mac OS X & http://gtk-osx.sourceforge.net & Aug 15, 2005 \\
\hline 236 & BooLogic & http://boologic.sourceforge.net & Aug 16,2005 \\
\hline 237 & HAPI & http://hl7api.sourceforge.net & Aug 16,2005 \\
\hline 238 & SCMxx & http://www.hendrik-sattler.de/scmxx & Aug 16,2005 \\
\hline 239 & $\begin{array}{l}\text { GenetX } \\
\text { Configurator }\end{array}$ & http://gxconf.sourceforge.net & Aug 16,2005 \\
\hline 240 & $\begin{array}{l}\text { MIDAS Network } \\
\text { Monitoring } \\
\text { Server }\end{array}$ & http://midas-nms.sourceforge.net & Aug 16,2005 \\
\hline
\end{tabular}




\begin{tabular}{|c|c|c|c|}
\hline 241 & SISC & http://sisc.sourceforge.net & Aug 16, 2005 \\
\hline 242 & $\begin{array}{l}\text { LilyPondTool for } \\
\text { JEdit }\end{array}$ & http://lily4jedit.sourceforge.net & Aug 16, 2005 \\
\hline 243 & $\begin{array}{l}\text { The Virtuality } \\
\text { Renderer }\end{array}$ & http://virtuality.sourceforge.net & Aug 16,2005 \\
\hline 244 & $\begin{array}{l}\text { Danger from the } \\
\text { Deep }\end{array}$ & http://dangerdeep.sourceforge.net & Aug 16, 2005 \\
\hline 245 & Gnome Pokies & http://gpokies.sourceforge.net & Aug 17, 2005 \\
\hline 246 & Turbo Vision & http://tvision.sourceforge.net & Aug 17, 2005 \\
\hline 247 & $\begin{array}{l}\text { GNU/Linux } 1394 \\
\text { AV/C Library }\end{array}$ & http://libavc1394.sourceforge.net & Aug 17, 2005 \\
\hline 248 & SibylSQL & $\begin{array}{l}\text { http://www.nightstarcorporation.com/oss/si } \\
\text { bylsql }\end{array}$ & Aug 17, 2005 \\
\hline 249 & Boson & http://boson.eu.org & Aug 17, 2005 \\
\hline 250 & $\begin{array}{l}\text { Serial Gaming } \\
\text { Network Daemon }\end{array}$ & http://sgnetd.sourceforge.net & Aug 17, 2005 \\
\hline 251 & $\begin{array}{l}\text { Muttprint -- } \\
\text { Pretty Printing } \\
\text { Your eMails }\end{array}$ & http://muttprint.sourceforge.net & Aug 18, 2005 \\
\hline 252 & ECB & http://ecb.sourceforge.net & Aug 18, 2005 \\
\hline 253 & $\begin{array}{l}\text { sql-characteristic- } \\
\text { functions }\end{array}$ & http://sqlchar.sourceforge.net & Aug 18,2005 \\
\hline
\end{tabular}




\begin{tabular}{|c|c|c|c|}
\hline 254 & Open SONG db & http://songdb.sourceforge.net & Aug 18,2005 \\
\hline 255 & PacketFence & http://www.packetfence.org & Aug 18,2005 \\
\hline 256 & Emilda & http://www.emilda.org & Aug 18,2005 \\
\hline 257 & Visual-MinGW & http://visual-mingw.sourceforge.net & Aug 18, 2005 \\
\hline 258 & Light up X & $\begin{array}{l}\mathrm{http}: / / \text { www.theaterzentrum.at/technix/devel } \\
\text { opment/lux }\end{array}$ & Aug 18, 2005 \\
\hline 259 & Memoranda & http://memoranda.sourceforge.net & Aug 18,2005 \\
\hline 260 & $\begin{array}{l}\text { Project JEDI API } \\
\text { Library }\end{array}$ & http://jedi-apilib.sourceforge.net & Aug 18,2005 \\
\hline 261 & Iequalsi & http://iequalsi.sourceforge.net & Aug 18, 2005 \\
\hline 262 & Antenna & http://antenna.sourceforge.net & Aug 18,2005 \\
\hline 263 & $\begin{array}{l}\text { Windows } \\
\text { Unattended } \\
\text { Install Web GUI }\end{array}$ & http://winunattended.sourceforge.net & Aug 18, 2005 \\
\hline 264 & Atlas & $\mathrm{http} / / /$ atlas.sourceforge.net & Aug 18, 2005 \\
\hline 265 & $\begin{array}{l}\text { iBATIS.NET } \\
\text { DataMapper }\end{array}$ & http://ibatis.apache.org & Aug 18, 2005 \\
\hline 266 & Linuxdiagnosis & $\begin{array}{l}\text { http://digilander.libero.it/_ppricerca/index. } \\
\text { html }\end{array}$ & Aug 18, 2005 \\
\hline 267 & Phoenix Mail & http://phxmail.sourceforge.net & Aug 19, 2005 \\
\hline
\end{tabular}




\begin{tabular}{|l|l|l|l|}
\hline 268 & Pop-Up Buster & http://pobu.sourceforge.net & Aug 19, 2005 \\
\hline 269 & poEdit & http://www.poedit.org & Aug 19, 2005 \\
\hline 270 & Xbgm & http://xbgm.sourceforge.net & Aug 19, 2005 \\
\hline 271 & Rolf & http://sourceforge.net/projects/rolf & Aug 19, 2005 \\
\hline 272 & $\begin{array}{l}\text { Iter Vehemens ad } \\
\text { Necem }\end{array}$ & http://ivan.sourceforge.net & Aug 19, 2005 \\
\hline 273 & qmatplot & http://qmatplot.sourceforge.net & Aug 19, 2005 \\
\hline 274 & $\begin{array}{l}\text { Ethernut } \\
\text { Embedded } \\
\text { Ethernet }\end{array}$ & http://www.ethernut.de/en/index.html & Aug 20, 2005 \\
\hline 275 & NukeTreasury & http://nuketreasury.sourceforge.net & Aug 20, 2005 \\
\hline 276 & Nanashi & http://nanashi.sourceforge.net & Aug 20, 2005 \\
\hline 277 & WinSTB & http://winstb.sourceforge.net/index-en.htm & Aug 21, 2005 \\
\hline 279 & $\begin{array}{l}\text { BACnet Protocol } \\
\text { Stack }\end{array}$ & http://bacnet.sourceforge.net & Aug 22, 2005 \\
\hline
\end{tabular}




\begin{tabular}{|c|c|c|c|}
\hline & (ACL) project & & \\
\hline 282 & Archetypes & http://plone.org/products/archetypes & Aug 22, 2005 \\
\hline 283 & TclAddressBook & $\begin{array}{l}\text { http://webperso.easyconnect.fr/bdesgraupe } \\
\text { s/DocHTML/TclAB.html }\end{array}$ & Aug 22, 2005 \\
\hline 284 & $\begin{array}{l}\text { Symbian OS C++ } \\
\text { Unit Testing } \\
\text { Framework }\end{array}$ & http://www.symbianosunit.co.uk & Aug 22, 2005 \\
\hline 285 & $\begin{array}{l}\text { Fisterra GNOME } \\
\text { development } \\
\text { framework }\end{array}$ & $\begin{array}{l}\text { http://community.igalia.com/twiki/bin/vie } \\
\text { w/Fisterra }\end{array}$ & Aug 23, 2005 \\
\hline 286 & JetStyle & http://jetstyle.sourceforge.net & Aug 23, 2005 \\
\hline 287 & Middle Haven & http://middle-haven.sourceforge.net & Aug 23,2005 \\
\hline 288 & $\begin{array}{l}\text { CryptNET Key } \\
\text { Server }\end{array}$ & http://cryptnet.net/fsp/cks & Aug 23, 2005 \\
\hline 289 & $\begin{array}{l}\text { Auto } \\
\text { MySqlBackup }\end{array}$ & http://autobackup.sourceforge.net & Aug 23, 2005 \\
\hline 290 & FreeWPS $[\mathrm{tm}]$ & http://www.ytztech.com/freewps & Aug 23, 2004 \\
\hline 291 & $\begin{array}{l}\text { Videotron Cable } \\
\text { Modem Usage }\end{array}$ & http://vemu.sourceforge.net & Aug 23, 2005 \\
\hline 292 & Tourney Tracker & http://fighttracker.sourceforge.net & Aug 24, 2005 \\
\hline 293 & JET-Editor & http://jet-editor.sourceforge.net & Aug 24,2005 \\
\hline
\end{tabular}




\begin{tabular}{|c|c|c|c|}
\hline 294 & SmartWin++ & http://smartwinlib.org & Aug 24, 2005 \\
\hline 295 & SkyEye & http://www.skyeye.org/index.shtml & Aug 24, 2005 \\
\hline 296 & $\begin{array}{l}\text { Simple } \\
\text { Addressbook }\end{array}$ & http://polarisun.sourceforge.net & Aug 25,2005 \\
\hline 297 & $\begin{array}{l}\text { Quick Dungeons } \\
\text { and Dragons }\end{array}$ & http://qd-d.sourceforge.net & Aug 25,2005 \\
\hline 298 & StarFrag & http://starfrag.sourceforge.net & Sep 1, 2005 \\
\hline 299 & AGKit & http://agkit.sourceforge.net & Sep 1, 2005 \\
\hline 300 & Jena & http://jena.sourceforge.net & Sep 1, 2005 \\
\hline 301 & Devil-Linux & $\begin{array}{l}\text { http://www.devil- } \\
\text { linux.org/home/index.php }\end{array}$ & Sep 2, 2005 \\
\hline 302 & OpenSMART & http://opensmart.sourceforge.net & Sep 2, 2005 \\
\hline 303 & $\begin{array}{l}\text { WEB-DAV } \\
\text { Linux File } \\
\text { System(davfs) }\end{array}$ & http://dav.sourceforge.net & Sep 2, 2005 \\
\hline 304 & $\begin{array}{l}\text { OpenSharePoint } \\
\text { Team Service }\end{array}$ & http://opensharepoint.sourceforge.net & Sep 3, 2005 \\
\hline 305 & mailscanner-mrtg & http://mailscannermrtg.sourceforge.net & Sep 4, 2005 \\
\hline 306 & Weplab & http://weplab.sourceforge.net & Sep 4, 2005 \\
\hline 307 & IP traffic volume & http://iptrafficvolume.sourceforge.net & Sep 5,2005 \\
\hline
\end{tabular}




\begin{tabular}{|c|c|c|c|}
\hline & logger & & \\
\hline 308 & $\begin{array}{l}\text { vpopmail - virtual } \\
\text { domains for qmail }\end{array}$ & $\begin{array}{l}\text { http://www.inter7.com/index.php?page=vp } \\
\text { opmail }\end{array}$ & Sep 5, 2005 \\
\hline 309 & $\begin{array}{l}\text { Port Forwarding } \\
\text { Daemon }\end{array}$ & http://portfwd.sourceforge.net & Sep 7, 2005 \\
\hline 310 & $\begin{array}{l}\text { Linux Trustees } \\
\text { (ACL) project }\end{array}$ & http://trustees.aeruder.net & Sep 7, 2005 \\
\hline 311 & $\begin{array}{l}\text { winadmin: } \\
\text { waUtils for } \\
\text { sysadmins }\end{array}$ & http://winadmin.sourceforge.net & Sep 11,2005 \\
\hline 312 & $\begin{array}{l}\text { JNetStream } \\
\text { Protocol Decoder }\end{array}$ & http://jnetstream.sourceforge.net & Sep 11,2005 \\
\hline 313 & Ddclient & http://ddclient.sourceforge.net & Sep 16, 2005 \\
\hline 314 & simpleproxy & http://www.crocodile.org/software.html & Sep 16, 2005 \\
\hline 315 & $\begin{array}{l}\text { Enterprise } \\
\text { Diskspace } \\
\text { Monitoring } \\
\text { System }\end{array}$ & http://edimos.sourceforge.net/ & Sep 16,2005 \\
\hline 316 & 12tpns & http://sourceforge.net/projects/12tpns & Sep 16, 2005 \\
\hline 317 & zmod-stats & http://zmod-stats.sourceforge.net & Sep 17, 2005 \\
\hline 318 & get_xyz & http://get-xyz.sourceforge.net & Sep 17, 2005 \\
\hline
\end{tabular}




\begin{tabular}{|c|c|c|c|}
\hline 319 & CaiCai & http://caicai.sourceforge.net & Sep 17, 2005 \\
\hline 320 & $\begin{array}{l}\text { Patch Integration } \\
\text { Engine (PIE) }\end{array}$ & http://pie.sourceforge.net & Sep 20, 2005 \\
\hline 321 & $\begin{array}{l}\text { Ida - Intrusion } \\
\text { Detection for } \\
\text { Apache }\end{array}$ & http://phpida.sourceforge.net & Sep 21, 2005 \\
\hline 322 & $\begin{array}{l}\text { The GNU Recipe } \\
\text { Database }\end{array}$ & http://grdb.sourceforge.net & Sep 21, 2005 \\
\hline 323 & $\begin{array}{l}\text { lemonldap } \\
\text { reverse proxy }\end{array}$ & http://lemonldap.sourceforge.net & Sep 21, 2005 \\
\hline 324 & JOPAC2 & http://jopac2.sourceforge.net/html & Sep 22, 2005 \\
\hline 325 & $\begin{array}{l}\text { LAN-party Web } \\
\text { Portal System }\end{array}$ & http://osglobelan.sourceforge.net & Sep 22, 2005 \\
\hline 326 & $\begin{array}{l}\text { RH Domain } \\
\text { Controller }\end{array}$ & http://rhems.sourceforge.net & Sep 22, 2005 \\
\hline 327 & Cricket & http://cricket.sourceforge.net & Sep 22, 2005 \\
\hline 328 & IlohaMail & http://blog.ilohamail.org & Sep 23, 2005 \\
\hline 329 & mod_cas & http://mod-cas.sourceforge.net & Sep 23, 2005 \\
\hline 330 & $\begin{array}{l}\text { Password } \\
\text { Management } \\
\text { System }\end{array}$ & $\begin{array}{l}\text { http://www.harry- } \\
\text { b.de/dokuwiki/doku.php?id=harry:cpm }\end{array}$ & Sep 23, 2005 \\
\hline
\end{tabular}




\begin{tabular}{|c|c|c|c|}
\hline 331 & vuser & http://sourceforge.net/projects/vuser & Sep 25, 2005 \\
\hline 332 & AirSnort & http://airsnort.shmoo.com & Sep 25,2005 \\
\hline 333 & HotSaNIC & http://hotsanic.sourceforge.net & Sep 25, 2005 \\
\hline 334 & ATM on Linux & http://linux-atm.sourceforge.net & Sep 25, 2003 \\
\hline 335 & $\begin{array}{l}\text { Java } \\
\text { SMTP/POP/WEB } \\
\text { EMail Server }\end{array}$ & $\begin{array}{l}\text { http://www.ericdaugherty.com/java/mailser } \\
\text { ver }\end{array}$ & Sep 26, 2005 \\
\hline 336 & album.php & http://perl.bobbitt.ca/album & Sep 26, 2005 \\
\hline 337 & $\begin{array}{l}\text { CybOrg. The } \\
\text { CyberCafe } \\
\text { Organizer }\end{array}$ & http://cyborg.sourceforge.net/index.html.en & Sep 26, 2005 \\
\hline 338 & $\begin{array}{l}\text { MIDAS Network } \\
\text { Monitoring } \\
\text { Server }\end{array}$ & http://midas-nms.sourceforge.net & Sep 27, 2005 \\
\hline 339 & Pagetool & http://www.pagetool.org & Sep 27, 2005 \\
\hline 340 & Nagat & http://nagat.sourceforge.net & Sep 27, 2005 \\
\hline 341 & FAQ-O-Matic & $\begin{array}{l}\text { http://faqomatic.sourceforge.net/fom- } \\
\text { serve/cache/1.html }\end{array}$ & Sep 28, 2005 \\
\hline 342 & $\begin{array}{l}\text { BPF traffic } \\
\text { daemon/collector }\end{array}$ & http://bpft4.sourceforge.net & Sep 29, 2005 \\
\hline
\end{tabular}




\begin{tabular}{|l|l|l|l|}
\hline 343 & $\begin{array}{l}\text { LeagueSite - } \\
\text { Sports } \\
\text { Team/League } \\
\text { CMS }\end{array}$ & http://leaguesite.sourceforge.net & Sep 30, 2005 \\
\hline 344 & $\begin{array}{l}\text { System } \\
\text { Configurator }\end{array}$ & http://wiki.sisuite.org/SystemConfigurator & Sep 30, 2005 \\
\hline 345 & Minerva & http://minerva.sourceforge.net & Sep 30, 2005 \\
\hline 346 & $\begin{array}{l}\text { PerfParse } \\
\text { http://perfparse.sourceforge.net }\end{array}$ & Oct 1,2005 \\
\hline 347 & $\begin{array}{l}\text { OpenVMPS } \\
\text { Oiberum Help } \\
\text { Desk }\end{array}$ & http://vmps.sourceforge.net & Oct 1, 2005 \\
\hline 349 & $\begin{array}{l}\text { Nagios Plugins } \\
\text { and Extensions }\end{array}$ & http://nwwlax.sourceforge.net & Oct 1, 2005 \\
\hline 350 & $\begin{array}{l}\text { Wree WiFi Web } \\
\text { Interface }\end{array}$ & http://wifiadmin.sourceforge.net & Oct 1, 2005 \\
\hline
\end{tabular}

